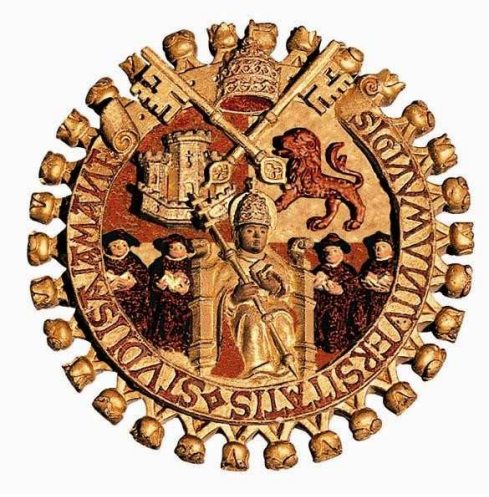

UNIVERSITY OF SALAMANCA

\title{
Angiogenic and antiangiogenic factors in diseases due to helminths
}

Ph.D Thesis

Fariborz Shariati Sharifi

Department of Animal Biology, Parasitology, Ecology and Soil Science-Agricultural Chemistry 


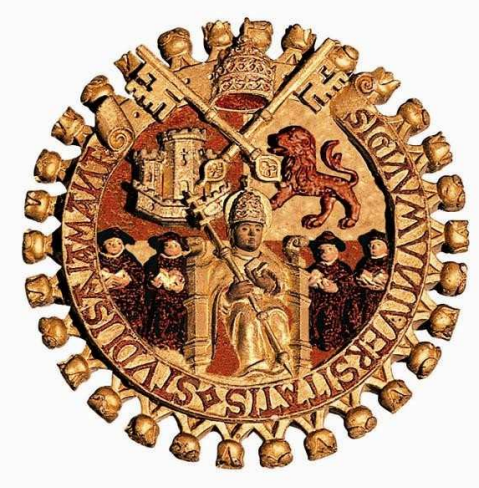

UNIVERSDAD DE SALAMANCA

\section{Factores angiogénicos y antiangiogénicos en helmintosis}

Ph.D Thesis

Memoria que presenta Fariborz Shariati Sharifi para optar al grado de doctor

Departamento de Biología Animal, Parasitología, Ecología y Edafología-Química Agrícola. 
Prof. Dr. Antonio Muro Álvarez Professor of the Faculty of Pharmacy at the Department of Animal Biology, Parasitology, Ecology and Soil Science-Agricultural Chemistry at University of Salamanca and Director of the Research Center of Tropical Diseases of the University of Salamanca (CIETUS). and Prof. Dr José Luís Pérez Arellano Professor of the Faculty of Health Sciences, of the Department of Medical and Surgical Sciences of the University of Las Palmas de Gran Canaria. Director of the Tropical Medicine Unit of Las Palmas Insular Hospital.

Certify, that the present dissertation entitled "Angiogenic and antiangiogenic factors in diseases due to helminths" submitted to apply for $\mathrm{PhD}$ degree has been carried out by Fariborz Shariati Sharifi under our direction in the Department of Animal Biology, Parasitology, Ecology and Soil Science-Agricultural Chemistry, University of Salamanca, we considered that this dissertation comply the necessary requirements to be evaluated.

Disertation presented by Fariboz Shariati Sharifi for obtainig the $\mathrm{PhD}$ degree. 
Prof. Dr. Antonio Muro Álvarez, Catedrático de la Facultad de Farmacia, del Departamento de Biología Animal, Parasitología, Ecología y Edafología-Química Agrícola y Director del Centro de Investigación de Enfermedades Tropicales de la Universidad de Salamanca (CIETUS). Prof. Dr José Luís Pérez Arellano, Profesor de la Facultad de Ciencias de Salud, del Departamento de Ciencias Médicas y Quirúrgicas Las Palmas de Gran Canaria y Director de la Unidad de Medicina Tropical del Hospital Insular de las Palmas

Certifican que la presente Tesis Doctoral titulada "Factores angiogénicos y antiangiogénicos en helmintosis" que se presenta para optar al grado de Doctor por la Universidad de Salamanca ha sido realizada por Fariborz Shariti Sharifi bajo nuestra dirección el departamento de Departamento de Biología Animal, Parasitología, Ecología y Edafología-Química Agrícola de la Universidad, consideramos que reune los requisitos necesarios por lo que autorizamos su presentación para ser evaluada.

Tesis Doctoral presentado por Fariboz Shariati Sharifi para la obtención del Grado de Doctor por la Universidad de Salamanca 
By time, Indeed mankind is in loss. Except for those who have believed and Done righteous deeds and advise each other To truth and advise each other to patience. (Holy Qur'an)

To My family

\section{Maryam, my sons Amir and Shervin}

That has been my pillar of support. I could not have completed this degree without their love, help, understanding and encouragement.

I regret my father did not live long enough to see me receive this degree.

I thank my mother for her support and for taking my answers for her favourite question "when are you going to come back?" with a good sense of humour. 
I would like to thank my main supervisor Antonio Muro Alvarez for giving me the possibility to join his lab. I am grateful for his support and confidence as well as for giving me the opportunity to participate in national and international conferences, which allowed me to get more insight into the world of research. I would also like to thank him for his patience with reviewing the articles and this thesis over and over again.

I am also deeply grateful to my second supervisor José Luís Pérez Arellano for encouragement and for the critical review of articles and design all experiments. If graduate students have to be lucky to get a good advisor, then I am the luckiest person, as I have two great advisors. They have been more than research advisors to me, and I greatly benefited from their teaching, advice and guidance on a number of academic, professional and career choices.

I address my warm thanks to Julio Lopez Abán for persistently organizing the in vivo experiment and all the statistic programs for this thesis.

I am also grateful to Dr Antonio Martínez Fernández for his guidance and preparing antigens of Trichinella spiralis. I am grateful to Dr Dunne and Dr Mike Doenhoff for their guidance and preparing antigens of Schistosoma mansoni. I express my sincere gratitude to Dr Zhenfan Yang for consult and good suggestion about the VEGF and also thanks to Dr Jyo shiro about helpful guide of determination of FGF-2.

I am deeply grateful to all my former and current colleagues at the department of Parasitology for their unforgettable companionship and for the interesting scientific and unscientific conversations during these years: Belén, Rodrigo, Pedro, Edward, Amparo, Ahmed, Johny, Carmen, Luis, Juan, Javier, Jose Vicente, Rubén, Ondra and María.

I would also like to thank Gwyn Jenkins for his help to write article in English, much more for correction of articles.

Thanks are also due to the stuff members of faculty of Pharmacy, animal house of the University of Salamanca and Teresa secretary of the Department.

Finally I deeply thank people of Spain specially people of Salamanca for good fellowship and be kindness with me and my family and I remember them for ever. 
Fariborz Shariati Sharifi had a doctoral fellowship from the Ministery of Science and Technology or Islamic Republic of Iran

This work was supported by the project of Junta de Castilla y León, Spain SA116A08 and Research Center of Tropical Diseases of the Universitiy of Salamanca (CIETUS). 


\section{Table of contens}

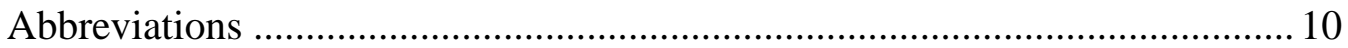

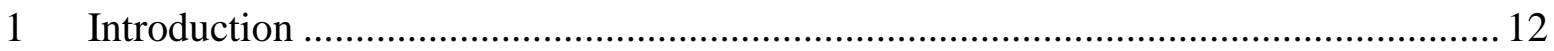

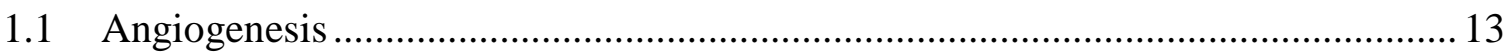

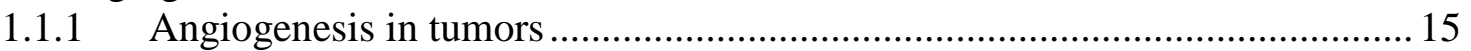

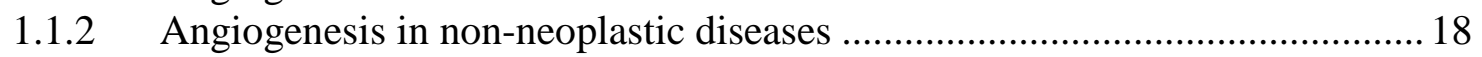

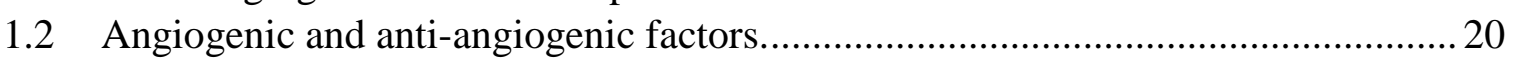

1.2.1 Vascular Endothelial Growth Factor (VEGF) .......................................... 20

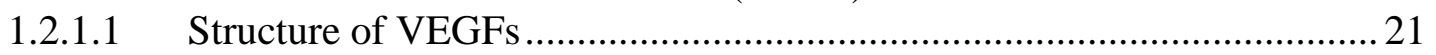

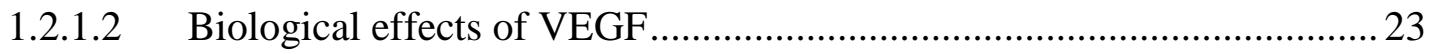

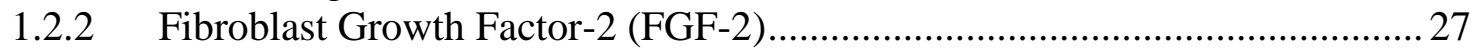

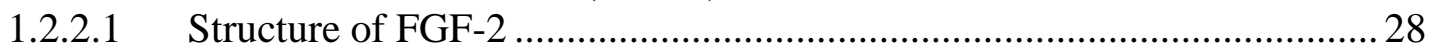

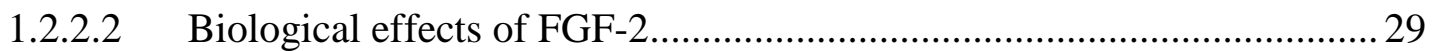

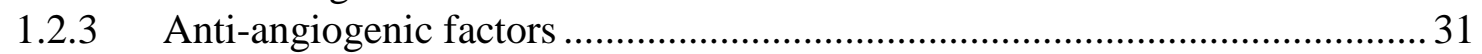

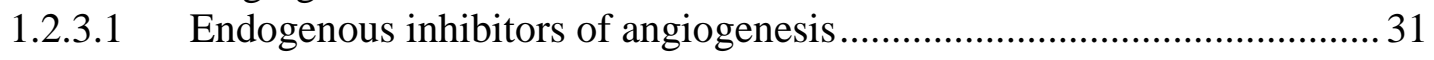

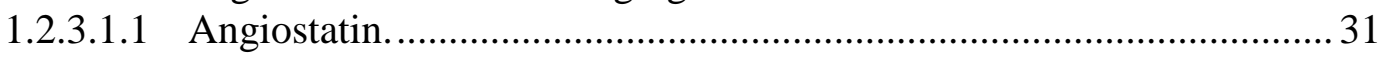

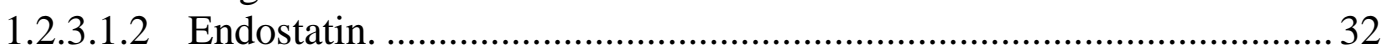

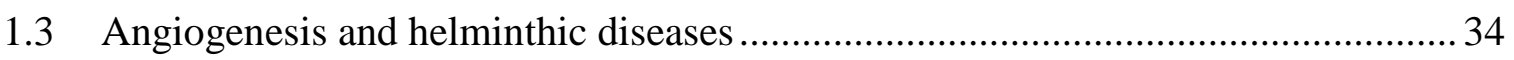

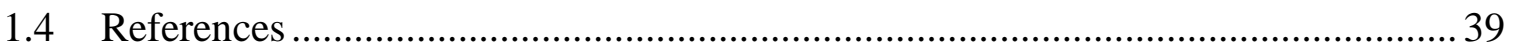

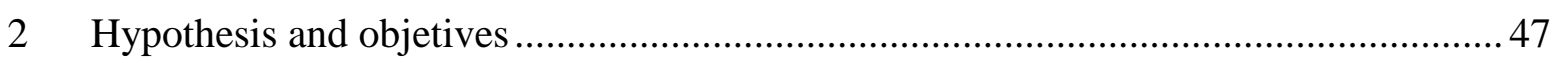

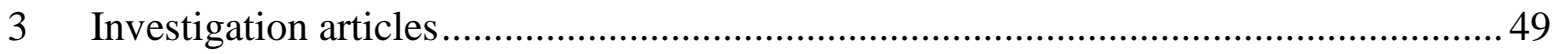

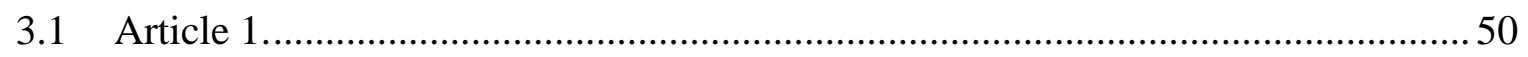

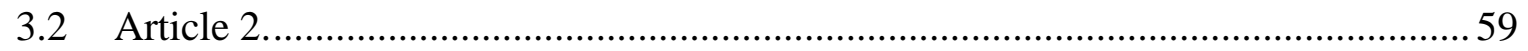

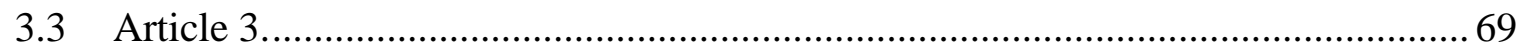

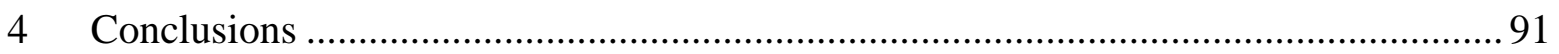

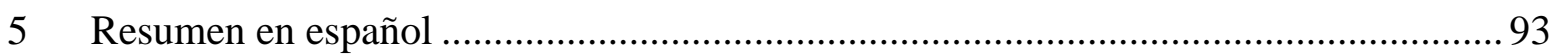

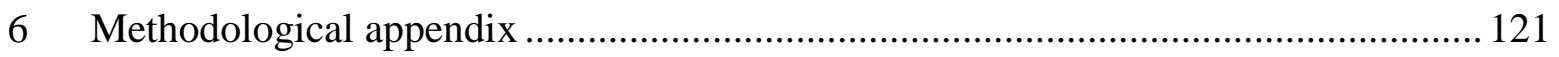

6.1 Collection of rat alveolar macrophages samples for measurement of nitric

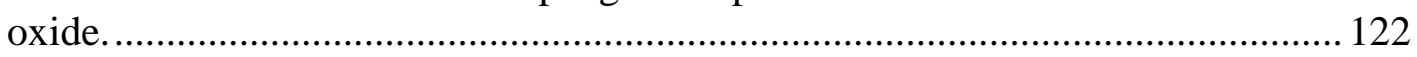

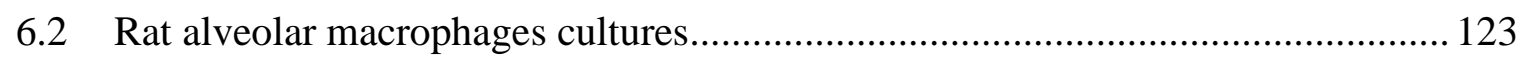

6.3 Determination of viability of rat alveolar macrophages ..................................... 124

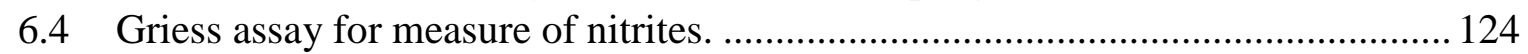

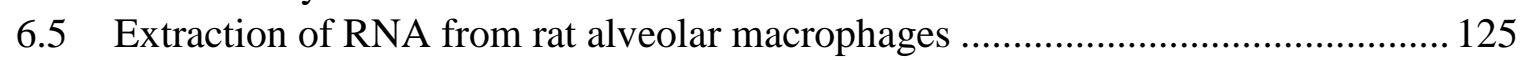

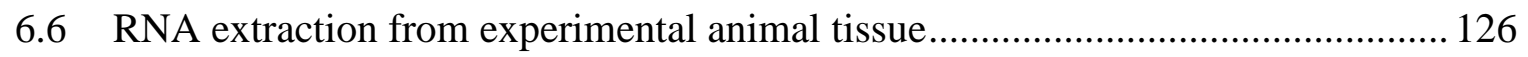

6.7 RT-PCR for detection of VEGF and FGF2 in alveolar macrophages ................... 127

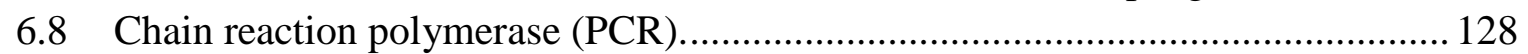

6.9 DNA electrophoresis in agarose gel with ethidium bromide ................................ 129

6.10 Life cycle of Schistosoma mansoni in laboratory …............................................. 130

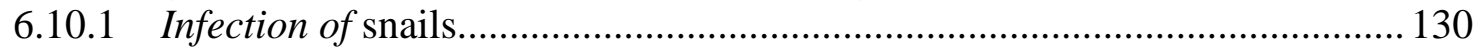

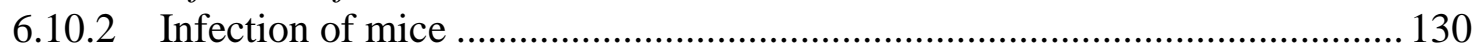

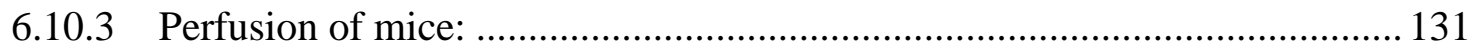


6.11 Adult worm antigens from S. mansoni (AWASm).

6.12 Cercarial antigen of Schistosoma mansoni (CSm)

6.13 Life cycle of Strongyloides venezuelensis in laboratory

6.14 Decontamination of larvae and female adult of S. venezuelensis ............................ 136

6.15 Necropsy of mice infected with Strongyloides venezuelensis.

6.16 Obtanining different antigens from third stage of larvae (L3) and female parthenogenetic from $S$. venezuelensis.

6.16.1 Soluble antigen preparation from $S$. venezuelensis L3 (L3-PBS).

6.16.2 Alkaline extraction of adult female antigen of S. venezuelensis (FALK)

6.16.3 Preparation of the excretory/secretory of L3 (L3-ES) antigen form S. venezuelensis

6.16.4 Female excretory/secretory antigens preparation of S. venezuelensis. 140

6.17 Mc Master egg counting for quantitation of nematode eggs 140

6.18 Enzyme-linked immunosorbent assay (ELISA). 


\section{Abbreviations}

Ang1

ANOVA

bp

BSA

cDNA

DMEM

DMSO

dNTP

EDTA

eg.

ELISA

F-ALK

F-ES

FGF-2

GAPDH

HIF-1

HSPG

iNOS

i.p

Ig

IL

L3

L3-ES

L3-PBS

L-NAME

LPS

lsrRNA

mRNA

mtRNA

MTT

NO

nRNA

OD
Angiopoietin 1

Analysis of variance

Base pairs

Bovine serum albumin

Complementary deoxyribonucleic acid.

Dulbecco's modified Eagle Medium.

Dimethyl sulfoxide

Deoxyribonucleotide triphosphate

Ethylenediaminetetra-acetic acid

Exemple

Enzyme-linked immunosorbent assay

Alkaline extract of adult $S$. venezuelensis

Female excretory/secretory antigens of $S$. venezuelensis

Fibroblast growth factor- 2

Glyceraldehyde 3-phosphate dehydrogenase

Hypoxia-inducible factor 1

Heparin sulfate proteoglycans

Inducible nitric oxide synthase

Intraperitoneal

Immunoglobulin

Interleukin

Larval stage of nematodes

Excretory/secretory antigens of larvae the $S$. venezuelensis

PBS-soluble extract antigen of larvae the $S$. venezuelensis

$\mathrm{N}^{\mathrm{w}}$-Nitro-L-arginine methyl ester

Lipopolysaccharide

Large subunit RNA

Messenger RNA

Mitochondrial RNA

3-[4,5-dimethyl-thiazol-2-yl]-2,5-diphenyl tetrazolium bromide Nitric Oxide

Nuclear RNA

Optical density 
PDGF

p.i.

PIGF

PMSF

SDS-PAGE

PBS

PCR

RNA

rRNA

RT-PCR

$\Sigma$

s.c.

SD

SEM

$\mathrm{sp} / \mathrm{spp}$

ssrRNA

TNF

tRNA

uv

VEGF
Platelet-derived growth factor

Post-infection

Placental growth factor

Phenilmethysulfonylfonylfluoride

Sodium dodecyl sulphate-polyacrylamide gel electrophoresis

Phosphate buffered saline

Polymerase chain reaction

Ribonucleic acid

Ribosomal RNA

Reverse transcriptase polymerase chain reaction

Sum (statistic)

Subcutaneous

Standard deviation

Standard error of the mean

Specie/species

Small subunit RNA

Tumour necrosis factor

Transfer RNA

Ultraviolet

Vascular Endothelial Growth Factor 


\section{Introduction}


Knowledge on angiogenesis control has been a major advance in the understanding of the pathogenesis of many diseases in the last decades. The studies about the role of angiogenic and antiangiogenic factors in the biology of neoplastic (tumor growth and development of metastases) are most abundant in the literature. However, both the generation and inhibition of new vessel formation plays an important role in other pathophysiological processes (eg. ischemia, infection and inflammation).

Firstly, we have divided the introduction in three sections: we briefly point out the basic concepts of angiogenesis and vasculogenesis, as well as their role in neoplastic and non-neoplastic diseases.

In a second section we study the characteristics of the two major angiogenic factors: vascular endothelial growth factor (VEGF) and fibroblast growth factor-2 (FGF-2). Specifically, the structural features of the above factors and the biological mechanism of action will be indicated. Also, antiangiogenic factors as endostatin, a potent inhibitor of endothelial cell proliferation, migration, angiogenesis and tumor growth will be studied.

Finally, we discuss the role of angiogenic and antiangiogenic factors in the pathogenesis of helminthic diseases. Until now, only very little information has been found and virtually confined to infection with Schistosoma spp, filarial species, Taenia solium and Trichinella spp.

\subsection{Angiogenesis}

Vertebrates, including mammalian species, have a closed circulation system for supplying nutrient and oxygen to the tissues in the body. The large and small blood vessels in this circulation system consist of two major cell types, one is the vascular endothelial cells lining the inside of the vessels (monolayer), and the other is the smooth muscle cells which regulate the contraction and dilation of blood vessels. The blood vessels are developed by several steps in embryogenesis, vasculogenesis (blood vessel formation from precursor cells), angiogenesis (blood vessel formation from pre-existing vessels and vascular endothelial cells), and vascular remodelling. 
Angiogenesis, the process of new blood vessel formation from pre-existing ones, plays an important role in various physiological and pathological conditions, including embryonic development, wound repair, inflammation, and tumor growth (Carmeliet and Jain, 2000). Uncontrolled release of angiogenic growth factors and alteration of the production of natural angiogenic inhibitors, with a consequent modification of the angiogenic balance, are responsible for the uncontrolled endothelial cell proliferation that takes place during tumor neovascularization and in angiogenesis dependent diseases (Folkman, 2000).

Animal cells need oxygen and nutrients for their life and are there located within 100-200 $\mu \mathrm{m}$ of blood vessels with a limit for oxygen (Figure 1.1). For each organism that growth beyond this size, they must recruit new blood vessels by vasculogenesis and angiogenesis. Undoubtly blood vessels are essential for growing tumors; metastasize to another organ and also for treatment and deliver drugs to all regions of a tumor in effective quantities (Carmeliet, 2000).

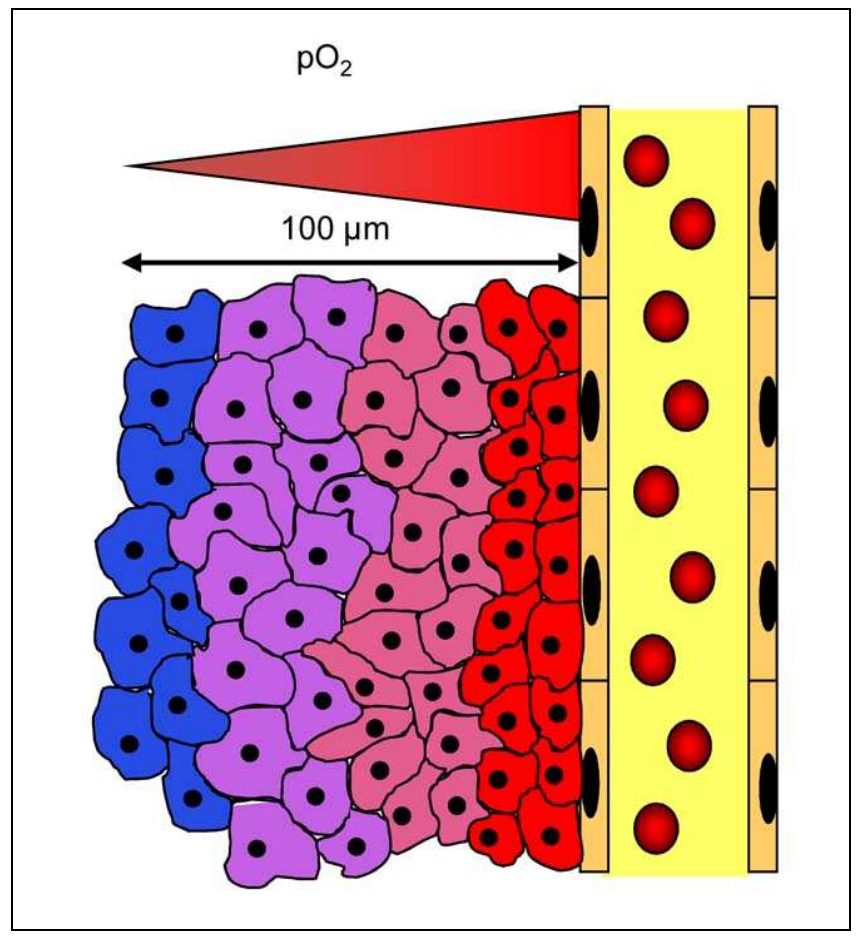

Figure 1.1: Oxygen gradient concentration in tissues 


\subsubsection{Angiogenesis in tumors}

In 1971, Folkmann proposed that tumor growth and metastases depend on angiogenesis, and therefore blocking angiogenesis could be a strategy to stop tumor growth.

In the initial stages of malignant tumors there is a balance between the proliferation of neoplastic cells and their destruction, by both apoptosis and immune control. When the primary tumor reaches a size limit, the local concentration of oxygen decrease and then cells produce angiogenic factors. Moreover, tissue destruction leads to the next release of antiangiogenic substances. Given that the average life of anti-angiogenic factors is greater than the stimulant, initially tumor growth and metastasis development is controlled. However, when the balance is altered in favor of proangiogenic activity, takes place the formation of new vessels with the consequences noted in following sections.

Pro-angiogenic factors includes several molecules released by parenchymal or inflammatory cells in response to mechanical factors, metabolic (eg. hypoxia, acidosis) or immune response. Moreover, tissue destruction leads to generation of molecules with antiangiogenic potential. Table $1.1 \mathrm{a}$ and $1.1 \mathrm{~b}$ include the main substances identified, based on the literature (O'Reilly et al. 1997, Sathornsumetee and Rich, 2007). The predominance of angiogenic factors leads to the formation of new blood vessels from endothelial precursors both local and mobilized from the bone marrow.

Tumor angiogenesis involves both blood vessels and the lymphatics vessels. Regarding to blood vessels can be observed differences in comparison with the normal vasculature. Thus, from a macroscopic point of view, the distribution is very disorganized with dilated tortuous vessels, an irregular diameter and excessive branching and shunts. Microscopically, the endothelium has numerous openings (fenestrate endothelial, vesicles, transcellular holes), are widened intercellular junctions and basement membrane is discontinuous or absent. The smooth muscle surrounding the endothelial cells does not contract in response to normal stimuli, which limits the use of vasoconstrictors in antitumor treatment. The main alterations of lymphatics vessels were compression of the localized within the tumor and dilation of those located in the periphery (by excess VEGF-C, see below). These enlarged lymph vessels can pick neoplastic cells derived from the surface of the tumor and thereby facilitate lymphatic metastasis. 
Table 1.1a: Pro-angiogenic factor receptors their abbreviations and functions.

\begin{tabular}{|c|c|c|}
\hline Factor/Receptor & Abbreviations & Functions \\
\hline $\begin{array}{l}\text { Vascular endotelial growth } \\
\text { factors }\end{array}$ & VEGFs & $\begin{array}{l}\text { Stimulates vasculogenesis } \\
\text { Stimulates angiogenesis } \\
\text { Increases vascular permeability } \\
\text { Promotes leucocyte adhesion }\end{array}$ \\
\hline $\begin{array}{l}\text { Vascular endotelial growth } \\
\text { factor receptors }\end{array}$ & VEGFRs & \multirow[t]{2}{*}{$\begin{array}{l}\text { Integrate angiogenic and survival } \\
\text { signal }\end{array}$} \\
\hline Neuropilin-1 & NRP-1 & \\
\hline Angiopoietin-1 & Ang-1 & \multirow{2}{*}{$\begin{array}{l}\text { Stabilize vessels } \\
\text { Inhibit permeability }\end{array}$} \\
\hline Angiopoietins receptor & Tie-2 & \\
\hline $\begin{array}{l}\text { Platelet derived growth factor- } \\
\text { BB }\end{array}$ & PDGF-BB & Recruit smooth muscle cells \\
\hline Transforming growth factor $\beta 1$ & TGF- $\beta 1$ & \multirow{2}{*}{$\begin{array}{l}\text { Stimulate extracellular matrix } \\
\text { production }\end{array}$} \\
\hline Endoglin & & \\
\hline Fibroblast growth factor-2 & FGF-2 & Stimulates angiogenesis \\
\hline Integrins $\alpha v \beta 3, \alpha v \beta 5, \alpha 5 \beta 1$ & & $\begin{array}{l}\text { Receptors for matrix } \\
\text { macromolecules and proteinases }\end{array}$ \\
\hline VE-Cadherine & CD31 & Endothelial junctional molecule \\
\hline Ephrins & & $\begin{array}{l}\text { Regulate arterial/venous } \\
\text { determination }\end{array}$ \\
\hline Matrix metalloproteinases & MMPs & $\begin{array}{l}\text { Remodel matrix, release and } \\
\text { activate growth factors }\end{array}$ \\
\hline Nitric oxide synthases & NOSs & \multirow{2}{*}{$\begin{array}{l}\text { Vasodilate } \\
\text { Stimulate angiogenesis }\end{array}$} \\
\hline Cyclooxygenase-2 & $\mathrm{COX}-2$ & \\
\hline Antigen 133 & CD133 & $\begin{array}{l}\text { Angioblast (circulant endothelial } \\
\text { precursor) differentiation }\end{array}$ \\
\hline Inhibitors of differentiation $1 / 3$ & Id1/Id3 & Determine endothelial plasticity \\
\hline
\end{tabular}


Table 1.1b: Anti-angiogenic factor receptors their abbreviations and functions.

\begin{tabular}{|c|c|c|}
\hline Factor / receptor & Abbreviations & Functions \\
\hline $\begin{array}{l}\text { Soluble vascular } \\
\text { endothelial growth } \\
\text { factor } 1\end{array}$ & Soluble VEGFR-1 & Sink for VEGF, VEGF-B \\
\hline Angiopoietin 2 & Ang-2 & Natural antagonist of angiopoietin 1 \\
\hline Thrombospondin $1 / 2$ & TSP-1 /TSP2 & $\begin{array}{l}\text { Inhibits endothelial migration, growth, } \\
\text { adhesion and survival }\end{array}$ \\
\hline Angiostatin & & Suppress tumor angiogenesis \\
\hline $\begin{array}{l}\text { Endostatin (collagen } \\
\text { XVIII fragment) }\end{array}$ & & $\begin{array}{l}\text { Broad spectrum angiogenesis } \\
\text { inhibitor }\end{array}$ \\
\hline $\begin{array}{l}\text { Vasostatin } \\
\text { (Calreticulin fragment) }\end{array}$ & & Inhibits endothelial proliferation \\
\hline Platelet factor 4 & PF-4 & Inhibits binding of VEGF and FGF-2 \\
\hline $\begin{array}{l}\text { Tissue inhibitors of } \\
\text { metalloproteinases }\end{array}$ & TIMPs & \multirow{2}{*}{ Suppress pathological angiogenesis } \\
\hline \multirow[t]{2}{*}{$\begin{array}{l}\text { Proteolytic fragment of } \\
\text { metalloproteinase II }\end{array}$} & PEX & \\
\hline & Meth-1/Meth-2 & $\begin{array}{l}\text { Angiogenesis inhibitors that contain } \\
\text { metalloprotease, thrombospondin and } \\
\text { disintegrin domains }\end{array}$ \\
\hline Cytocines & $\begin{array}{l}\text { IFN- } \alpha,-\beta,-\gamma ; \text { IP-10, } \\
\text { IL-4, IL-12, IL-18 }\end{array}$ & $\begin{array}{l}\text { Inhibits endothelial migration; } \\
\text { Downregulate FGF-2 }\end{array}$ \\
\hline Prothrombin & & Suppress endothelial growth \\
\hline Prolactin & & Inhibits VEGF and FGF-2 \\
\hline $\begin{array}{l}\text { Vascular endothelial } \\
\text { growth factor inhibitor }\end{array}$ & VEGFI & $\begin{array}{l}\text { Inhibitor of endothelial growth and } \\
\text { angiogenesis }\end{array}$ \\
\hline $\begin{array}{l}\text { Secreted protein, } \\
\text { acidic, cysteine-rich }\end{array}$ & SPARC & $\begin{array}{l}\text { Inhibit endothelial binding and } \\
\text { activity of VEGF }\end{array}$ \\
\hline Osteopontin & & Interference with interin signaling \\
\hline
\end{tabular}


The vascular changes described in the previous section determine chaotic intratumoral blood flow with appearance of areas of hypoxia and acidosis, which can select cells that have lost their apoptotic response to hypoxia, which is then clonally, expand. Furthermore, the identified angiogenic factors can modulate the expression of cell adhesion molecules and other surface markers on tumor vascular endothelium. For example, VEGF and tumor necrosis factor- $\alpha$ (TNF- $\alpha)$ upregulate, while the growth fibroblast growth factor (FGF) and transforming growth factor- $\beta 1$ (TGF- $\beta 1$ ) downregulate adhesion molecules. Both phenomena (chaotic blood supply and nonuniform expression of adhesion molecules) explain the low and irregular interaction between leukocytes and endothelium in tumor vessels.

Finally, we note that the above phenomena depend on both the tumor type and the location in relation to the type of stromal cells present (Gohongi et al., 1999)

\subsubsection{Angiogenesis in non-neoplastic diseases}

Inflammation and hypoxia contribute to angiogenesis in non-neoplastic diseases. In a healthy adult, endothelial cells of blood vessels are in a quiescent state. In the presence of hypoxia or inflammation vascular remodeling occurs with formation of new vessels. One aspect of particular interest is that angiogenesis in non-neoplastic, unlike the neoplastic vessels, lead to the formation of blood vessels with a normal structure and function.

Hypoxia is therefore a very important stimulus of angiogenesis as other biological processes that attempt to restore normal tissue oxygenation (Figure 1.2). The basic mechanism is the activation of a protein called HIF-1 (hypoxia-inducible factor 1). HIF1 is a heterodimeric protein formed by the junction of two subunits (HIF- $1 \alpha$ and HIF$1 \beta)$. While HIF-1 $\beta$ is constitutively expressed in all tissues, HIF- $1 \alpha$ is activated in hypoxic conditions. HIF-1 acts on the promoter region of different genes that have a common response element (HRE, HIF-1 responsive element). The main genes activated by HIF-1 are:

- Genes encoding glucose transporters (GLUT-1) or enzymes of glycolysis. The result is a stimulation of anaerobic glycolysis and therefore an increase in lactate production.

- Erythropoietin gene in kidney. Increased release of erythropoietin stimulates the proliferation and differentiation of erythropoietic precursors. 
- Gen of tyrosine hydroxylase, key enzyme in the synthesis of dopamine in the carotid bodies responsible for the circulatory and ventilatory response to hypoxia

- Genes related to angiogenesis such as VEGF, inducible nitric oxide synthase (iNOS), platelet-derived growth factor (PDGF) and angiopoietin 1 (ang1).

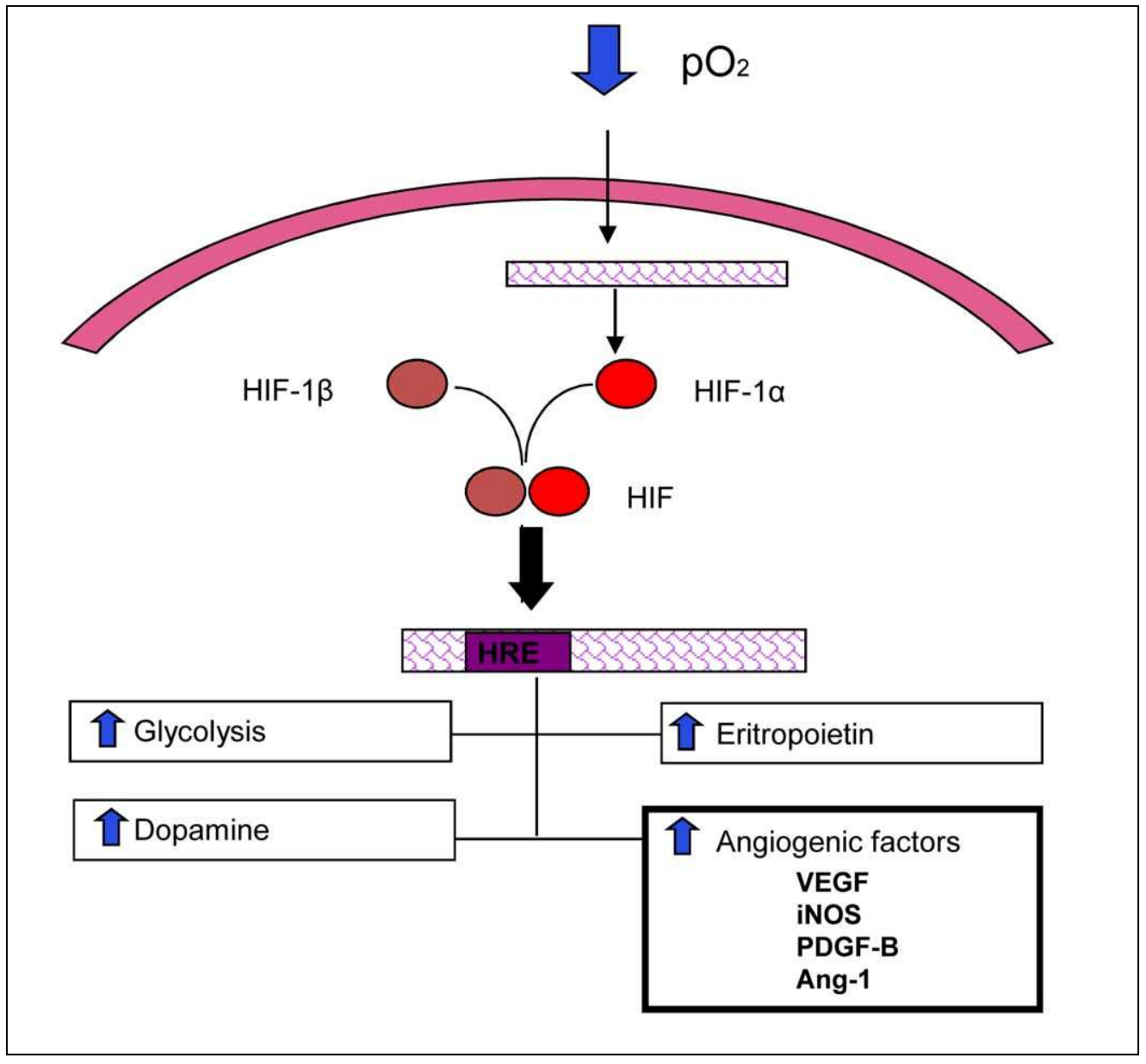

Figure 1.2. Integrative response to hypoxia. 
Furthermore, during inflammation, there is recruitment and activation of blood cells to the focal lesion. Many of these cells (eg. macrophages, platelets, eosinophils, mast cells and other leukocytes) release pro-angiogenic factors summarized in Table Ia. In addition, professional phagocytes are capable of releasing proteases releasing angiogenic factors of the extracellular matrix.

As the previous data, angiogenesis changes such as excess or deficiency have been observed in multiple diseases where hypoxia or inflammation plays an important role. In particular there have been changes in angiogenesis in various types of systemic diseases, both autoimmune diseases (eg. rheumatoid arthritis, lupus erythematosus, systhemic sclerosis) (Carvalho et al., 2007), metabolical diseases (diabetes mellitus) (Crawford et al., 2009) or hematological diseases (Castleman's disease) (Nishi et al., 2000). Moreover, modifications in angiogenesis have seen detected in localized diseases: gastrointestinal tract (eg. Crohn's disease) (Carvalho et al., 2007), eyes (agerelated macular degeneration) (Bressler, 2009), central nervous system (ie. multiple sclerosis, Alzheimer's disease) (Carvalho et al., 2007, Carmeliet et al., 2002) and respiratory diseases (pulmonary emphysema, idiopathic pulmonary fibrosis) (Richter et al., 2005) or kidney diseases (glomerulonephritis) (Foster, 2009).

\subsection{Angiogenic and anti-angiogenic factors.}

\subsubsection{Vascular Endothelial Growth Factor (VEGF).}

The vascular endothelial growth factors (VEGFs) are pleiotropic polypeptides produced by different cell types, including eosinophil (Horiuchi and Weller, 1997). From the early of 1980s that VEGF was identified independently as vascular permeability factor (VPF) and as vascular endothelial cell-specific growth factor in 1980s (Senger et al., 1983; Leung et al., 1989), more studies have been carried out about structure and function of these molecules. In this section, we review briefly the most important aspects of these molecules. 


\subsubsection{Structure of VEGFs}

The VEGFs belong to the VEGF-PDGF (platelet-derived growth factor) super-gene family characterized by 8 cysteine residues are at the same position. 2 out of 8 cysteins generate intermolecular cross-linking, and other 6 cysteins make 3 intramolecular bands to form 3 loop structures (Figure 1.3) (Shibuya, 2001).

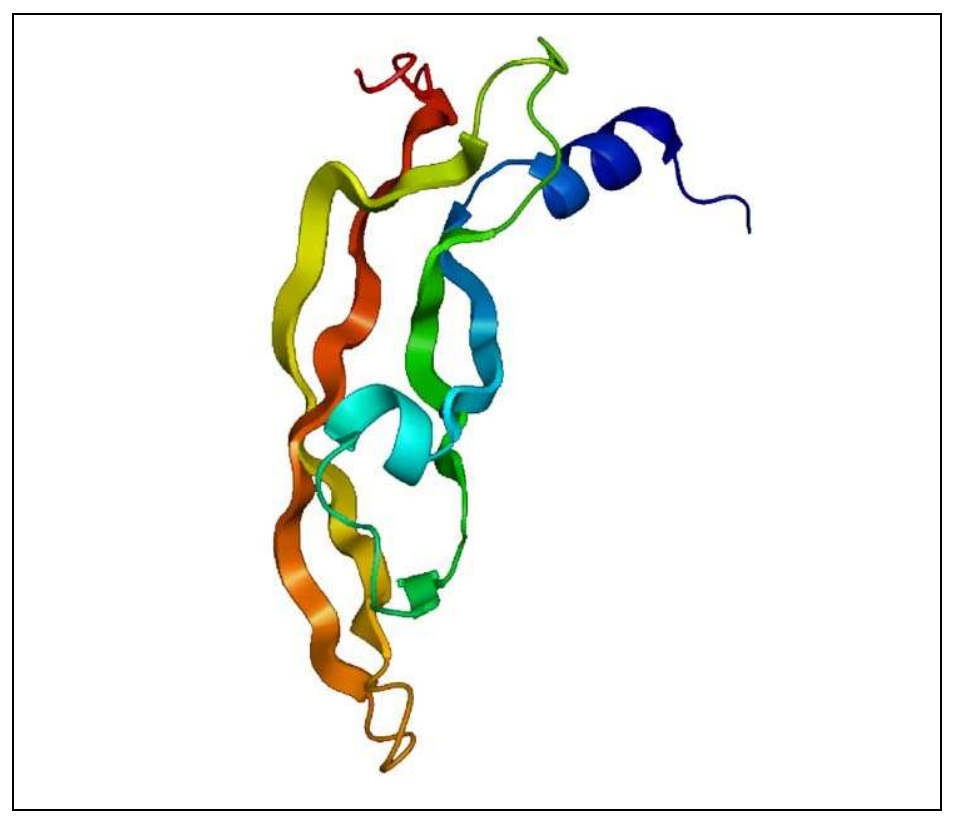

Figure 1.3: Monomer of VEGF-F

Seven molecules of VEGF family have been identified (VEGF-A, VEGF-B, VEGFC, VEGF-D, placental growth factor (PlGF), VEGF-E and VEGF-F). In the mammals, only the first five have biological importance, VEGF-E is a viral protein [Orf-virus (open reading frame, in the genome of Orf virus)-derived VEGF] (Shibuya, 2003) and VEGF-F a protein derived from snake venom (Tokunaga et al., 2005).

Among angiogenic factors identified in humans, vascular endothelial growth factorA (VEGF-A) appears to mediate the basic signalling of angiogenesis (often referred to as simply VEGF). Table 1.2 has shown genetic and functional differences of the five VEGF synthesized in mammals. 
Table 1.2: Types of VEGFs.

\begin{tabular}{llllll}
\hline & VEGF-A & VEGF-B & VEGF-C & VEGF-D & PIGF \\
\hline Chromosome & $6 \mathrm{p} 23.1$ & $11 \mathrm{q} .13$ & $4 \mathrm{q} 34$ & Xp22.31 & $14 \mathrm{q} .24$ \\
\hline Isoforms & YES & YES & NO & NO & YES \\
\hline Receptors & VEGFR1 & VEGFR1 & VEGFR3 & VEGFR3 & VEGFR1 \\
& VEGFR2 & & & NP-1 \\
& NP-1 & NP-2 & & & \\
\hline $\begin{array}{l}\text { Biologic } \\
\text { function }\end{array}$ & Multiple & $\begin{array}{l}\text { A little } \\
\text { known } \\
\text {-Coronary } \\
\text { vessels }\end{array}$ & Lymphangiogenesis & Complementary \\
& & & & of VEGF-A \\
\hline
\end{tabular}

VEGF-A exists as multiple isoforms resulting from alternative pre-mRNA splicing of eight exons (Ladomer et al., 2006). The isoforms are named according to the amino acid number of the monomer, generically termed $\mathrm{VEGF}_{\mathrm{xxx}}$. The general nomenclature of these proteins include, in addition to the general designation (VEGF), the total number of amino acids ( $\mathrm{xxx}$ ) and a suffix (b), if the alternative processing affects the distal portion of exon 8 . The total number of amino acids derived mainly from the inclusion or not of amino acids encoded (totally or partially) by exons 6 and 7 (Figure 1.4).

These structural features have a clear biological significance. Thus, the inclusion or exclusion of exons 6 and 7 modulates interactions with heparan sulfate proteoglycans (HSPGs) and neuropilin receptors. Furthermore, proximal or distal processing of exon 8 has functional consequences, as $\mathrm{VEGF}_{\mathrm{xxx}}$ isoforms are proangiogenic and $\mathrm{VEGF}_{\mathrm{xxx}} \mathrm{b}$ are antiangiogenic.

The major human isoforms of VEGF-A are $\mathrm{VEGF}_{206}, \mathrm{VEGF}_{189}, \mathrm{VEGF}_{189 \mathrm{~b}}, \mathrm{VEGF}_{165}$, $\mathrm{VEGF}_{165 \mathrm{~b}}, \mathrm{VEGF}_{121}$ and $\mathrm{VEGF}_{121 \mathrm{~b}}$. In proangiogenic forms, the isoform that has a major biological importance is $\mathrm{VEGF}_{165}$, followed by $\mathrm{VEGF}_{121}, \mathrm{VEGF}_{189}$ and $\mathrm{VEGF}_{206}$. 


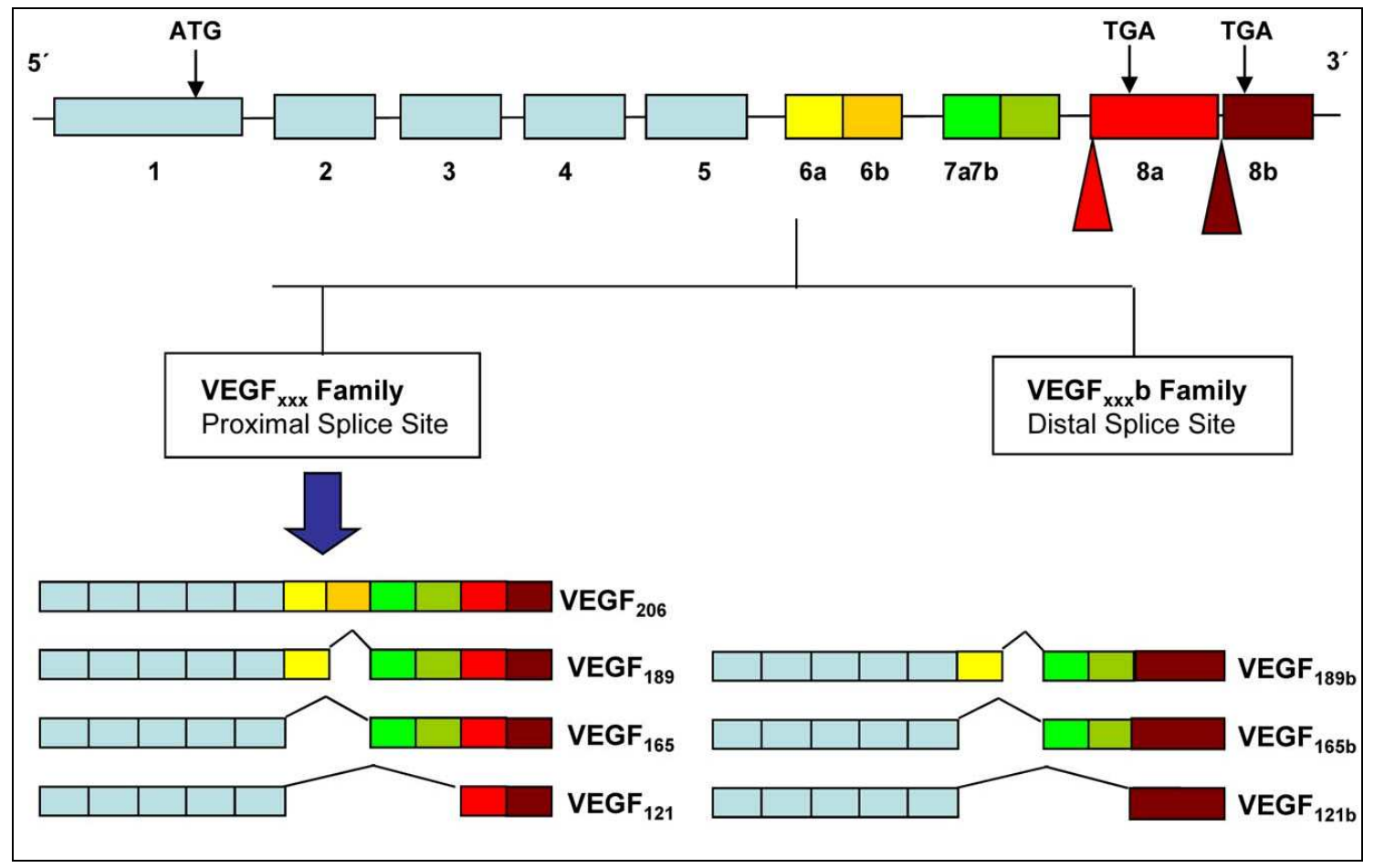

Figure 1.4. Isoforms of VEGF-A.

\subsubsection{Biological effects of VEGF}

VEGF-A exerts its biologic effect through interaction with cell-surface receptors. The receptors for VEGFs are 5 main types (Otrock et al., 2007): VEGF receptor-1 (VEGFR-1; Flt-1), VEGF receptor-2 (VEGFR-2; Kinase insert domain-containing receptor/Flk-1), VEGF receptor-3 (VEGFR-3; Flt-4), selectively expressed on vascular endothelial cells, and neuropilin receptors (NP-1 and NP-2), expressed on vascular endothelium and neurons (Figure 1.5). VEGF-A is capable of binding to all of them except for VEGFR-3. 


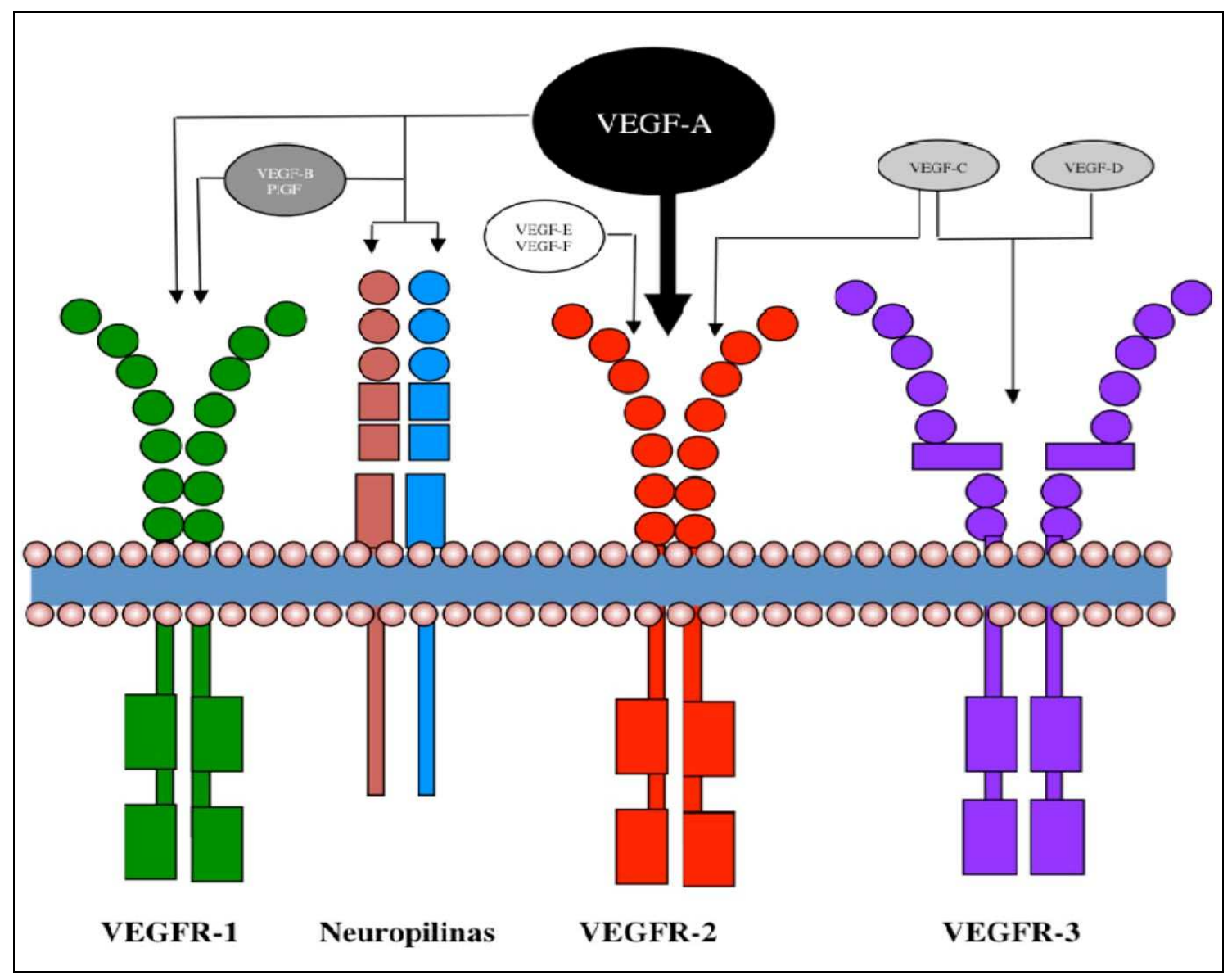

Figure 1.5. VEGFs receptors.

VEGFR-1, also called fms-like tyrosine kinase, Flt-, is a molecule constituted by 7 extracellular Ig-type domains, a transmembrane region and an intracellular tyrosine kinase domain. This molecule is expressed on endothelial cells, osteoblasts, mononuclear phagocytic system cells, placental trophoblast cells, mesangial cells and some hematopoietic stem cells (Zachary and Gliki, 2001). Although the affinity of VEGFR-1 by VEGF-A is 100 times greater than the rates for VEGFR-2, the tyrosine kinase activity of VEGFR-1 is lower. In embryogenesis, the expression of VEGFR-1 is linked to a negative effect on angiogenesis (Shibuya, 2001). In subsequent periods, the binding VEGF-A to VEGFR-1 appears to play an important role in the generation of paracrine signaling in endothelial cells.

VEGFR-2 (also called KDR: kinase-insert domain receptor or flk-1: fms-like kinase) has a structure very similar to VEGFR-1. This receptor is mainly expressed in 
endothelial cells, but it has also been demonstrated in neurons, megakaryocytes, osteoblasts and hematopoietic cells. The main action of VEGF-A is exerted by interaction with this receptor.

The neuropilin 1 and 2 were identified as recipients of a family of molecules known as semaphorins/collapsin, a family of molecules regulating the development of the nervous system. Both are expressed during embryonic development in nervous tissue, cardiovascular, skeletal, while in adults its expression is very wide (Bielenberg, et al., 2006). The role of neuropilin, mainly of NP-1 is to act as a co-receptor for VEGFR-2 by increasing its biological action.

Multiple cell types are capable of trigger synthesis and release of VEGF-A in response to very different stimuli such as metabolic changes (hypoxia, hypoglycemia), hormonal (estrogens), cytokines and other growth factors, proinflammatory molecules and genetic disorders (Shibuya, 2003, Neufeld et al., 1999). One of the best characterized is hypoxia, which induces the stabilization and translocation to the nucleus of two HIF subunits. The union of HIF- $1 \alpha$ and HIF $\beta$ interacting with a specific region of the VEGF gene (HRE, hypoxia response element) induces the synthesis of this molecule (Liao and Johanson, 2007). On the other hand, hypoglycemia, both in laboratory studies (Neufeld et al., 1999) and clinical settings (Dantz et al., 2002) leads to an increased synthesis of VEGF. Estrogens also play an important role in inducing VEGF production in both physiological situations (menstrual cycle, ovulation) and pathological (breast cancer) (Hyder and Stancel, 1999). Multiple cytokines and growth factors (Table 1.3) induce the production of VEGF (Neufeld et al., 1999). 
Table 1.3. Cytokines that stimulates the production of VEGF.

\begin{tabular}{ll}
\hline Cytokine & Abbreviations \\
\hline Fibroblast growth factor 4 & FGF-4 \\
Granulocyte-macrophage colony stimulating factor & GM-CSF \\
Insulin-like growth factor-1 & IGF-I \\
Interleukin 1 & IL-1 \\
Interleukin 5 & IL-5 \\
Keratinocyte growth factor & KGF \\
Transforming growth factor 3 & TGF-3 \\
\hline
\end{tabular}

Among the inflammatory mediators associated with the production of VEGF are oxygen free radicals (Brauchle et al., 1996) and nitric oxide (Chin et al., 1997). Finally, several kinds of genetic alterations present in tumour hereditary diseases or associated with overproduction of VEGF. The best characterized are associated with p53 mutations, the gene encoding the protein of von Hippel-Lindau and PTEN (phosphatase and tension homologue deleted on chromosome 10).

The interaction of VEGF-A and VEGFR-2 receptor triggers a series of initial signaling mechanisms that can be summarized into 5 phases (Schlessinger, 2000): $(i)$ ligand binding to the receptor, (ii) receptor of dimerization; (iii) activation of tyrosine kinases, (iv) receptor of autophosphorylation and $(v)$ binding and activation of adapters to autophosphorylation sites. The signalling pathway of VEGF/VEGFR-2 is different from other growth factors and is summarized in Figure 1.6.

Basically after the interaction between VEGF-A and VRGFR-2, four transduction pathways are activated: (i) Activation of PI3K (represented in purple/violet colours) that converts PIP2 into PIP3. This molecule acts in two ways on the effects of VEGF, first by inhibition of apoptosis (on BAD and caspase 9) and second by stimulating the nitric oxide production by endothelial isoenzyme action on the ONS. (ii) CDC42 activation displayed in share of green which eventually leads to a reorganization of the actin filaments, (iii) Diminished adhesion of endothelial cells (indicated in brown/orange) using as adapter molecule Src and (iv) activation of phospholipase C gamma (via represented in blue) starting from PIP2 generates DAG and IP3. The consequences of this approach are twofold: the generation of prostaglandins and activation of endothelial cell proliferation. 
In summary, the four mechanisms by which VEGF leads to angiogenesis are: (i) increased cell survival, (ii) increase cell migration, (iii) stimulate of cell proliferation and (iv) increase of permeability.

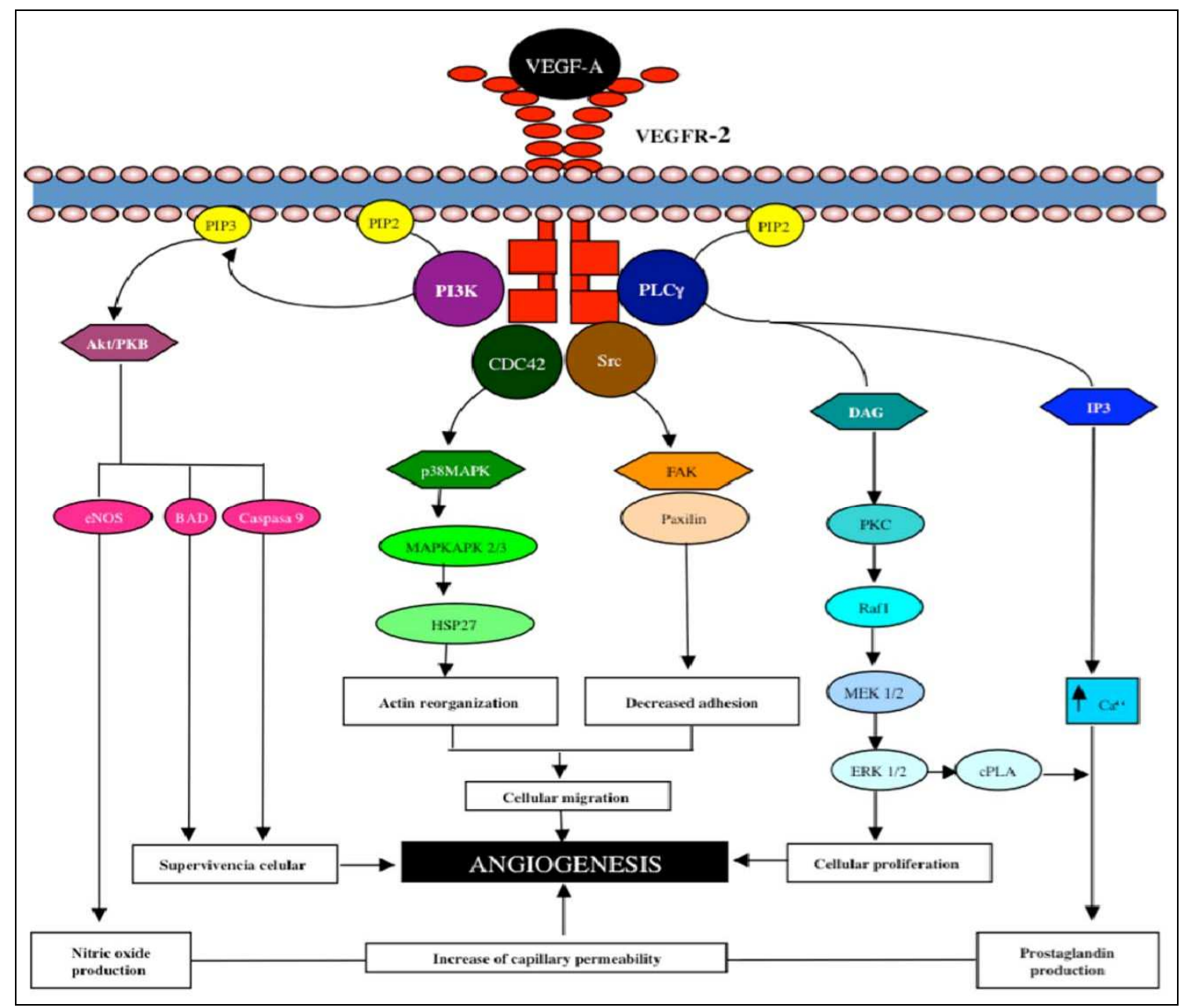

Figure 1.6. Signalling through VEGFR-2.

\subsubsection{Fibroblast Growth Factor-2 (FGF-2)}

FGF-2 or basic FGF (fibroblast growth factor) represents the best-characterized member of the larger family of heparin-binding growth factors. FGF-2 is a potent angiogenic molecule in vivo and in vitro stimulates smooth muscle cell growth, wound healing and tissue repair (Nugent and Iozzo, 2000). In addition, FGF-2 may stimulate hematopoiesis and may play an important role in the differentiation and/or function of the nervous system, the eye and the skeleton. 


\subsubsection{Structure of FGF-2}

FGF-2 was firstly identified as a 146-amino acid that was later found a represent to proteolytic product of the primary $18 \mathrm{kDa}$ heparin binding protein. Larger forms of FGF-2 have been identified with 22, 22.5, 24 and $34 \mathrm{kDa}$, resulting from alternate CUG-translation start sited. FGF-2 contains four cystein residues with no intramolecular disulfide bands, a large number of basic residues with an isoelectric point of 9.6 and two sites that can be phosphorylated by protein kinases A and C, respectively (Bikfalvi et al., 1997).

The interaction of FGF-2 with heparin protects this growth factor against heat or acid denaturation and protease cleavage. While heparin is only synthesized by connective tissue mast cells, heparin sulfate is widely distributed throughout all mammalian tissue and organs attached to core proteins as heparin sulfate proteoglycans (HSPG). HSPGs are a functionally diverse class of molecules found on cell surfaces and in the extracellular matrix where they have been shown to interact with FGF-2 and modulate its distribution and function. The specific sites on FGF-2 involved in binding to heparin and heparan sulfate were revealed from analysis of the crystal structure of FGF-2 (Figure 7).

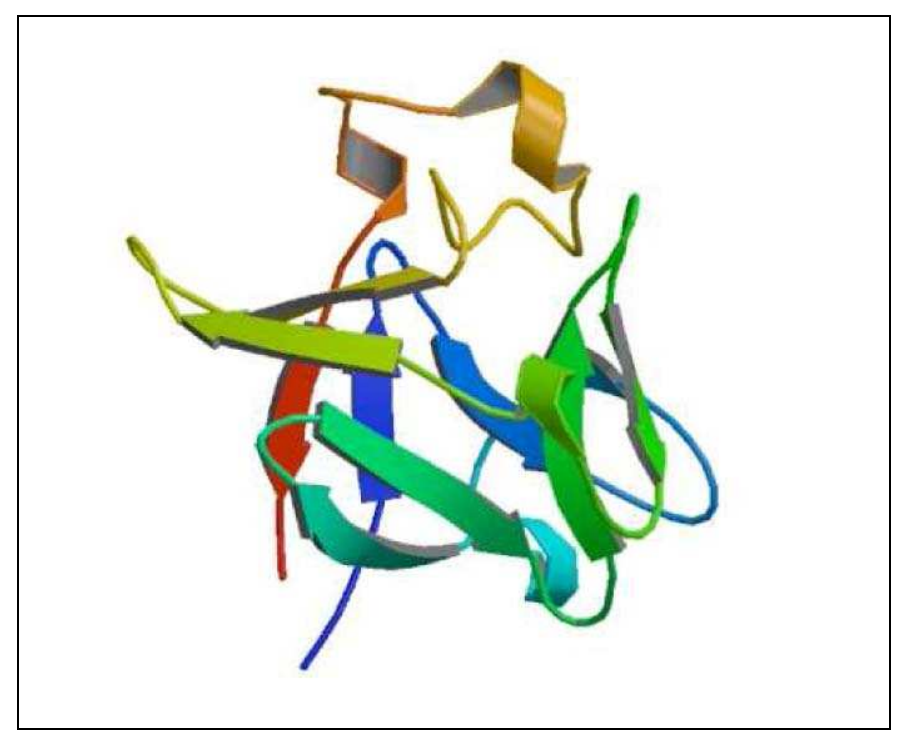

Figure 1.7: X-ray crystal structure of FGF-2 


\subsubsection{Biological effects of FGF-2}

FGF-2 plays key roles in development, remodelling and disease states in almost every organ system (Table 1.4).

Table1.4: Functions of FGF-2.

\begin{tabular}{ll}
\hline Organ & Putative functions \\
\hline Blood vessel & Angiogenesis \\
& Smooth muscle cell proliferation \\
& Blood pressure control \\
& Atherogenesis \\
& Neuronal differentiation and survival \\
Central nervous system & Branching morphogenesis \\
Lung & Fibrosis \\
& Limb development \\
Limb & Myogenesis \\
Muscle & Stimulation of osteoblasts \\
Bone & Spermatogenesis \\
Reproductive system & Photoreceptor survival and transduction \\
Eye & Stimulation of lens epithelial cells \\
& Proliferation of corneal \\
& Melanogenesis \\
Skin & Morphogenesis of the suprabasal keratinocytes \\
\hline
\end{tabular}

One of the best characterized activities of FGF-2 is its ability to regulate the growth and function of vascular cells such as endothelial and smooth muscle cells. FGF-2 has been implicated in the development and growth of new blood vessels (angiogenesis) and in the pathogenesis of vascular disease such as atherosclerosis (Figure 1.8). FGF-2 activity has generally been attributed to the activation of the intrinsic tyrosine kinase activity of its receptors. However, some study has indicated that FGF-2 can stimulate the dephosphylation of the cell surface HSPG syndecan-4, in the absence of its receptor.

FGF-2 has been localized in the nervous system in a variety of species. In human adult brain, strong staining for FGF-2 is observed in central nervous system and in cerebellar Purkinje cells. In the adult brain FGF-2 immunoreactivity is observed in astrocytes, in selected neural populations, and occasionally in microglial cells. In the human adult brain, all FGF-2 isoforms are found (18-, 22-, 24 and 34kDa) (Nugent and 
Iozzo, 2000). Several functions for FGF-2 in the nervous system have been proposed (i.e. regeneration of the oligodendroglial lineage after demyelination or a trophic role in the catecolamin cell groups of the rat brain).

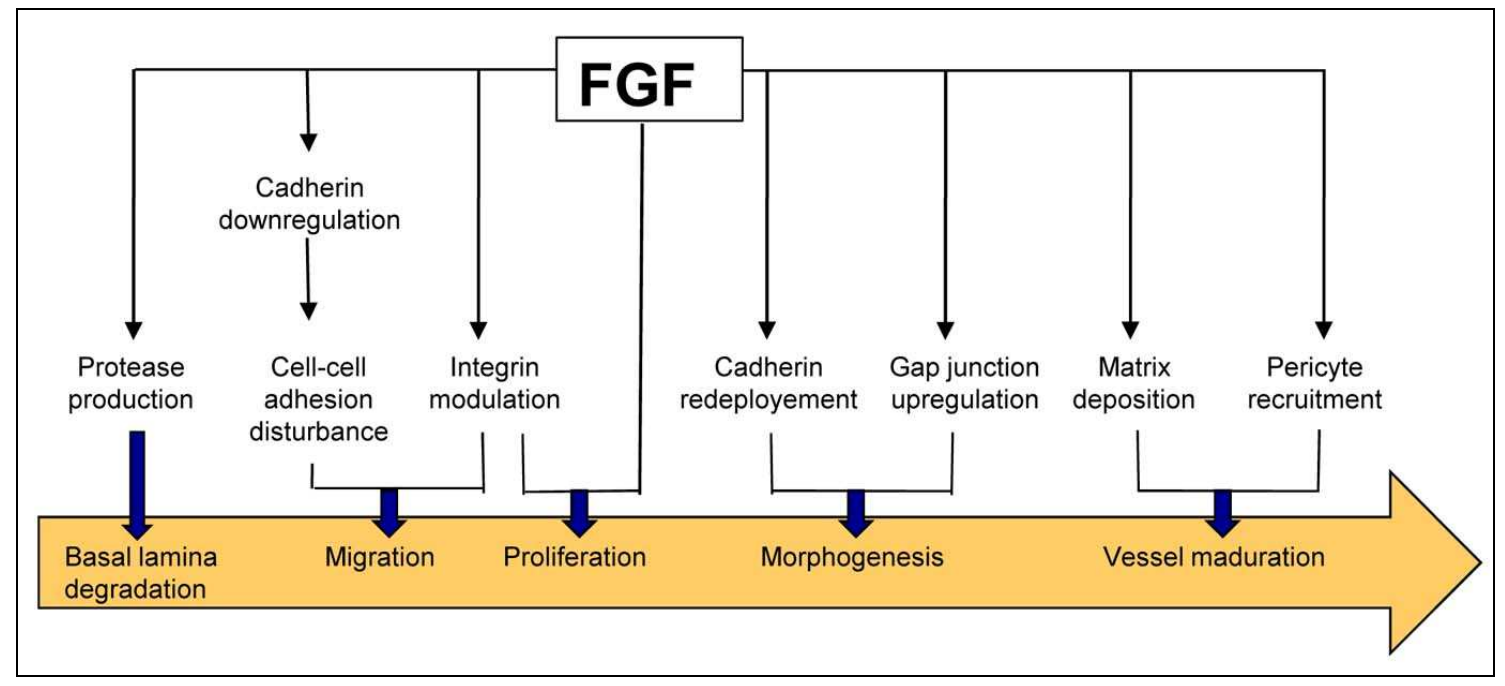

Figure 1.8: Mechanisms of FGF-2 induced angiogenesis.

In the lung, FGF-2 has been related with branching morphogenesis and development of pulmonary fibrosis (Han et al., 1992, Hetzel et al., 2005)

FGF-2, as well as several other FGF family members such as FGF-4 and -8, stimulates limb development. It is, however, unlikely that FGF-2 is the prime candidate for limb formation as its expression pattern does not correlate with the tempor-spatial events occurring during limb generation. FGF-4 and -8 seem to be better candidates for endogenous limb-forming molecules (Olwin et al., 1994).

Development studies indicate that FGF may play an important role in muscle development. Disruption of FGF signaling by expression of a dominant negative FGFR2 result in gastrulation defects that are reflected in the lack of formation of the notochord and muscle (Utton et al., 2001). Even in embryos that show mild defects, muscle formation is impaired.

The proliferation, differentiation and TGF- $\beta$ production of osteoblasts are stimulated by FGF-2 (Devescovi et al., 2008)

FGF-2 modulates basal and LH/human choriogonadotrphin (LN/hCG)-stimulated Leydig cell function (Laslett et al., 1997) 
Several functions have been proposed for ocular FGF-2: $(i)$ induction of retinal regeneration in vitro and protects photoreceptors from light damage, (ii) stimulation of lens epithelial cells to proliferate, migrate, and differentiate into fiber cells, (iii) proliferation of corneal endothelium (Wu et al., 2008).

The proliferation and differentiation of normal human melanocytes and several activities of keratinocytes are dependent on FGF-2 production (Berking et al., 2001).

\subsubsection{Anti-angiogenic factors}

Angiogenesis inhibitors are substances that inhibit the growth of new blood vessels. Angiogenesis inhibitors can be endogenous including proteins or fragments of proteins that are formed in the body (Ribatti, 2009) or exogenous such as drugs or dietary components.

\subsubsection{Endogenous inhibitors of angiogenesis}

The main endogenous inhibitors of angiogenesis are included in Table 1.5.

\subsection{Angiostatin.}

Angiostatin, a $38 \mathrm{kDa}$ specific inhibitor of endothelial cell proliferation, is an internal fragment of plasminogen containing at least three of the kringles of plasminogen (Persano et al., 2007). Angiostatin was isolated from subclone of Lewis lung carcinoma in which the primary tumor inhibited the growth of its metastases. Angiostatin, generated by the primary tumor, was demonstrated to potently inhibit angiogenesis. Really, systemic therapy with angiostatin led to the maintenance of metastases in a microscopic dormant state defined by a balance of apoptosis and proliferation of the tumor cells.

Angiostatin inhibits EC migration and proliferation most likely through its ability to bind a cell surface ATP synthase, which may act as a receptor. Moreover, by inhibiting extracellular matrix (ECM)-stimulated plasminogen activation, it determines a decrease in endothelial cell invasion. Other studies revealed that angiostatin may induce apoptosis in EC, albeit at relatively high concentrations (Benouchan and Colombo 2005). 
Table 1.5. Types o endogenous inhibitors of angiogenesis.

\begin{tabular}{ll}
\hline Origin & Type \\
\hline Matrix derived & Anastellin \\
Arresten & Canstatin \\
Endorepellin & Endostatin \\
& Fibulin \\
& Targeting fibronectin-binding integrins \\
& Thrombospondin-1 and -2 \\
& Tumstatin \\
Non matrix derived & Growth factors and cytokines \\
& Interferons \\
& Interleukins \\
& Pigment epithelium derived factor (PEDF) \\
& Fragments of blood coagulation factors \\
& Angiostatin \\
Antithrombin III \\
Platelet factor-4 \\
Prothrombin kringle 2 \\
2-Methoxyestradiol \\
Chondromodulin \\
Prolactin fragments \\
Soluble Fms-like tyrosine kinase-1 (S-Flt-1) \\
Tissue inhibitors of metalloproteinase (TIMPs) \\
Troponin I \\
Vasostatin \\
\hline Others &
\end{tabular}

\subsection{Endostatin.}

Among the many inhibitors of angiogenesisis endostatin is one of the endogenous inhibitor that has been shown to inhibit the growth of a wide variety of tumors with no apparent toxic side effects. Of particular interest is the lack of acquired drug resistance exhibited by experimental cancers in mice when exposed to repeated doses of endostatin (O’Reilly et al., 1997).

Endostatin is a $20 \mathrm{kDa}$ C-terminal cleavage product of collagen XVIII which belongs to the multiplexin family and is characterized by multiple triple-helix domains and interruptions (Figure 1.9). 


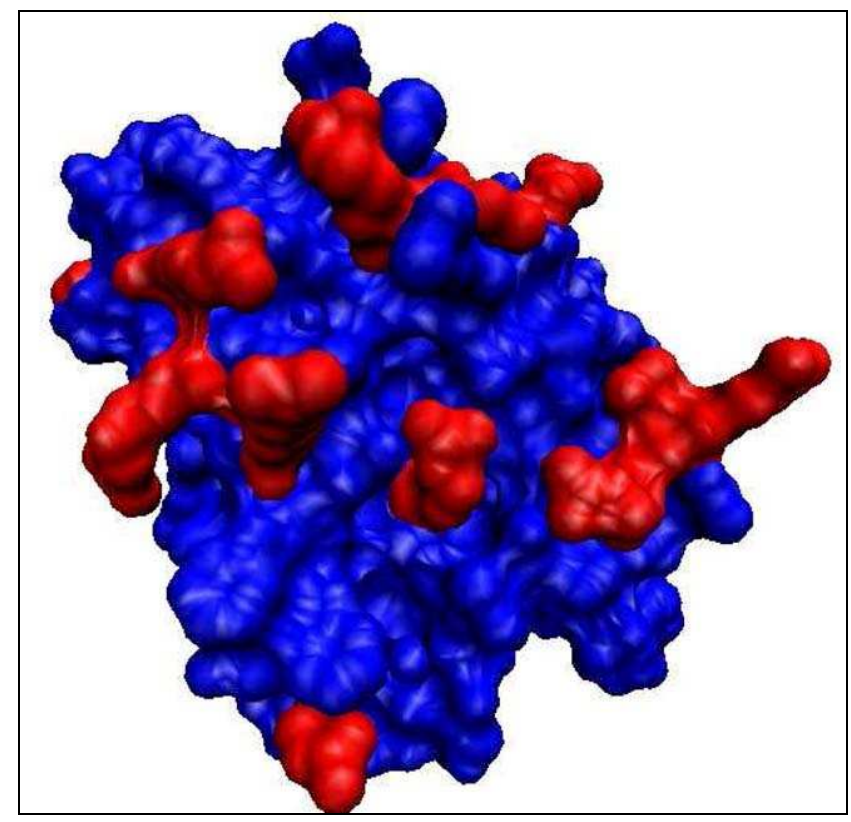

Figure 1.9. X-raycrystal structure of endostatin.

The generation of endostatin from collagen XVIII is catalyzed by proteolytic enzymes such as cathepsin L and matrix metalloproteases (Heljasvaara et al., 2005).

Like many other angiogenesis inhibitors, endostatin has an affinity for heparin. The crystal structure of endostatin reveals an extensive basic patch of 11 instances of arginine, which may serve as a binding site for heparin. This site has recently been shown to be involved in the inhibition of induced angiogenesis (Olsson et al., 2004). At the same time, heparin binding was not observed to play any role in the ability of endostatin to inhibit the migration of endothelial cells. Endostatin binds with low affinity to the heparin sulfate proteoglaycans, glypican-1 and glypican-4, and with high affinity to an unidentified molecule on endothelial cells.

Other experiment has also shown that endostatin associate with proteins such as $\alpha 5$ and $\alpha v$ integrins, fibulin, laminin-1 and tropomyosin. Furthermore, it has been reported that endostatin is internalized by endothelial cells, but not by mouse fibroblasts. Therefore, it is possible that endostatin may present its signaling directly in the cytoplasm without any need for a transducing member receptor.

The physiological functions of endostatin are comparably diverse. Recent studies show that endostatin inhibits renal epithelial cell branching morphogenesis, and may play a role in the regulation of ureteric arborization (Van Hensbergen et al., 2002). 
The ability of endostatin to inhibit tumor growth and angiogenesis in vivo is demonstrated by extensive studies performed on distinct animal models in numerous laboratories throughout the world. Recently, Kalluri's laboratory could provide genetic proof that endostatin is an endogenous angiogenesis inhibitor and a tumor suppressor (Sund et al., 2005). When endostatin was knocked out, tumors grew 2-to 3-fold (200 to $300 \%$ ) faster than wild type mice. In contrast, when endostatin was over-expressed by only 1.6-fold increase of the circulating level to mimic individuals with Down syndrome, tumors grew 3-fold slower than the wild type mice. Finally, some work has convincingly shown that endostatin-deficient mice exhibited increased angiogenesis. Endostatin levels are elevated in certain types of cancer, in intratumoral fluid and malignant ascites and in chronic inflammatory diseases such as rheumatoid arthritis and diabetic retinopathy.

\subsection{Angiogenesis and helminthic diseases}

Although the investigation about angiogenesis and tumor come back nearly 100 yearas ago, but there is existed a little information about the role of angiogenesis and angiogenic factors in helminthiasis, both in humans and in experimental models or laboratory studies.

Angiogenic factors are produced either by the parasite or the host can stimulate neovascularization through a number of different mechanisms (Figure 1.10). As an example, has been demonstrated that nematode parasite $C$. elegans encodes a factor capable binding mammalian VEGF receptors and inducing angiogenesis (Tarsitano et al., 2006). This is named C. elegans pvf-1 gene that codifies a PDGF/VEGF-like factor with a biochemical properties similar to vertebrate PDGF/VEGF growth factors. More important, pvf-1 binds to the human receptors VEGFR-1 (Flt-1) and VEGFR-2 (KDR) and is able to induce angiogenesis. The mechanisms related with host molecules can be divided into three categories; first of all, may be more important, potent angiogenic proteins such as vascular endothelial growth factors (VEGF) and the fibroblast growth factor (FGF-2) induce angiogenesis directly, by stimulation of endothelial cell proliferation, migration and differentiation into vascular tubes. Second, other angiogenic factors, such as interleukin-1, promote angiogenesis indirectly by stimulating inflammatory cells to produce VEGF. And third, angiogenic proteins such as heparinase are proteolytically cleaved, and the released peptides stimulate 
components of the host's immune system, which in turn stimulate the production of other angiogenic factors such as VEGF and FGF-2 (Zcharia et al., 2001). Finally, some angiogenic factors stimulate other mechanisms involved in the final lesions. In fact, experimental data suggest that hypoxia in relation to VEGF may stimulate proliferation of synthesis of collagen type 1 in activated myofibroblast-like rat hepatic stellate cells (Novo et al., 2007). They have shown VEGF and angiopoitin 1 (Ang-1) can operate as hypoxia-dependent, autocrine and paracrine factors able to stimulate nonoriented migration and chemotaxis of human myofibroblas-like rat hepatic stellate cells (HSC/MFs) through the activation of (Ras/Erk) signaling.

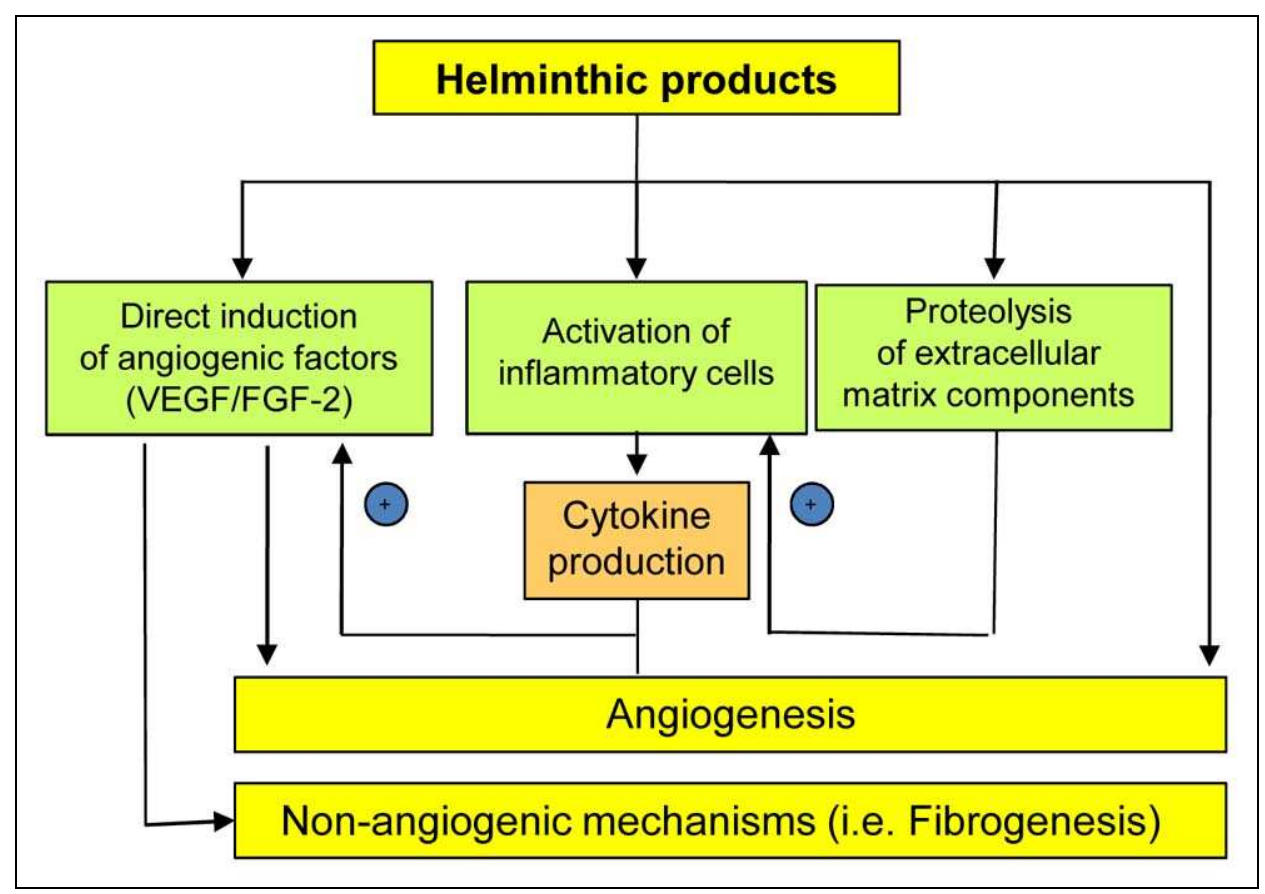

Figure 1.10. Helminths and angiogenesis

In practice, the main information about angiogenesis and angiogenic factors in helminthic diseases is limited to infections caused by Schistosoma spp, filarial, Taenia solium and Trichinella spp.

Schistosomiases are infections caused by different species of the genus Schistosoma. With the exception of cercarial dermatitis and the Katayama syndrome, the pathogenic basis of schistosomiasis is the formation of granulomas around parasite eggs.

Although information is scarce in the literature, we note that in the initial stages of schistosomiasis, there is a stimulation of angiogenesis. Thus, it has been clearly 
demonstrated by histological and immunohistochemical techniques the presence of angiogenesis in several experimental models of schistosomiasis (Farah et al., 2000; Botros et al., 2008; Baptista and Andrade, 2005). In this context is interesting to note several aspects: $(i)$ angiogenesis is an early phenomenon, so in evolutionated phases (such as those has been found in humans) is hard to objectify (Baptista and Andrade, 2005), (ii) an aspect importantly, demonstrated experimentally in the induction of angiogenesis, is the need for repeated exposure to the parasite (Farah et al, 2000) and (iii) genetic factors play an essential role in the angiogenic response to the parasite (Van de Vijver et al, 2006; Rutitzky et al., 2005).

The mechanisms by which Schistosoma spp triggers angiogenesis are of various types and have been obtained in experimental studies. Thus, several studies have identified specific Schistosoma mansoni egg-derived regulatory molecules that include lysophosphatidylserine and prostanoids. Also eggs secrete/excrete additional factors that are capable of stimulating endothelial cell proliferation, migration, p42/44 MAPK phosphorylation and cell sprouting directly. The effect of this factor is not restricted to endothelial cells, but also stimulated vascular smooth muscle cells (Kanse et al., 2005). On the other hand, Schistosoma mansoni soluble egg antigen (SEA) promotes proliferation, increased tube formation, decreased apoptosis and increased 2-fold messenger RNA for vascular endothelial growth factor (VEGF) of human umbilical vein endothelial cells (HUVECs) (Loeffler et al., 2002) These findings suggest that products secreted by schistosome eggs may promote angiogenesis within hepatic granulomas by up-regulating endothelial cell VEGF. Moreover, Schistosome eggs, attached to endothelium (Pearce et al., 2004) indirectly promote angiogenesis through hypoxia and inflammatory response. The main host-derived initiators of this inflammatory response include the early inflammatory cytokine, tumor necrosis factor$\alpha$ (TNF- $\alpha)$ and the endothelial cell-adhesion molecule, intercellular adhesion molecule1 (ICAM). At later stages, is developed periportal fibrosis by a mechanism that primes lymphocytes to produce increased levels of profibrotic molecules that include TGF- $\beta$ and IL-4 (Farah et al., 2000). Finally, extravasation of the egg into the surrounding tissue and disruption of the portal stroma causes the migration of inflammatory cells to the site of egg deposition (Silva et al., 2006). The pre-existing portal stroma, showing normal CD34-immunoreactivity, is disrupted completely in and around the granulomas and is only preserved closely near to the portal vein and bile duct. Modulation of basement membrane components, proteoglycans, collagens and fibronectin imbalance 
the connective stromal tissue matrix, has been described previously in schistosomal granulomas (Jacobs et al., 1998). Proteolysis of the dense extracellular matrix by collagens and matrix metalloprotinases (MMPs), a process preceding angiogenesis, seems necessary to allow the development of larger inflammatory reaction. While the endothelial cell proliferation fraction of a quiescent mature vasculature is $0.01 \%$ (Carmeliet and Jain, 2000), the presence of multiple proliferating cells in each granuloma shows the dynamic angiogenesis in schistosome induced inflammation.

At our knowledge, only two groups have studied the role of angiogenic factors in human schistosomiasis and their results are hardly comparable. Thus, Tawfeek GM et al., (2003) evaluate 90 patients with schistosomiasis related to $S$ mansoni classified in five groups according to sonographic studies: infected lightly, infected heavily, intestinal, early hepatosplenic and periportal fibrosis. When compared with controls, they found that VEGF levels were significantly raised in all schistosomiasis patients groups except lightly infected and intestinal groups. Moreover, the level of VEGF correlated with disease progression from lightly infected to periportal fibrosis patients. Using a different study design, Toledo and colleagues measured serum levels of VEGF in patients with schistosomiasis with or without portal hypertension (de Toledo et al., 2009). These authors found no significant differences between both groups, although the average values in the group with portal hypertension were younger, a fact that coincides with low levels of VEGF detected in patients with cirrhosis from other causes (Shi et al., 2001).

Filariasis is diseases related with the infection of several genus and species of nematodes (Wuchereria bancrofti, Brugia malayi, Brugia timori, Onchocerca volvulus, Loa loa, Mansonella perstans, Mansonella ozzardi and Mansonella streptocerca). Altered angiogenesis has been described in only two types of filarial diseases: lymphatic filariasis (Pfarr et al., 2009) and onchocerciasis.

Clinical lymphatic filariases (and specifically infections related with W. bancrofti) are characterized with lymphoedema, lymph vessel dilation, lymph extravasation and, in some cases, the development of elephantiasis. There is some evidence of the role of angiogenic factors (and specifically of the family of VEGF) in the pathogenesis of lymphatic filariasis. Thus, in a longitudinal study in 63 Polynesian patients living in an hyperendemic focus of $W$. bancrofti, chyluria was associated with increased vascular endothelial growth factor (VEGF) levels, whereas elephantiasis presented a high 
endothelin-1 (ET-1) profile (Esterre et al., 2005). On the other hand, host genetics is related with the clinical evolution of lymphatic filariasis. Specifically, in a cohort of lymphatic filariasis patients from Ghana, three VEGF-A promoter polymorphisms were examined (Debrah et al., 2008). The authors found that C/C genotype at -460 was significantly higher in hydrocele patients and in patients with high serum VEGF levels. Finally, in a cohort of bancroftian filariasis in Ghana, serum VEGF-C and sVEGFR-3 were elevated at basal evaluation (Debrah et al., 2006). Doxycycline-treated patients (for Wolbachia spp eradication) decrease VEGF-C and sVEGFR-3 at a level close to that of endemic normal values, with amelioration of supratesticular dilated lymphatic vessels and with an improvement of lymphatic pathology.

Onchocerciasis is characterized by two types of clinical manifestations: subcutaneous nodules (macrofilarial-related) and skin and ocular lesions (microfilarial-related). $O$. volvulus nodules in perfusion studies have different patterns of angiogenesis (Smith et al., 1988). Small nodules had an extensive blood supply, diffusely distributed throughout the nodule matrix, and in close association with the coils of the worms. In bigger nodules the central area appeared more dense, and intense vascularization appeared to be more peripheral; in the largest nodules the central core was not well vascularized, but a band of heavy vascularization was seen at the margin of the core, fed by superficial vessels and in close contact with worm coils. At least one derived $O$. volvulus protein (Ancylostoma secreted protein homologue) can contribute to abnormal angiogenesis (Higazi et al., 2003)

Neurocysticercosis is a common central nervous system (CNS) infection caused by Taenia solium metacestodes. In this infection is well-documented the importance of the granulomatous response in their pathogenesis. A small series of eight patients with neurocysticercosis subjected to craniotomy for histological and immunohistochemical analysis, shows dying parasite surrounded by a mature granuloma with associated fibrosis, angiogenesis and an inflammatory infiltrate. The most abundant cell types were plasma cells, B and T lymphocytes (Th1), macrophages, and mast cells (Restrepo et al., 2001). Moreover, an increased angiogenesis has been observed in animal models of neurocysticercosis (Sikasunge et al., 2009).

Trichinellosis is a nematode infection in which primarily affects striated muscle cells. Larvae of Trichinella spp initiate the transformation of myocytes into nurse cells that become surrounded by elaborate networks of blood vessels. In mice experimentally 
infected by Trichinella spp several vessel abnormalities were detected (Baruch and Despommier, 1991). Thus, vascular complexes were found only around infected myocytes and were characterized by large circumferential vessels that give rise to the smaller channels of the retes. The secondary vessels vary widely in caliber and are distributed in a random fashion. Three types of network were found: simple, complex, and hypercomplex, and they were distributed normally, with the complex retes the most common. Comparison of the structure of the baskets with that of vessels in surrounding uninfected muscle strongly suggests that the vascular retes are the result of de novo angiogenesis induced during the infection. In this setting, excretory/secretory products of larval T. spiralis and T. pseudospiralis have been related with degenerative/ regenerative muscular changes and angiogenesis (Ko et al., 1994).

\subsection{References}

Baptista AP, Andrade ZA. 2005. Angiogenesis and schistosomal granoloma formation. Mem Inst Oswaldo Cruz 100: 183-185

Baruch AM, Despommier DD. 1991. Blood vessels in Trichinella spiralis infections: a study using vascular casts. J Parasitol 77: 99-103

Benouchan M, Colombo BM. 2005. Anti-angiogenic strategies for cancer therapy Int J Oncol 27: 563-71.

Berking C, Takemoto R, Satyamoorthy K, Elenitsas R, Herlyn M. 2001. Basic Fibroblast Growth Factor and Ultraviolet B Transform Melanocytes in Human Skin. Am J Pathol 158: 943-953

Bikfalvi A, Klein S, Pintucci G, and Rifkin D. 1997. Biological roles of fibroblast growth factor-2. Endocr Rev 18: 26-45.

Botros SS, Hammam OA, El-Lakkany NM, El-Din SH, Ebeid FA. 2008. Schistosoma haematobium (Egyptian strain): rate of development and effect of praziquantel treatment. J Parasitol 94: 386-94

Brauchle M, Funk JO, Kind P, Werner S, 1996. Ultraviolet B and H2O2 are potent inducers of vascular endothelial growth factor expression in cultured keratinocytes. J Biol Chem 271: 21793-7. 
Bressler SB, 2009. Understanding the role of angiogenesis and antiangiogenic agents in age-related macular degeneration.Ophthalmology 116(10 Suppl):S1-7.

Capo VA, Despommier DD, Polvere RI. 1998. Trichinella spiralis: vascular endothelial growth factor is up-regulated within the nurse cell during the early phase of its formation. J Parasitol 84: 209-14.

Carmeliet P, Jain RK. 2000. Angiogenesis in cancer and other diseases. Nature 407: 249-57.

Carmeliet P. 2000. Mechanisms of angiogenesis and arteriogenesis. Nature Med 6, 389395

Carmeliet P, Storkebaum E. 2002. Vascular and neuronal effects of VEGF in the nervous system: implications for neurological disorders. Semin Cell Dev Biol 13:3953.

Carvalho J, Blank M, Shoenfeld Y. 2007. Vascular Endothelial Growth Factor (VEGF) in Autoimmune Diseases. J Clin Immunol 27: 246-256

Chin K, Kurashima Y, Ogura T, Tajiri H, Yoshida S, Esumi H. 1997. Induction of vascular endothelial growth factor by nitric oxide in human glioblastoma and hepatocellular carcinoma cells. Oncogene 15:437-42.

Crawford TN, Alfaro DV, Kerrison JB, Jablon EP. 2009. Diabetic retinopathy and angiogenesis. Curr Diabetes Rev 5: 8-13.

Dantz D, Bewersdorf J, Fruehwald-Schultes B, Kern W, Jelkmann W, Born J, Fehm HL, Peters A. 2002. Vascular endothelial growth factor: a novel endocrine defensive response to hypoglycemia. J Clin Endocrinol Metab 87: 835-40.

Debrah AY, Mand S, Toliat MR, Marfo-Debrekyei Y, Batsa L, Nürnberg P, Lawson B, Adjei O, Hoerauf A, Pfarr K. 2007. Plasma vascular endothelial growth Factor-A (VEGF-A) and VEGF-A gene polymorphism are associated with hydrocele development in lymphatic filariasis. Am J Trop Med Hyg 77: 601-8.

de Toledo CF, Carvente CT, Shigueoka DC, and Borges DR 2009. Endothelial markers in schistosomiasis patients with or without portal hypertension. Dig Dis Sci 54: $1331-1336$.

Devescovi V, Leonardi E, Ciapetti G, Cenni E, 2008. Growth factors in bone repair. Chir Organi Mov 92: 161-8. 
Dhanabal M, Hanai JI, Venkataraman G, Shriver Z, Keiser N, Kalluri R, Zeng H, Mukhopadhyay D, Chen RL, Lander AD, Hagihara K, Yamaguchi Y, Sasisekharan R, Cantley L, Sukhatme VP. 2001 Cell surface glypicans are low affinity endostatin receptors. Mol Cell 7: 811-822

Esterre P, Plichart C, Huin-Blondey MO, and Ngyen LN, 2005. Soluble cellular adhesion molecules, selectins, VEGF and endothelin-1 in patients with Wucheria bancrofti infection and association with clinical status. Parasite Immunol 27: 9-16.

Farah IO, Mola PW, Kariuki TM, Nyindo M, Blanton RE, King CL. 2000. Repeated exposure induces periportal fibrosis in Schistosoma mansoni-infected baboons: role of TGF-beta and IL-4. J Immunol 164:5337-43

Felbor U, Dreier L, Bryant RA, Ploegh HL, Olsen BR, Mothes W 2000. Secreted cathepsin L generates endostatin from collagen, XVIII. EMBO J. 19, 1187-1194.

Folkman J 2006 Antiangiogenesis in cancer therapy-endostatin and its mechanism of action. Exp Cell Res 312:594-607

Folkman J. in Cancer medicine (eds Holland, J.F. et al.,) 132-152(Decker, Ontario, Canada, 2000).

Foster RR. 2009. The importance of cellular VEGF bioactivity in the development of glomerular disease. Nephron Exp Nephrol 113(1):e8-e15.

Gohongi T, Fukumura D, Boucher Y, Yun CO, Soff GA, Compton C, Todoroki T, Jain RK. 1999. Tumor-host interactions in the gallbladder suppress distal angiogenesis and tumor growth: involvement of transforming growth factor beta1. Nature Med 5:1203-8

Guiner C, Plet A, Galiana D, Gesnel MC, Del Gatto-Konczak F, Breathnach R. 2001. Polypyrimidine tract-binding protein represses splicing of a fibroblast growth factor2 gene alternative exon through exon sequences. J Biol Chem 23: 43677-87.

Hall LR, Pearlman E. 1999. Pathogenesis of onchocercal keratitis (river blindness). Clin Microbiol Rev12: 445-53.

Han RN, Liu J, Tanswell AK, Post M, 1992. Expression of basic fibroblast growth factor and receptor: immunolocalization studies in developing rat fetal lung. Pediatr Res 31:435-40.

Hanahan D \& Weinberg R.A, 2000. The hallmarks of cancer. Cell 100: 57-70. 
Heljasvaara R, Nyberg P, Luostarinen J, Parikka M, Heikkila P, Rehn M, Sorsa T, Salo T, Pihlajaniemi T. 2005. Generation of biologically active endostatin fragments from human collagen XVIII by distinct matrix metalloproteases. Exp Cell Res 307: 292304.

Hetzel M, Bachem M, Anders D, Trischler G, Faehling M. 2005. Different effects of growth factors on proliferation and matrix production of normal and fibrotic human lung fibroblasts. Lung 183: 225-37.

Higazi TB, Pearlman E, Whikehart DR, Unnasch TR. 2003. Angiogenic activity of an Onchocerca volvulus Ancylostoma secreted protein homologue. Mol Biochem Parasitol 129: 61-68

Horiuchi T, Weller PF, 1997. Expression of vascular endothelial growth factor by human eosinophils: upregulation by granulocyte macrophage colony-stimulating factor and interleukin-5. Am J Respir Cell Mol Biol 17: 70-7.

Hyder SM, Stancel GM, 1999. Regulation of angiogenic growth factors in the female reproductive tract by estrogens and progestins. Mol Endocrinol 13:806-11.

Ikuno Y, Hibino S, Bando H, Kawasaki Y, Nakamura T, Tano Y. 2002. Retinal glial cells stimulate microvascular pericyte proliferation via fibroblast growth factor and platelet-derived growth factor in vitro. Jpn J Ophtalmol 46: 413-18.

Kanse SM, Liang O, Schubert U, Haas H, Preissner KT, Doenhoff MJ, Dennis RD. 2005. Characterisation and partial purification of Schistosoma mansoni egg-derived pro-angiogenic factor. Mol Biochem Parasitol 144: 76-85

Klagsbrun M, Takashima S, Mamluk R. 2002. The role of neuropilin in vascular and tumor biology. Adv Exp Med Biol 515: 33-48

Klerkx EPF, Alarcón P, Waters K, Reinke V, Sternberg PW, Askjaer P, 2009. Protein kinase VRK-1 regulates cell invasion and EGL-17/FGF signaling in Caenorhabditis elegans. Dev Biol 335:12-21

Ko RC, Fan L, Lee DL, Compton H. 1994. Changes in host muscles induced by excretory/secretory products of larval Trichinella spiralis and Trichinella pseudospiralis. Parasitology 108 (Pt 2):195-205.

Ladomery MR, Harper SJ, Bates DO. 2007. Alternative splicing in angiogenesis: the vascular endothelial growth factor paradigm. Cancer Lett 249:133-42. 
Leung DW, Cachianes G, Kuang WJ, Goeddel DV, Ferrara N. 1989. Vascular endothelial growth factor is a secreted angiogenic mitogen. Science 246:1306-9.

Liao D, Johnson RS. 2007. Hypoxia: a key regulator of angiogenesis in cancer. Cancer Metastasis Rev 26:281-90

Lo TW, Branda CS, Huang P, Sasson IE, Goodman SJ, Stern MJ. 2008. Different isoforms of the $C$. elegans FGF receptor are required for attraction and repulsion of the migrating sex myoblasts. Dev Biol 318:268-275

Loeffler DA, Lundy SK, Singh KP, Gerard HC, Hudson AP, Boros DL. 2002. Soluble egg antigens from Schistosoma mansoni induce angiogenesis-related processes by up-regulating vascular endothelial growth factor in human endothelial cells. J Infect Dis 11: $1650-56$

Neufeld G, Cohen T, Gengrinovitch S, Poltorak Z. 1999. Vascular endothelial growth factor (VEGF) and its receptors. FASEB J 13: 9-22.

Nishi J, Maruyama I. 2000. Increased expression of vascular endothelial growth factor (VEGF) in Castleman's disease: proposed pathomechanism of vascular proliferation in the affected lymph node. Leuk Lymphoma 38: 387-94

Novo E, Cannito S, Zamara E, Valfre di Bonzo L, Caliguri A, cravanzola C, Compagnone A, Colombatto S, Marra F, Pinzani M, Parola M. 2007. Proangiogenic cytokines as hypoxia-dependent factors stimulating migration of human hepatic stellate cells. Am J Pathol 170: 1942-53

Nugent MA, Iozzo RV, 2000. Fibroblast growth factor-2 Int J. Biochem Cell Biol 32: 115-120.

Nurcombe V, Ford MD, Wildschut JA, Bartlett PF. 1993 Developmental regulation of neural response to FGF-1 and FGF-2 by heparan sulfate proteoglycan. Science 260: 103-106

O’Reilly MS, Boehm T, Shing Y, Fukai N, Vasios G, Lane WS, Flynn E, Birkhead JR, Olsen BR, Folkman J. 1997. Endostatin: an endogenous inhibitor of angiogenesis and tumor growth. Cell 88: 277-285.

Olsson AK, Johansson I, Akerud H, Einarsson B, Christofferson R, Sasaki T, Timpl R, Claesson-Welsh L. 2004. The minimal active domain of endostatin is a heparinbinding motif that mediates inhibition of tumor vascularization. Cancer Res 64: 9012-9017 
Olwin BB, Arthur K, Hannon K, Hein P, McFall A, Riley B, Szebenyi G, Zhou Z, Zuber ME, Rapraeger AC, et al. 1994. Role of FGFs in skeletal muscle and limb development. Mol Reprod Dev 39: 90-100

Otrock ZK, Makarem JA, Shamseddine AI. 2007. Vascular endothelial growth factor family of ligands and receptors: review. Blood Cells Mol Dis 38:258-68.

Pearce EJ, Kane C, Sun J, Taylor J, McKee AS, Cervi L. 2004. Th2 response polarization during infection with the helminth parasite Schistosoma mansoni. Immunol Rev 201: 117-26.

Persano L, Crescenzi M, Indraccolo S. 2007. Anti-angiogenic gene therapy of cancer: Current status and future prospects. Mol Asp Med 28:87-114.

Pfarr KM, Debrah AY, Specht S, Hoerauf A. 2009. Filariasis and lymphoedema. Parasite Immunol 31: 664-72.

Restrepo BI, Álvarez JI, Castaño JA, Arias LF, Restrepo M, Trujillo J, Colegial CH, Teale JM, 2001. Brain granulomas in neurocysticercosis patients are associated with a Th1 and Th2 profile. Infect Immun 69: 4554-60.

Ribatti D. 2009 Endogenous inhibitors of angiogenesis: A historical review. Leuk Res 33:638-644.

Ribatti D. 2005. The crucial role of vascular permeability factor/vascular endothelial growth factor in angiogenesis: a historical review. Br J Haematol 128: 303-9.

Richter AG, Maughan EO, Perkins GD, Nathani N, Thickett DR, 2005. VEGF levels in pulmonary fibrosis. Thorax 60: 171

Ritter DM, McKerrow JH. 1996. Intercellular adhesion molecule 1 is the major adhesion molecule expressed during schistosome granuloma formation. Infect Immun 64:4706-13

Rutitzky LI, Hernandez HJ, Yim YS, Ricklan DE, Finger E, Mohan C, Meter I, Wakeland EK, and Stadecker MJ. 2005. Enhanced egg-induced immunopathology correlates with high IFN-gamma in murine schistosomiasis: identification of two epistatic genetic intervals. J Immunol 174, 435-440.

Salven P, Hattori K, Heissig B, Rafii S, 2002. Interleukin-1 alpha promotes angiogenesis in vivo via VEGFR-2 pathway by inducing inflammatory cell VEGF synthesis and secretion. FASEB J 16: 1471-3. 
Sathornsumetee S, Rich JN. 2007. Antiangiogenic therapy in malignant glioma: promice and challenge. Curr Pharm Des 13: 3545-58.

Schlessinger J. 2000. Cell signaling by receptor tyrosine kinases. Cell 103:211-25.

Semenza GL. 1998. Hypoxia-inducible factor 1: master regulador of $\mathrm{O}_{2}$ homeostasis. Curr Opin Genet Dev 8: 588-594

Smith RJ, Cotter TP, Williams JF, Guderian RH. 1988. Vascular perfusion of Onchocerca volvulus nodules. Trop Med Parasitol 39 Suppl 4: 418-21

Senger DR, Galli SJ, Dvorak AM, Perruzzi CA, Harvey VS, Dvorak HF. 1983. Tumor cells secrete a vascular permeability factor that promotes accumulation of ascites fluid. Science 219: 983-5.

Shibuya M. 2001. Structure and function of VEGF/VEGF-receptor system involved in angiogenesis. Cell Struct Funct 26: 25-35

Shibuya M. 2003. Vascular endothelial growth factor receptor-2: its unique signaling and specific ligand, VEGF-E. Cancer Sci 94: 751-6.

Silva LM, Ribeiro dos Santos R, Soares MB, Andrade ZA. 2006. Characterization of the vascular changes in schistosomal portal (pipestem) fibrosis of mice. Acta Trop 98: $34-42$

Sund M, Hamano Y, Sugimoto H, Sudhakar A, Soubasakos M, Yerramalla U, Benjamin LE, Lawler J, Kieran M, Shah A, Kalluri R. 2005 Function of endogenous inhibitors of angiogenesis as endothelium-specific tumor suppressors. Proc Natl Acad Sci U.S.A. 102: 2934-2939

Tarsitano M, De Falco S, Colonna V, McGhee JD, and Persico MG. 2006. The $C$. elegans $p v f-1$ gene encodes a PDGF/VEGF-like factor able to bind mammalian VEGF receptors and to induce angiogenesis. FASEB J 20:227-233

Tawfeek GM, Alafifi AM, and Azmy MF. 2003. Immunological indicators of morbidity in human Schistosomiasis mansoni: role of vascular endothelial growth factor and anti-soluble egg antigen IgG4 in disease progression. J Egypt Soc Parasitol 33, 597614.

Tokunaga Y, Yamazaki Y, Morita T. 2005. Specific distribution of VEGF-F in Viperinae snake venoms: isolation and characterization of a VGEF-F from the venom of Daboia russelli siamensis. Arch Biochem Biophys 439: 241-7. 
Tsai HC, Liu YC, Lee SS, Chen ER, Yen CM. 2007. Vascular Endothelial Growth Factor is associated with blood brain barrier dysfunction in eosinophilic meningitis caused by Angiostrongylus cantonensis infection. Am J Trop Med Hyg 76: 592-95

Utton MA, Eickholt B, Howell FV, Wallis J, Doherty P. 2001. Soluble N-cadherin stimulates fibroblast growth factor receptor dependent neurite outgrowth and $\mathrm{N}$ cadherin and the fibroblast growth factor receptor co-cluster in cells. $\mathrm{J}$ Neurochem 76:1421-30.

Van de Vijver KK, Colpaert CG, Jacobs W, Kuypers K, Hokke CH, Deelder AM, Mark EV. 2006. The host's genetic background determines the extent of angiogenesis induced by schistosome egg antigens. Acta Trop 9: 243-251

Van Hensbergen Y, Broxterman HJ, Hanemaaijer R, Jorna AS, van Lent NA, Verheul HMV, Pinedo HM, Hoekman K. 2002 Soluble aminopeptidase N/CD13 in malignant and nonmalignant effusions and intratumoral fluid. Clin Cancer Res. 8:3747-3754

Wu JC, Yan HC, Chen WT, Chen WH, Wang CJ, Kao WY. 2008. JNK signaling pathway is required for bFGF-mediated surface cadherin downregulation on HUVEC. Exp Cell Res 314:421-9.

Yamaguchi N, Anand-Apte B, Lee M, Sasaki T, Fukai N, Shapiro R, QueI Lowik C, Timpl R, Olsen BR. 1999 Endostatin inhibits VEGF-induced endothelial cell migration and tumor growth independently of zinc binding. EMBO J. 18:4414-4423

Zachary I, Gliki G, 2001. Signaling transduction mechanisms mediating biological actions of the vascular endothelial growth factor family, Cardiovasc Res 49: 568581.

Zcharia E, Metzger S, Chajek-Shaul T, Friedmann Y, Pappo O, Aviv A, et al. 2001. Molecular properties and involvement of heparanase in cancer progression and mammary gland morphogenesis. J Mammal Gland Biol Neoplasis 6: 311-22. 


\section{Hypothesis and objetives}


In the previous review we observed that: $(i)$ angiogenesis is an important process of new blood vessel formation not only in tumor diseases but also in the pathogenesis of other diseases, specifically due to helminths (ii) studies on the role of angiogenesis in disesases due to helminths are scarce (iii) there is no bibliographical information on the production of angiogenic factors by macrophages or the use of anti-angiogenic factors in helminth infections (iv) although it has demonstrated the role of nitric oxide in these diseases and there is a documented relationship between nitric oxide and VEGF and other angiogenic agents, there is no specific bibliographical information about the interaction of both inflammatory mediators in these parasitic diseases.

The objectives proposed in this Thesis doctoral are:

1 .- To evaluate the expression of angiogenic factors (VEGF and FGF2) in alveolar macrophages stimulated with different antigens from different stages of the life cycle of Trichinella spiralis, Trichinella pseudospiralis, Strongyloides venezuelensis and Schistosoma mansoni.

2. - To study the relationship between the expression of angiogenic factors and nitric oxide production using specific inhibitors of inducible nitric oxide synthase.

3. - Using in vitro models of helminth infections to evaluate the effect of anti-angiogenic factors (endostatin).

4. - Using experimental models of infection the strongyloidosis S. venezuelensis and schistosomiasis by Schistosoma mansoni to evaluate the effect of anti-angiogenic factors in the development of the disease, studying the mechanisms that may be involved.

5. - To analyze the production of angiogenic factors in sera of patients diagnosed with imported diseases due to helminths. 
3 Investigation articles 


\subsection{Article 1.}

Trichinella: Differential expression of angiogenic factors in macrophages stimulated with antigens from encapsulated and non-encapsulated species

Shariati F, Pérez-Arellano JL, López Abán J, Arefi M, Martínez Fernández AR, Muro A. Experimental Parasitology 2009; 123:347-353 


\title{
Trichinella: Differential expression of angiogenic factors in macrophages stimulated with antigens from encapsulated and non-encapsulated species
}

\author{
F. Shariati ${ }^{a}$, J.L. Pérez-Arellano ${ }^{b}$, J. López-Abán ${ }^{a}$, M. Arefi ${ }^{c}$, A.R. Martínez-Fernández ${ }^{\text {d }}$, A. Muro ${ }^{\mathrm{a}, *}$ \\ a Laboratorio de Inmunología y Parasitología Molecular, CIETUS, Facultad de Farmacia, Universidad de Salamanca, 37007 Salamanca, Spain \\ ${ }^{\mathrm{b}}$ Departamento de Ciencias Médicas y Quirúrgicas, Facultad de Ciencias de la Salud, Universidad de Las Palmas de Gran Canaria, 35080 Las Palmas de Gran Canaria, Spain \\ 'Servicio de Hematología, Hospital Clínico Universitario, Salamanca, Spain

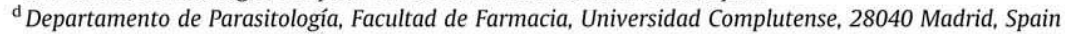

\section{A R T I C L E I N F O}

\section{Article history:}

Received 30 April 2009

Received in revised form 2 July 2009

Accepted 25 August 2009

Available online 31 August 2009

\section{Keywords:}

Vascular endothelial growth factor

Fibroblast growth factor

Nitric oxide

Alveolar macrophages

Trichinella sp.

Parasite antigens

\begin{abstract}
A B S T R A C T
The newborn larval stage of Trichinella spiralis enters the host striated skeletal muscle cell resulting in the formation of the nurse cell. Vascular Endothelial Growth Factor (VEGF) was detected in cells in the area immediately surrounding the nurse cells. However, no data are available on the antigens involved, the role of other angiogenic factors or the relationship of angiogenesis with Nitric Oxide (NO) production.

Using macrophage cell culture we study the effect of different Trichinella L1 antigens from one encapsulated (T. spiralis) and one non-encapsulated (Trichinella pseudospiralis) on the expression of VEGF and basic Fibroblast Growth Factor (FGF2). Also, we investigate the relationship between the production of NO and angiogenic mediators. The results show that encapsulated and non-encapsulated Trichinella species are different in their capacity to stimulate the expression of VEGF and FGF2 from host macrophages. Finally, there is no relationship between angiogenic factors and NO production by $T$. spiralis antigen.
\end{abstract}

Published by Elsevier Inc.

\section{Introduction}

Angiogenesis, the process of new blood vessel formation from pre-existing ones, plays a key role in various physiological and pathological conditions, including embryonic development, wound repair, tumour growth and inflammation (Carmeliet and Jain, 2000). Angiogenesis is a multi-step process that begins with the degradation of the basement membrane by activated endothelial cells that will migrate and proliferate leading to the formation of solid endothelial cell sprouts in the stromal space. Then, vascular loops are formed and capillary tubes develop with formation of tight junctions and deposition of new basement membrane. Numerous inducers of angiogenesis have been identified, including the members of the vascular endothelial growth factor (VEGF) family, angiopoietins, transforming growth factor- $\alpha$ and $-\beta$ (TGF- $\alpha$ and $-\beta$ ), platelet-derived growth factor (PDGF), tumour necrosis factor- $\alpha$ (TNF- $\alpha$ ), cytokines, chemokines and the fibroblast growth factor (FGF) family.

Vascular endothelial growth factor A (VEGFA) is a protein which in humans is encoded by the VEGFA gene, which is organized as eight exons separated by seven introns (Houck et al., 1991; Tischer et al.,

\footnotetext{
* Corresponding author. Address: Laboratorio de Inmunología y Parasitología Molecular, CIETUS, Facultad de Farmacia, Universidad de Salamanca, Avda. Campo Charro, s/n., 37007 Salamanca, Spain. Fax: +34 923294515.

E-mail address: ama@usal.es (A. Muro).
}

1991). Alternative exon splicing was initially shown to result in the generation of four different isoforms $\left(\mathrm{VEGF}_{121}, \mathrm{VEGF}_{165}, \mathrm{VEGF}_{189}\right.$, VEGF $_{206}$ ), having, respectively, 121, 165, 189 and 206 amino acids, after signal sequence cleavage. $\mathrm{VEGF}_{165}$, the predominant isoform, lacks the residues encoded by exon 6 , whereas $V_{E G F}{ }_{121}$ lacks the residues encoded by exons 6 and 7. Less frequent splice variants have been also reported, such as VEGF $_{145}$ and VEGF $_{183}$ (Neufeld et al., 1999). The VEGF gene has also been cloned in mouse and rat (Pagès and Pouysségur, 2005). The importance of a region of $1.2 \mathrm{~kb}$ was demonstrated for the mouse and the rat gene, while a bigger region of $2.362 \mathrm{~kb}$ was investigated in the human gene.

To date, more than 1200 PubMed-referenced papers related to FGFs and fibroblast growth factor receptors (FGFRs) in endothelial cells and during neovascularization have been published. FGF is found in almost all organs of the body and has been reported to play a fundamental role in various physiological processes, including growth, differentiation and injury repair. Basic fibroblast growth factor (FGF2), in particular, has been studied extensively. A major biological effect of FGF2 is induction of proliferation in cultured cells, including fibroblasts, endothelial cells and vascular smooth muscle cells (Klagsbrun and Edelman, 1989). As stated above, FGFs exert their biological activities by binding to high affinity tyrosine kinase FGFRs on the surface of target cells. In vitro, endothelial cells of different origin express FGFR1 (Bastaki et al., 1997; Javerzat et al., 2002) and, under some circumstances, FGFR2 
(Dell'Era et al., 2001), whereas the expression of FGFR3 or FGFR4 has never been reported in endothelium. Only a limited number among the 22 members of the FGF family have been investigated for their angiogenic potential in vitro and in vivo, the bulk of experimental data referring to the prototypic FGF1 and FGF2.

Nematode worms of the genus Trichinella are one of the most widespread zoonotic pathogens in the world. Infection by Trichinella sp. has been detected in domestic and/or wild animals of all continents, with the exception of Antarctica, where there is no record of the parasite (Pozio and Murrell, 2006). This global distribution of Trichinella, together with different cultural eating habits, represents the main factor favouring human infections in industrialised and non-industrialised countries. Major political and economic changes, revolutions and wars can contribute to an increase in prevalence among the human population (Murrell and Pozio 2000; Bolpe and Boffi, 2001; Marinculic et al., 2001; Djordjevic et al., 2003). Previously, all Trichinella infections occurring in animals and humans were attributed to Trichinella spiralis. Today, eight species ( $T$. spiralis, Trichinella nativa, Trichinella britovi, Trichinella pseudospiralis, Trichinella murrelli, Trichinella nelsoni, Trichinella papuae, and Trichinella zimbabwensis) and three genotypes (Trichinella T6, T8 and T9) within two clades (encapsulated and non-encapsulated) are recognised in this genus (Pozio and Murrell, 2006).

In the majority of situations in which a new vessel forms, a hypoxic event initiates the process (Fong, 2008). Cells in the immediate vicinity of reduced oxygen tension, e.g., inflammatory and interstitial cells in connective tissue, up-regulate and secrete angiogenic cytokines (Brindle, 1993), the most important of which is vascular endothelial growth factor (VEGF). The newborn larval stage of $T$. spiralis enters the host striated skeletal muscle cell resulting in the formation of the nurse cell. VEGF was detected in cells in the area immediately surrounding the nurse cells and the continued presence of VEGF in nurse cells could maintain the constant state of hypoxia (Capo et al., 1998). In a previous study in our laboratory, we have demonstrated that T. pseudospiralis and T. spiralis induced the basal and stimulated NO production, respectively (Andrade et al., 2007).

The aim of the present work is to examine the effect of encapsulated and non-encapsulated Trichinella antigens on VEGF and FGF2 expression from macrophage cells. Moreover, we study the relationship between angiogenic factors and NO production using inhibitory molecules analogues of L-arginine.

\section{Material and methods}

\subsection{Parasites and antigen preparation}

Crude somatic extracts were prepared from T. spiralis(STs)(MFEL/ SP/62/ISS48, GM-1) and T. pseudospiralis (STps) (MPRO/SU/72/ISS13) L1 as described earlier (Dea-Ayuela et al., 2001). Briefly, L1 larvae of $T$. spiralis and $T$. psuedospiralis were collected after artificial digestion of the carcasses of mice experimentally infected. Once washed ten times in PBS buffer, they were disrupted in a manual glass homogeniser followed by sonication $10 \mathrm{~s} /$ pulse in a Virsonic 5 . The homogenised product was allowed to extract over night at $4{ }^{\circ} \mathrm{C}$ and then centrifuged at $20.000 \mathrm{~g}$ for $30 \mathrm{~min}$. The supernatant was collected and dialysed overnight at $4{ }^{\circ} \mathrm{C}$ against PBS. Protein concentrations in the resulting extracts were estimated using the Micro-BCA protein assay reagent kit (Pierce, Rockford, Illinois, USA). The antigens were aliquoted and stored at $-20^{\circ} \mathrm{C}$ until use.

\subsection{Isolation of alveolar macrophages}

Male Wistar rats weighing $250-300 \mathrm{~g}$, from the Experimental Animal Service of the University of Salamanca were used for all experiments. Principles of Laboratory Animal Care, formulated by the National Society for Medical Research were used as guidelines for the use and care of animals. Alveolar macrophages were obtained by bronchoalveolar lavage as previously described (Espinoza et al., 2002). Briefly, a total of $15 \mathrm{ml}$ of pyrogen free saline solution was instilled in five aliquots $(3 \times 4 \mathrm{ml})$ using a Teflon catheter (Becton Dickinson SA, San Agustin del Guadalix, Spain). The recovered fluid was filtered through sterile gauze and then centrifuged at $250 \mathrm{~g}$ for 10 min at $4{ }^{\circ} \mathrm{C}$ and the supernatant was separated from the cell pellet. The latter was washed twice with PBS ( $\mathrm{pH} 7.4)$ and the cells were resuspended at a concentration of $1 \times 10^{6} / \mathrm{ml}$.

\subsection{Macrophage culture}

Alveolar macrophages were cultured as previously described (Espinoza et al., 2002). The cells were resuspended in Dulbecco's Modified Eagle Medium (DMEM) supplemented with 10\% fetal bovine serum $\gamma$-irradiated (Sigma Chemical Co, St. Louis, MO) treated for $30 \mathrm{~min}$ at $56^{\circ} \mathrm{C}, 2 \mathrm{mM}$ glutamine (Sigma), $100 \mathrm{U} / \mathrm{ml}$ of penicillin and $100 \mu \mathrm{g} / \mathrm{ml}$ of streptomycin (Sigma). Alveolar macrophages $\left(1 \times 10^{6} /\right.$ well) were plated on culture plates (Costar, Cambridge, $\mathrm{MA}$, USA) and allowed to adhere for $2 \mathrm{~h}$ at $37^{\circ} \mathrm{C}$ in $5 \% \mathrm{CO}_{2}$. Nonadhering cells were removed by gentle washing with complete medium and $1 \mathrm{ml}$ of fresh complete medium was added for further cell culture. Alveolar macrophages were incubated alone (negative control, ø), with $10 \mu \mathrm{g} / \mathrm{ml}$ of lipopolysaccharide (LPS) (positive control) (Sigma) and different concentrations $(0.1-50 \mu \mathrm{g} / \mathrm{ml})$ of STs. After $18 \mathrm{~h}$ at $37^{\circ} \mathrm{C}$ in $5 \% \mathrm{CO}_{2}$, the supernatant was collected, centrifuged at $500 \mathrm{~g}$ for $10 \mathrm{~min}$ and stored at $-80^{\circ} \mathrm{C}$ until analysis. After removing the supernatant for nitrite determination, the cell viability was assessed by the mitochondrial reduction of MTT (3-[4, 5-dimethylthiazol-2-yl]-2.5-diphenyl tetrazolium bromide) (Sigma) to formazan as described by Kiemer and Vollmar (1997). Briefly, the alveolar macrophages were incubated with MTT $(0.5 \mathrm{mg} / \mathrm{ml})$ for $1 \mathrm{~h}$ at $37^{\circ} \mathrm{C}$ and solubilised in dimethyl sulfoxide (DMSO) (Sigma). The extent of formazan production was determined photometrically at $550 \mathrm{~nm}$. Following this, alveolar macrophages were also recovered, aliquoted and stored at $-80^{\circ} \mathrm{C}$ until analysis.

\subsection{Detection of VEGF in rat alveolar macrophages by RT-PCR}

Total RNA was extracted from alveolar macrophages using an RNeasy Mini Kit (Qiagen GmbH, Hilden Germany). A total of $1 \mu \mathrm{g}$ RNA was used as template for the first-strand DNA synthesis (Roche). Primers specific for rat VEGF were designed according to (Yang et al., 2004; Liu et al., 2003). Primer sequence for VEGF was: sense, 5'-CTGCTCTCTTGGGTGCACTGG- ${ }^{\prime}$ ' and anti-sense, 5'-CACC GCCTTGGCTTGTCACAT- $3^{\prime}$, generating three bands of 601,540 and $408 \mathrm{bp}$, corresponding to VEGF isoforms of 188,164 and 120 amino acids; Glyceraldehyde 3-phosphate dehydrogenase (GAPDH) sense, 5'-GGTCGGTGTGAACGGATTTG-3' and GAPDH anti-sense, 5'-GTG AGCCCCAGCCTTCTCCAT- $3^{\prime}$ generating a 452 base pairs (bp) PCR product. PCR reactions were carried out through reverse transcription incubation at $94^{\circ} \mathrm{C}$ for $5 \mathrm{~min}, 35$ cycles of $94^{\circ} \mathrm{C}$ for $1 \mathrm{~min}$, $55^{\circ} \mathrm{C}$ for $1 \mathrm{~min}, 72{ }^{\circ} \mathrm{C}$ for $1 \mathrm{~min}$ and a single cycle at $72{ }^{\circ} \mathrm{C}$ for $7 \mathrm{~min}$. PCR products were analysed by electrophoresis in $2 \%$ agarose gel stained with ethidium bromide and quantification of RT-PCR products (VEGF and GAPDH) was carried out by densitometry with ImageJ computer program, available at http://rsb.info.nih.gov/ij/. The cDNA bands for VEGF were isolated from the gel, cloned into the PGEMT vector and sequenced in an automated sequencing system (ABI Prism 3100 Genetic Analyzer, Applied Biosystems) using universal and reverse primers. The sequences where compared with National Center for Biotechnology Information (NCBI) nucleotide BLAST searches (http://www.ncbi.nlm.nih.gov/BLAST). All experiments at least have been done by triplicate. 


\subsection{Detection of VEGF by ELISA}

Soluble VEGF levels in supernatant of alveolar macrophage cultures were detected with the RayBio ${ }^{\circledast}$ Rat VEGF ELISA Kit (Ray Biotech, Inc, Norcross GA, USA) according to the protocol suggested by the manufacturer.These determinations were performed in duplicate culture and three fold measures. The concentration of VEGF was calculated from standard curves using known concentrations of rat recombinant VEGF.

\subsection{Detection of FGF2 in alveolar macrophages by RT-PCR}

Total RNA was extracted from the alveolar macrophages using an RNeasy Mini Kit (Qiagen Inc.). A total of $1 \mu \mathrm{g}$ RNA was used as template for the first-strand DNA synthesis. Primers specific for rat FGF2 were designed according to Jyo-Oshiro et al. (1999). Primer sequence for FGF2 was: sense, 5'GCCGGCAGCATCACTTCGC T-3' and anti-sense, 5'CTGTCCAGGCCCCGTTTTGG-3'. PCR reactions were carried out through reverse transcription incubation at $94{ }^{\circ} \mathrm{C}$ for $2 \mathrm{~min}, 50$ cycles of $94^{\circ} \mathrm{C}$ for $30 \mathrm{~s}, 60^{\circ} \mathrm{C}$ for $30 \mathrm{~s}, 72{ }^{\circ} \mathrm{C}$ for $1 \mathrm{~min}$ and a single cycle at $72{ }^{\circ} \mathrm{C}$ for $5 \mathrm{~min}$. PCR products were analysed by electrophoresis in 1.5\% agarose gel stained with ethidium bromide. The quantification of RT-PCR product (FGF2) was carried out by densitometry as above. Also GAPDH was used as an internal control. The cDNA bands for FGF2 were isolated from the gel, cloned into the pGEMT vector and sequenced as above. All experiments at least have been done by triplicate.

\subsection{Inhibitors of NO production}

$\mathrm{N}^{\mathrm{w}}$-Nitro-L-arginine methyl ester (L-NAME; Affinity, UK) was used as an inhibitor of all nitric oxide synthase (NOS) isoforms and L-canavanine (Sigma Chemical Co) was used as a specific inhibitor of inducible nitric oxide synthase (iNOS); Both inhibitors (at a final concentration of $10^{-2} \mathrm{M}$ ) were used to assess the specificity of the induction of NO production by the $T$. spiralis antigen.

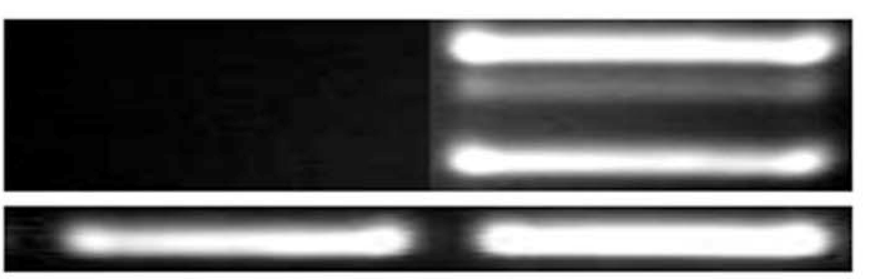

$\emptyset$

\section{LPS}

(bp)

601

540

408

452

GAPDH

Fig. 1. (A) Effect of lipopolysaccharide (LPS) on the VEGF production by alveolar macrophages. Ø: Non-stimulated macrophages LPS: LPS-stimulated macrophages (10 $\mu$ g/ml). (B) Sequence of VEGF fragments from LPS-stimulated macrophages (VEGF-a). The homology with Rattus norvegicus vascular endothelial growth factor A transcript variant 3 , mRNA, ACCN: NM 001110334.1 (VEGF-b) was $99 \%$. 


\subsection{Detection of VEGF by ELISA}

Soluble VEGF levels in supernatant of alveolar macrophage cultures were detected with the RayBio ${ }^{\circledast}$ Rat VEGF ELISA Kit (Ray Biotech, Inc, Norcross GA, USA) according to the protocol suggested by the manufacturer.These determinations were performed in duplicate culture and three fold measures. The concentration of VEGF was calculated from standard curves using known concentrations of rat recombinant VEGF.

\subsection{Detection of FGF2 in alveolar macrophages by RT-PCR}

Total RNA was extracted from the alveolar macrophages using an RNeasy Mini Kit (Qiagen Inc.). A total of $1 \mu \mathrm{g}$ RNA was used as template for the first-strand DNA synthesis. Primers specific for rat FGF2 were designed according to Jyo-Oshiro et al. (1999). Primer sequence for FGF2 was: sense, 5'GCCGGCAGCATCACTTCGC T- $3^{\prime}$ and anti-sense, 5'CTGTCCAGGCCCCGTTTTGG-3'. PCR reactions were carried out through reverse transcription incubation at $94{ }^{\circ} \mathrm{C}$ for $2 \mathrm{~min}, 50$ cycles of $94^{\circ} \mathrm{C}$ for $30 \mathrm{~s}, 60^{\circ} \mathrm{C}$ for $30 \mathrm{~s}, 72{ }^{\circ} \mathrm{C}$ for $1 \mathrm{~min}$ and a single cycle at $72{ }^{\circ} \mathrm{C}$ for $5 \mathrm{~min}$. PCR products were analysed by electrophoresis in 1.5\% agarose gel stained with ethidium bromide. The quantification of RT-PCR product (FGF2) was carried out by densitometry as above. Also GAPDH was used as an internal control. The cDNA bands for FGF2 were isolated from the gel, cloned into the pGEMT vector and sequenced as above. All experiments at least have been done by triplicate.

\subsection{Inhibitors of NO production}

$\mathrm{N}^{\mathrm{w}}$-Nitro-L-arginine methyl ester (L-NAME; Affinity, UK) was used as an inhibitor of all nitric oxide synthase (NOS) isoforms and L-canavanine (Sigma Chemical Co) was used as a specific inhibitor of inducible nitric oxide synthase (iNOS); Both inhibitors (at a final concentration of $10^{-2} \mathrm{M}$ ) were used to assess the specificity of the induction of NO production by the T. spiralis antigen.

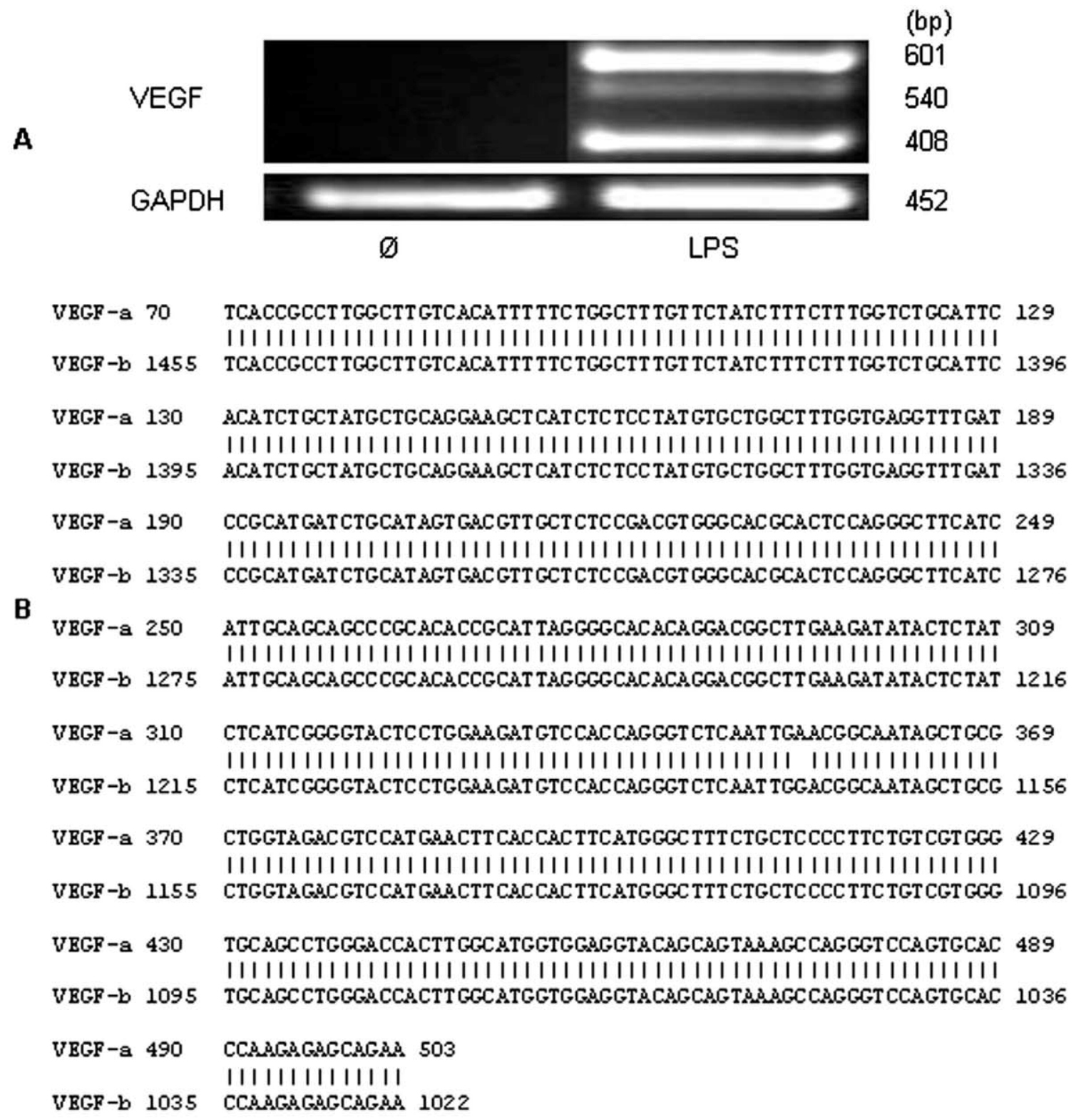

Fig. 1. (A) Effect of lipopolysaccharide (LPS) on the VEGF production by alveolar macrophages. Ø: Non-stimulated macrophages LPS: LPS-stimulated macrophages (10 $\mu$ g/ml). (B) Sequence of VEGF fragments from LPS-stimulated macrophages (VEGF-a). The homology with Rattus norvegicus vascular endothelial growth factor A transcript variant 3, mRNA, ACCN: NM 001110334.1 (VEGF-b) was $99 \%$. 
Polymyxin B, a specific inhibitor of NO production triggered by LPS, was used at $80 \mu \mathrm{g} / \mathrm{ml}$ to assess possible LPS derived contamination in the different antigenic preparations. All experiments at least have been done by triplicate.

\subsection{Statistical analysis}

The results of the VEGF protein detection were reported as arithmetic mean and standard error. Differences in groups were performed by analysis of variance (ANOVA). When global differences were detected, a post-ANOVA test using the Fisher LSD analysis was applied. Differences between means were considered statistically significant at $p<0.05$. All statistical analyses were performed using Statworks and Statview 4.5 software packages for a Macintosh computer.

\section{Results}

Three VEGF isoforms were detected in alveolar macrophages stimulated with $10 \mu \mathrm{g} / \mathrm{ml}$ of LPS by RT-PCR (Fig. 1A). Alveolar macrophages expressed three bands of 601,540 and $408 \mathrm{bp}$, corresponding to VEGF isoforms of 188, 164 and 120 amino acids. The PCR product was cloned in pGEMT vector and sequenced. This sequence presented 99 percent homology with VEGF from Rattus norvegicus (Fig. 1B).

Also FGF2 was detected in alveolar macrophages stimulated with $10 \mu \mathrm{g} / \mathrm{ml}$ of LPS by RT-PCR (Fig. 2A). Alveolar macrophages expressed a single band of $423 \mathrm{bp}$. The PCR product was cloned in pGEMT vector and sequenced. This fragment has 99 percent homology with FGF2 from Rattus norvegicus (Fig. 2B).

The effect of in vitro incubation of rat alveolar macrophages with different concentrations of $T$. spiralis antigens (STS) (0.1, $1.0,10$ and $50 \mu \mathrm{g} / \mathrm{ml}$ ) on expression of VEGF is shown in Fig $3 \mathrm{~A}$. The results indicate that LPS-stimulated macrophages $(10 \mu \mathrm{g} / \mathrm{ml})$ and macrophages stimulated with STs from $1 \mu \mathrm{g} / \mathrm{ml}$ induce VEGF mRNA expression in a dose-dependent manner until $10 \mu \mathrm{g} / \mathrm{ml}$ when compared with VEGF mRNA levels detected in non-stimulated macrophages. The effects of different concentrations of STs $(0.1,1.0,10$ and $50 \mu \mathrm{g} / \mathrm{ml})$ on expression of FGF2 in rat alveolar macrophages are shown in Fig 3B. The results

A

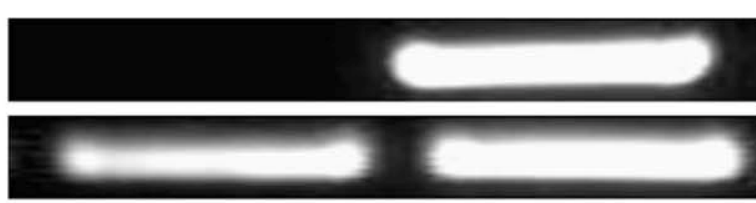

(bp)

423

452

$\emptyset$

LPS

FGR2-a 512

FGR2-b 538

FGF2-a 572

FGF2-b 598

FGF2-a 632

FGF2-b 658

B FGF2-a 692

FGF2-b 718

FGF2-a 752

FGF2-b 778

FGF2-a 812

FGF2-b 838

FGF2-a 872

FGF2-b 898

FGF2-a 932

FGF2-b 958
TGCCGGCAGCATCACTTCGCT TCCCGCACT GCCGGAGGACGGCGCGGCGCCTTCCCACC 571

111111111111111111111111111111111111111111111111111111111111 TGCCGGCAGCATCACTTCGCT TCCCGCACTGCCGGAGGACGGCGGCGGCGCCTTCCCACC 597

CGGCCACTTCAAGGA TCCCAAGCGGCTCTACTGCAAGAACGGCGCTTCTTCCTGCGCAT 631

||||||||||||||||||||||||||||||||||||||||||||||||||||||||||||

CGGCCACTT CAAGGA TCCCAAGCGGCTCTACTGCAAGAACGGCGGCTTCTTCCTGCGCAT 657

CCATCCAGACGGCCGCGT GGACGGCGTCCGGGAGAAGACGACCCACACGTCAAACTACA 691 IIIIIIIIIIIIIIIIIIIIIIIIIIIIIIIIIIIIIIIIIIIIIIIIIIIIIIIIIIII CCATCCAGACGGCCGCGT GGACGGCGTCCGGGAGA GAGCGACCCACACGTCAAACTACA 717

GCTCCAACCAGAAGAGAGAGGAGT TGT GTCCATCAAGGGAGT GTGTCCGAACCGGTACCT 751

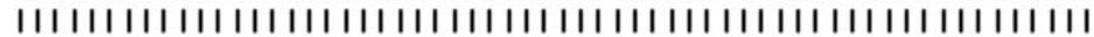
GCT CCA_GCAGAAGAGAGAGGAGT TGT GTCCATCAAGGGAGTGTGTGCGAACCGGTACCT 777

GGCTAT GAAGGAAGA TGGACGGCT GCT GGCTTCTAAGTGTGT TACAGAAGAGTGTTCCTT 811

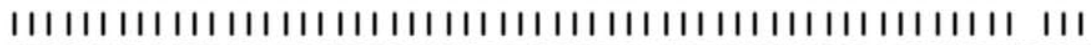
GGCTAT GAAGGAGA TGGACGGCTGCTGCCTTCTA.GTGTGT TACAGAAGAGTTTTCTT 837

CTT TGAACGCCTGGAGTCCAATAACTACAACACTTACCGGTCACGGAASACTCCAGTTG 871

|||||||||||||||||||||||||||||||||||||||||||||||||||||| CTT TGA_CGCCTGGAGTCCASTAACTACAACACTTACCGGTCACGGABATACTCCAGTTG 897

GTATGTGCCACTGAAACGACTGGGCAGTATAAACTCGGATCCAAAACGGGCCCTGGACA 931

|||||||||||||||||||||||||||||||||||||||||||||||||||||||||||| GTATGT GCCACT GA.ACGAACTGGGCAGTATAA_ACTCGGATCCAAAACGGGGCCTGGACA 957

GAS 934

III

Gas 960

Fig. 2. (A) Effect of lipopolysaccharide (LPS) on the FGF2 production by alveolar macrophages. Ø: Non-stimulated macrophages LPS: LPS-stimulated macrophages (10 $\mu \mathrm{g} / \mathrm{ml})$. (B) Sequence of FGF2 fragment from LPS-stimulated macrophages (FGF2-a). The homology with Rattus norvegicus fibroblast growth factor 2, mRNA, ACCN: NM 019305.2 (FGF2-b) was $99 \%$. 

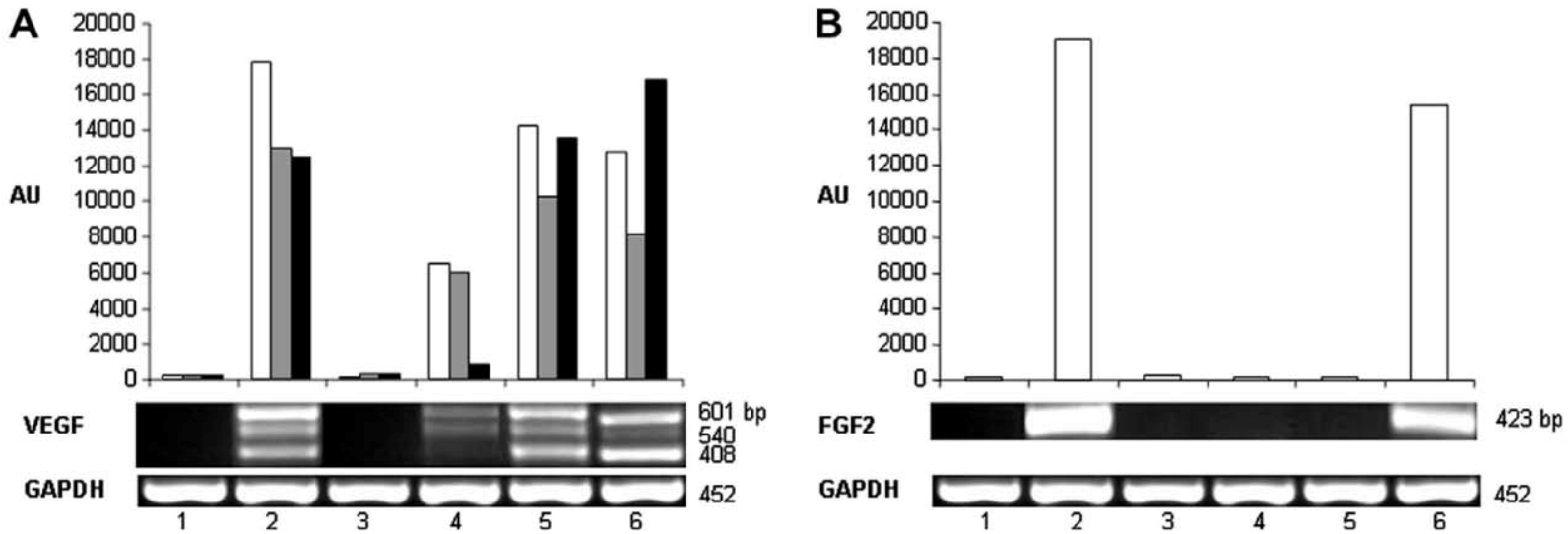

Fig. 3. (A) VEGF expression in rat alveolar macrophages induced by Trichinella spiralis (STs) antigen detected by RT-PCR. GAPDH mRNA expression levels from rat alveolar macrophages were used as internal control. (1) Non-stimulated macrophages (negative control), (2) LPS-stimulated macrophages (positive control), (3-6) STs-stimulated macrophages with $0.1,1,10$ and $50 \mu \mathrm{g} / \mathrm{ml}$. AU: arbitrary units calculated by densitometry of corresponding amplicons. 601 bp VEGF band (white bars), 540 bp VEGF band (grey bars) and 408 bp VEGF band (black bars). (B) FGF2 expression in rat alveolar macrophages induced by Trichinella spiralis (STs) antigen detected by RT-PCR. GAPDH mRNA expression levels from rat alveolar macrophages were used as internal control. (1) Non-stimulated macrophages (negative control), (2) LPS-stimulated macrophages (positive control), (3-6) STs-stimulated macrophages with $0.1,1,10$ and $50 \mu \mathrm{g} / \mathrm{ml}$. AU: arbitrary units calculated by densitometry of corresponding amplicons. 423 bp FGF2 band (white bars).
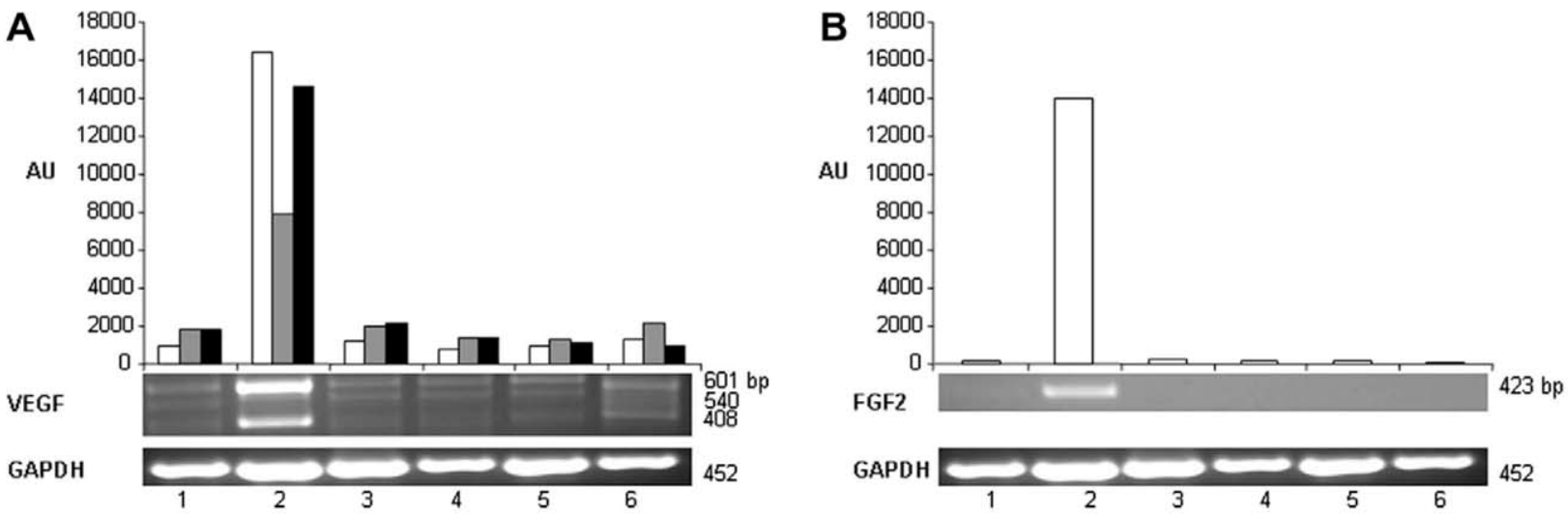

Fig. 4. (A) VEGF expression in rat alveolar macrophages induced by Trichinella pseudospiralis (STps) antigen detected by RT-PCR. GAPDH mRNA expression levels from rat alveolar macrophages were used as internal control. (1) Non-stimulated macrophages (negative control), (2) LPS-stimulated macrophages (positive control), (3-6) STpsstimulated macrophages with $0.1,1,10$ and $50 \mu \mathrm{g} / \mathrm{ml}$. AU: arbitrary units calculated by densitometry of corresponding amplicons. 601 bp VEGF band (white bars), 540 bp VEGF band (grey bars), 408 bp. (B) FGF2 expression in rat alveolar macrophages induced by Trichinella pseudospiralis (STps) antigen detected by RT-PCR. GAPDH mRNA expression levels from rat alveolar macrophages were used as internal control. (1) Non-stimulated macrophages (negative control), (2) LPS-stimulated macrophages (positive control), (3-6) STps-stimulated macrophages with $0.1,1,10$ and $50 \mu \mathrm{g} / \mathrm{ml}$. AU: arbitrary units calculated by densitometry of corresponding amplicons. 423 bp FGF2 band (white bars).

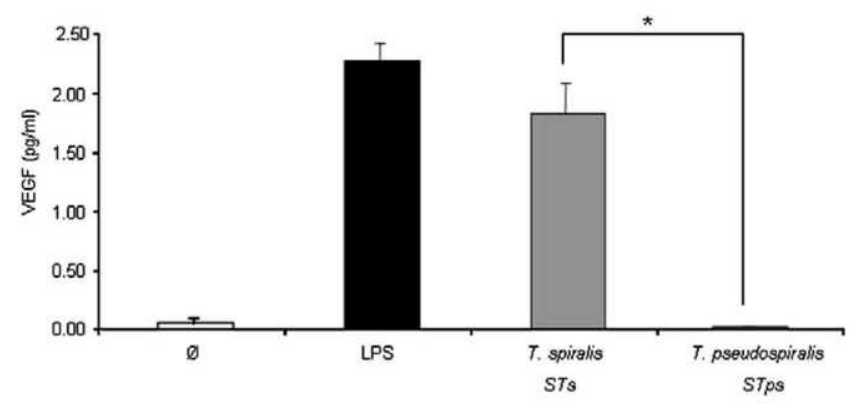

Fig. 5. VEGF protein detection in supernatant of alveolar rat macrophages cultures treated with L1 somatic antigen of T. spiralis (STS) T. pseudospiralis (STpS) and its controls not treated macrophages $(\emptyset)$ and lipopolysacharide treated macrophages (LPS). Means and SEM of six measures in duplicate culture. ${ }^{*} p<0.05$.

show that LPS-stimulated macrophages $(10 \mu \mathrm{g} / \mathrm{ml})$ and macrophages stimulated with only $50 \mu \mathrm{g} / \mathrm{ml}$ STs induce FGF2 mRNA expression.
In vitro incubation of rat alveolar macrophages with $T$. pseudospiralis antigens (STps) resulted in no stimulation of VEGF production by these cells, when compared with basal levels (Fig. 4A). Also FGF2 was not detected in alveolar macrophages stimulated with STps antigens (Fig 4B).

VEGF protein expression was confirmed by ELISA in supernatant of alveolar macrophages stimulated with STS and STps antigens. The results show that macrophages stimulated with STS had $1.86 \pm 0.25 \mathrm{pg}$ of VEGF/ $\mu \mathrm{g}$ of protein and macrophages stimulated with somatic STps had $0.02 \pm 0.01 \mathrm{pg}$ of $\mathrm{VEGF} / \mu \mathrm{g}$ of protein, with statistical differences $(p<0.05)$. When compared with macrophages stimulated with LPS had $2.31 \pm 0.15 \mathrm{pg}$ of $\mathrm{VEGF} / \mu \mathrm{g}$ of protein and $0.09 \pm 0.01 \mathrm{pg}$ of $\mathrm{VEGF} / \mu \mathrm{g}$ of protein in macrophages no stimulated (Fig. 5).

We studied the relationship between angiogenic factors and nitric oxide in macrophages stimulated with STs antigens, using specific inhibitors of inducible nitric oxide synthase (L-NAME and L-canavanine). The results show that L-NAME and L-canavanine did not produce low expression levels of VEGF (Fig. 6A) and FGF2 (Fig. 6B). 

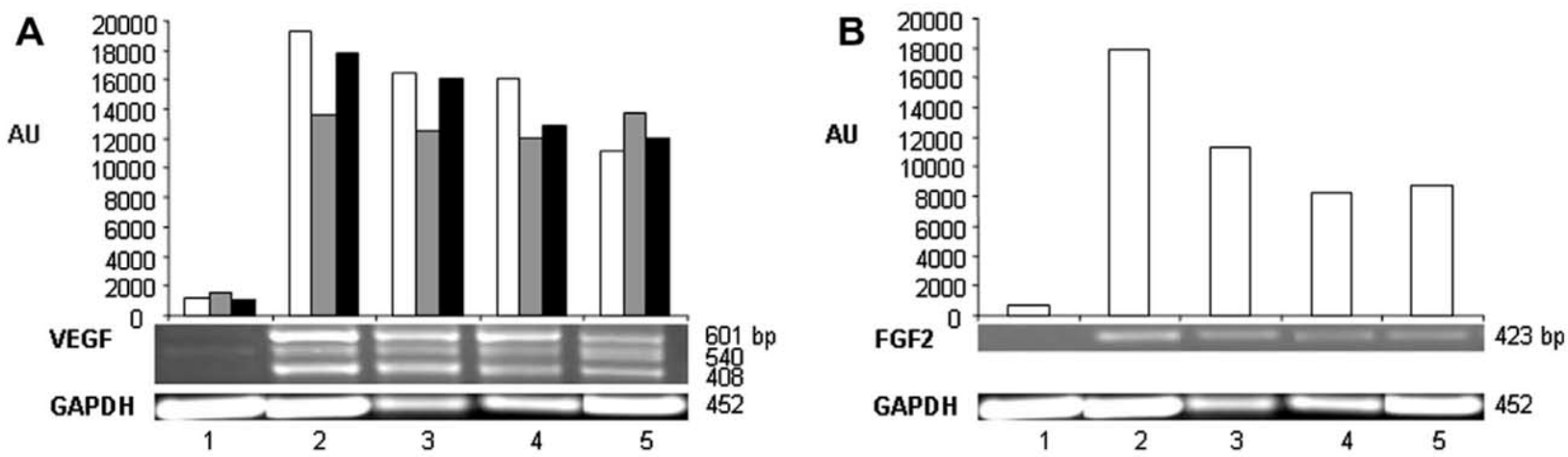

Fig. 6. (A) Effects of specific inhibitor of inducible nitric oxide synthase (iNOS) on VEGF mRNA expression of STs-stimulated macrophages. GAPDH mRNA expression levels from rat alveolar macrophages were used as internal control. (1) Non-stimulated macrophages (negative control), (2) LPS-stimulated macrophages (positive control), (3) STsstimulated macrophages $(50 \mu \mathrm{g} / \mathrm{ml})$. (4) STs-stimulated macrophages plus L-NAME $\left(50 \mu \mathrm{g} / \mathrm{ml}+10^{-2} \mathrm{M}\right)$. (5) STs-stimulated macrophages plus L-canavanine ( $50 \mu \mathrm{g} /$ $\mathrm{ml}+10^{-2} \mathrm{M}$ ). AU: arbitrary units calculated by densitometry of corresponding amplicons. 601 bp VEGF band (white bars), 540 bp VEGF band (grey bars), 408 bp. (B) Effects of specific inhibitor of inducible nitric oxide synthase (iNOS) on FGF2 mRNA expression of STs-stimulated macrophages. GAPDH mRNA expression levels from rat alveolar macrophages were used as internal control. (1) Non-stimulated macrophages (negative control), (2) LPS-stimulated macrophages (positive control), (3) STs-stimulated macrophages $(50 \mu \mathrm{g} / \mathrm{ml})$. (4) STs-stimulated macrophages plus L-NAME $\left(50 \mu \mathrm{g} / \mathrm{ml}+10^{-2} \mathrm{M}\right)$. (5) STs-stimulated macrophages plus L-canavanine $\left(50 \mu \mathrm{g} / \mathrm{ml}+10^{-2} \mathrm{M}\right)$. AU: arbitrary units calculated by densitometry of corresponding amplicons. 423 bp FGF2 band (white bars).

\section{Discussion}

The encapsulated species are characterised by deposition of collagen and other components of the extracellular matrix around the larvae of Trichinella (Wu et al., 2008). An associated key process to the fibrogenesis is the angiogenesis (Wynn, 2008). In fact, experimental data suggest that hypoxia in relation to VEGF may stimulate proliferation of synthesis of collagen type 1 in activated myofibroblast like cells (Novo et al., 2007).

Our results indicate that the macrophages are able to produce and to release not only VEGF but also FGF2 in response to antigens of encapsulated species like $T$. spiralis, in a dose-dependent manner. Gene expression of VEGF was determined by RT-PCR and protein expression measured by ELISA. Nevertheless, non-encapsulated species likes $T$. pseudospiralis were not able to induce the expression of these angiogenesis factors. The larva penetrates the muscle cell, grows in it and destroyed myofibrils. The satellite cells that surround the cell with muscle fibre undergo morphological changes transforming into nurse cells. Previously it has been demonstrated that the nurse cells are able to produce VEGF during the infection by T. spiralis, (Capo et al., 1998). In this paper we demonstrate that inflammatory cells that surround the injured muscle fibre contribute in the production of angiogenic factors. Probably, both cell types contributed to the development of the capsule of this species.

Previous studies of our group have demonstrated that antigens of encapsulated and non-encapsulated species of Trichinella were able to stimulate nitric oxide (NO) production (Andrade et al., 2007). As NO is an inductive factor for VEGF production (Namba et al., 2003), we evaluated whether the inhibition of NOS, by using the specific inhibitors L-NAME and L-canavanine, modified the effect of antigens of Trichinella on the production of angiogenesis factors. This study demonstrates that the effect of the antigens of $T$. spiralis does not depend on NO.

In summary, antigens from encapsulated species of Trichinella directly stimulated the production of angiogenic factors (VEGF and FGF2) that contributed to the pathogenesis of this nematode infection.

\section{Acknowledgments}

This work has been supported by Grant SA116A08 from the Junta de Castilla y León. Shariati F, doctoral student has been supported by fellowships from the Ministry of Science and Technology of I R of Iran.

\section{References}

Andrade, M.A., Siles-Lucas, M., Lopez-Aban, J., Nogal-Ruiz, J.J., Perez-Arellano, J.L., Martinez-Fernandez, A.R., et al., 2007. Trichinella: differing effects of antigens from encapsulated and non-encapsulated species on in vitro nitric oxide production. Vet. Parasitol. 143, 86-90.

Bastaki, M., Nelli, E.E., Dell'Era, P., Rusnati, M., Molinari-Tosatti, M.P., Parolini, S., et al., 1997. Basic fibroblast growth factor-induced angiogenic phenotype in mouse endothelium. A study of aortic and microvascular endothelial cell lines. Arterioscler. Thromb. Vasc. Biol. 17, 454-464.

Brindle, N.P., 1993. Growth factors in endothelial regeneration. Cardiovasc. Res. 27. $1162-1172$.

Bolpe, J., Boffi, R., 2001. Human trichinellosis in Argentina. Review of the casuistry registered from 1990 to 1999. Parasite 8, S78-S80.

Capo, V.A., Despommier, D.D., Polvere, R.I., 1998. Trichinella spiralis: vascular endothelial growth factor is up-regulated within the nurse cell during the early phase of its formation. J. Parasitol. 84, 209-214.

Carmeliet, P., Jain, R.K., 2000. Angiogenesis in cancer and other diseases. Nature 407, 249-257.

Dea-Ayuela, M.A., Ubeira, F.M., Pitarch, A., Gil, C., Martinez-Fernandez, A.R., Bolas, F., 2001. A comparison of antigenic peptides in muscle larvae of several Trichinella species by two-dimensional Western-blot analysis with monoclonal antibodies. Parasite 8, S117-S119.

Dell'Era, P., Belleri, M., Stabile, H., Massardi, M.L., Ribatti, D., Presta, M., 2001. Paracrine and autocrine effects of fibroblast growth factor- 4 in endothelial cells. Oncogene 20, 2655-2663.

Djordjevic, M., Bacic, M., Petricevic, M., Cuperlovic, K., Malakauskas, A., Kapel, C.M., et al., 2003. Social, political, and economic factors responsible for the reemergence of trichinellosis in Serbia: a case study. J. Parasitol. 89, 226231.

Espinoza, E., Muro, A., Martin, M.M., Casanueva, P., Perez-Arellano, J.L., 2002. Toxocara canis antigens stimulate the production of nitric oxide and prostaglandin E2 by rat alveolar macrophages. Parasite Immunol. 24, 311-319.

Fong, G.H., 2008. Mechanism of adaptative angiogenesis to tissue hypoxia. Angiogenesis 11, 121-140.

Houck, K.A., Ferrara, N., Winer, J., Cachianes, G., Li, B., Leung, D.W., 1991. The vascular endothelial growth factor family: identification of a fourth molecular species and characterization of alternative splicing of RNA. Mol. Endocrinol. 5, 1806-1814.

Javerzat, S., Auguste, P., Bikfalvi, A., 2002. The role of fibroblast growth factors in vascular development. Trends Mol. Med. 8, 483-489.

Jyo-Oshiro, Y., Sasaki, T., Kawakami, Y., Nohno, T., Itoh, N., Osawa, G., et al., 1999. Expression of the fibroblast growth factor receptor 1-4 genes in glomeruli in anti-Thy1.1 mesangial proliferative glomerulonephritis. Virchows Arch. 435 , 501-508.

Kiemer, A.K., Vollmar, A.M., 1997. Effects of different natriuretic peptides on nitric oxide synthesis in macrophages. Endocrinology 138, 4282-4290.

Klagsbrun, M., Edelman, E.R., 1989. Biological and biochemical properties of fibroblast growth factors. Implications for the pathogenesis of atherosclerosis. Arteriosclerosis 9, 269-278. 
Liu, M.Y., Poellinger, L., Walker, C.L., 2003. Up-regulation of hypoxia-inducible factor $2 \alpha$ in renal cell carcinoma associated with loss of Tsc- 2 tumor suppressor gene. Cancer Res. 63, 2675-2680.

Marinculic, A., Gaspar, A., Durakovic, E., Pozio, E., La Rosa, G., 2001. Epidemiology of swine trichinellosis in the Republic of Croatia. Parasite 8, S92-S94.

Murrell, K.D., Pozio, E., 2000. Trichinellosis: the zoonosis that won't go quietly. Int. J. Parasitol. 30, 1339-1349.

Namba, T., Koike, H., Murakami, K., Aoki, M., Makino, H., Hashiya, N., et al., 2003. Angiogenesis induced by endothelial nitric oxide synthase gene through vascular endothelial growth factor expression in a rat hindlimb ischemia model. Circulation 108, 2250-2257.

Neufeld, G., Cohen, T., Gengrinovitch, S., Poltorak, Z., 1999. Vascular endothelial growth factor (VEGF) and its receptors. FASEB J. 13, 9-22.

Novo, E., Cannito, S., Zamara, E., Valfre di Bonzo, L., Caligiuri, A., Cravanzola, C., et al., 2007. Proangiogenic cytokines as hypoxia-dependent factors stimulating migration of human hepatic stellate cells. Am. J. Pathol. 170, 1942-1953.
Pagès, G., Pouysségur, J., 2005. Transcriptional regulation of the Vascular Endothelial Growth Factor gene a concert of activating factors. Cardiovasc. Res. 65, 564-573. Pozio, E., Darwin Murrell, K., 2006. Systematics and epidemiology of trichinella. Adv. Parasitol. 63, 367-439.

Tischer, E., Mitchell, R. Hartman, T., Silva, M., Gospodarowicz, D., Fiddes, J.C., et al. 1991. The human gene for vascular endothelial growth factor. Multiple protein forms are encoded through alternative exon splicing. J. Biol. Chem. 266, $11947-$ 11954.

Wu, Z., Sofronic-Milosavljevic, L., Nagano, I., Takahashi, Y., 2008. Trichinella spiralis: nurse cell formation with emphasis on analogy to muscle cell repair. Parasit. Vectors 1,27

Wynn, T.A., 2008. Cellular and molecular mechanisms of fibrosis. J. Pathol. 214, 199-210.

Yang, Z.F., Ho, D.W., Chu, A.C., Wang, Y.Q., Fan, S.T., 2004. Linking inflammation to acute rejection in small-for-size liver allografts: the potential role of early macrophage activation. Am. J. Transplant. 4, 196-209. 


\subsection{Article 2.}

Role of angiogenic factors in acute experimental Strongyloides venezuelensis infection Fariborz Shariati, José Luis Pérez-Arellano, Julio López-Abán, Ahmed Mohamed El-Behairy, Antonio Muro.

Parasite Immunology (Acepted, 11 January 2010) 


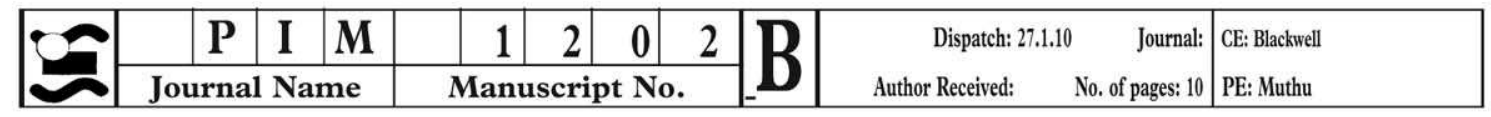

\title{
Role of angiogenic factors in acute experimental Strongyloides venezuelensis infection
}

\author{
F. SHARIATI, ${ }^{1}$ J. L. PÉREZ-ARELLANO ${ }^{2}$ J. LÓPEZ-ABÁN,${ }^{1}$ A. M. EL BEHAIRY ${ }^{3}$ \& A. MURO ${ }^{1}$ \\ ${ }^{1}$ Laboratorio de Inmunología y Parasitología Molecular, CIETUS, Facultad de Farmacia, Universidad de Salamanca, Salamanca, Spain, \\ ${ }^{2}$ Departamento de Ciencias Médicas y Quirúrgicas. Facultad de Ciencias de la Salud, Universidad de Las Palmas de Gran Canaria, Las \\ 11 Palmas de Gran Canaria, Spain, ${ }^{3}$ Faculty of Veterinary Medicine, Cairo University, Cairo, Egypt
}

\section{SUMMARY}

This study aims to investigate the role of angiogenic factors in the pathogenesis of experimental strongyloidiasis. Two complementary approaches were used: Firstly, CD1 mice were treated with endostatin, an angiogenesis inhibitor, and infected with Strongyloides venezuelensis. Also, the mechanisms involved in this process were studied. Parasitological examination revealed a significant decrease in egg per gram of faeces, number of collected larvae from lung tissue and number of collected adult females in mice treated with endostatin. Direct mechanisms with diminution of angiogenesis factors and an indirect mechanism with increase of eosinophil perhaps produced their effect. Secondly, the effect of the antigens responsible for stimulation of angiogenic factors [vascular endothelial growth factor (VEGF) and fibroblast growth factor 2 (FGF2)] from alveolar macrophages and the mechanisms involved in their production were investigated. Alveolar macrophage cells obtained by bronchoalveolar lavage were incubated at different concentrations of somatic and excretory/secretory antigens of $S$. venezuelensis. Also, mRNA levels of VEGF and FGF2 in macrophage cells were detected by RT-PCR. L3-PBS larvae antigens induced angiogenic factors. The relationship between angiogenesis factors and nitric oxide has been observed using nitric oxide synthase inhibitors.

Keywords endostatin, fibroblast growth factor (FGF2), nitric oxide, Strongyloides venezuelensis, vascular endothelial growth factor (VEGF)

Correspondence: Antonio Muro, Laboratorio de Inmunología y Parasitología Molecular, CIETUS, Facultad de Farmacia, Universidad de Salamanca, Avda. Campo Charro, s/n. 37007, Salamanca, Spain (e-mail: ama@usal.es).

Disclosures: None.

Received: $X x$ Xxxx 200X

Accepted for publication: 11 January 2010

\section{INTRODUCTION}

Strongyloides is a genus of parasitic nematodes which includes some 50 species of obligatory parasites of vertebrates. Two species of Strongyloides infect humans, Strongyloides stercoralis and Strongyloides fuelleborni (1). In healthy individuals, infection with Strongyloides can be clinically inapparent or can lead to cutaneous, gastrointestinal or pulmonary symptoms. However, Strongyloides infection in immunocompromized individuals (e.g. corticosteroid use and human T lymphotropic virus type I infection) can result in disseminated strongyloidiasis, in which worms move beyond the confines of the gut into other organs (2).

The lifecycle of Strongyloides is complicated and available data have been mainly obtained in experimental infections (Strongyloides ratti and Strongyloides venezuelensis) $(3,4)$. Usually, hosts become infected when free-living infective third stage larvae (L3sv) penetrate the skin and/or digestive mucosal surfaces. These larvae gain access to blood vessels and are dispersed to many organs, being passed through the lungs (3). During this migration L3sv moult to L4 stage and then the adult parasitic worms appear in the gut after a few days with reproduction commencing shortly thereafter, detected by the presence of eggs and/or larvae in the faeces. A key pathogenic clue of acute infection (and probably of hyper infection) by Strongyloides spp. is their dissemination through blood vessels until they reach target organs (mainly lung and gut). There are no direct data on the role of Strongyloides spp. infection on angiogenesis. However, both indirect evidence in experimental model (3), and human hyperinfection (demonstration of vascular anomalies by arteriography or endoscopy) $(5,6)$ suggest the involvement of angiogenic factors in the pathogenesis of this infection.

Angiogenesis is the process of new blood vessel formation from pre-existing ones, plays a key role in various 2 physiological and pathological conditions, including 
embryonic development, wound repair, tumour growth and inflammation (7). Angiogenesis is initiated by vasodilatation and an increased permeability being regulated by a delicate balance of pro and anti-angiogenic factors. Amongst angiogenic factors, vascular endothelial growth factor (VEGF)/vascular permeability factor and fibroblast growth factor-2 (FGF-2) are the best characterized positive regulators. In particular, VEGF has distinct specificity for vascular endothelial cells (8). The biological actions of VEGF include stimulation of endothelial cell proliferation, migration, differentiation, tube formation, vascular permeability and maintenance of vascular integrity (9). FGF2 is less specific for endothelial cell proliferation, but is a potent angiogenic factor in vitro and in vivo (10). Moreover, many endogenous inhibitors of angiogenesis have been described, endostatin (C-terminal fragment of collagen XVIII) and angiostatin being the best characterized (11). Although the precise mechanism for the antiangiogenic effect of endostatin is not well known, this molecule can block endothelial cell proliferation, survival and migration through blocking VEGFR2 signalling and other mechanisms (12).

The aim of this study was to evaluate the role of angiogenic and angiostatic factors in the pathogenesis of experimental strongyloidiasis. We used two complimentary approaches: (i) an in vivo model of infection by $S$. venezuelensis in CD1 mice was used for the evaluation of the effect of endostatin on the parasitic infection and for the mechanisms involved in the reduction of parasite burden, (ii) an in vitro study of the antigens responsible for stimulation of angiogenic factors from alveolar macrophages and the mechanisms involved in their production.

\section{MATERIALS AND METHODS}

\section{Animals}

Male Wistar rats and female CD1 mice were purchased from Charles River Laboratories, Barcelona, Spain. All experiments of this work comply with current European Union law on animal experimentation. All infected and control animal strains were maintained under standard laboratory conditions in the animal experimentation facilities of the Salamanca University.

\section{Parasites and antigens}

Strongyloides venezuelensis filariform infective larvae (L3sv) and adult female were obtained from the strain of the Department of Parasitology of the University of Minas Geráis, Belo Horizonte, Brazil and their lifecycle was maintained by serial passages in male 4-week-old Wistar rats in Salamanca University. L3sv and adults were decontaminated according to Martins et al. (13). The larvae were suspended at a concentration of $3.0 \times 10^{5} / \mathrm{mL}$ in PBS with protease inhibitors with a final concentration of $5 \mathrm{~mm}$ ethylenediaminetetraacetic acid, $2 \mathrm{~mm}$ phenylmethylsulphonyl fluoride, $1 \mu \mathrm{M}$ pepstatin, $4 \mu \mathrm{M}$ aproptinin and $10 \mu \mathrm{M}$ chymostatin. PBS-soluble extract antigen (L3-PBS) was obtained according to Conway et al. (14). Excretory secretory antigens of larvae (L3-ES) were prepared in accordance with Northern and Grove (15). Every day cultures were observed and when motility was less than $80 \%$ they were discarded. Female adult worms were suspended in PBS with protease inhibitors as above. Alkaline extract of adult $S$. venezuelensis (F-ALK) was prepared according to Machado et al. (16). Female excretory secretory antigens (F-ES) were prepared in accordance with Brindley et al. (17). Cultures were observed day to day to monitor motility and every 2 days supernatants were collected as above.

All antigens were aliquoted and stored at $-80^{\circ} \mathrm{C}$. Protein concentration was determined using the Micro $\mathrm{BCA}^{\mathrm{TM}}$ Protein Assay Kit (Pierce, Rockford, IL, USA) and samples were run in a $15 \%$ sodium dodecyl sulphatepolyacrylamide gel electrophoresis to assess the antigen.

\section{Evaluation of the effect of endostatin on $S$. venezuelensis infection in murine experimental model}

In the first experiment, we used three groups of 6-weekold CD1 mice weighing 16-25 g, as follows: Group A, uninfected group; Group B, mice infected with 3000 L3 of $S$. venezuelensis per animal; Group C, mice infected with $3000 \mathrm{~L} 3$ and treated with $2.5 \mathrm{mg} / \mathrm{kg}$ of endostatin (Sigma Chemical Co, St Louis, MO) at days 0 and 2. On the third day of the experiment, mice were killed and the lungs were harvested. The lungs were then sliced and larvae were collected and counted. At 0 and 3 days of the experiment, we collected blood samples in EDTA anticoagulant under isoflurane anaesthesia (Isoba vet; Schering-Plough) for blood $\mathbf{3}$ cell counts with a hemocytometer Hemavet 950 (Drew Scientific Group). Also, lungs, liver and gut were recovered $\mathbf{4}$ for RNA extraction.

In the second experiment, we used three groups of 6week-old CD1 mice weighing 16-25 g, as follows: Group A, uninfected group; Group B, mice infected with 3000 L3 of $S$ venezuelensis per animal; Group C, mice treated with $2.5 \mathrm{mg} / \mathrm{kg}$ of endostatin at days $1,3,5$ and 7 of the experiment and infected with $3000 \mathrm{~L} 3$ at day 2. All the animals were killed at day 14 of the experiment. The infection was monitored daily from day 6 of the experiment, counting eggs per gram of faeces. Animals were placed individually on clean, moist absorbent paper and allowed to defecate. 
Eggs were counted using the Cornell-McMaster quantitative method. Faeces were weighed and broken up in a known volume of a $10 \%$ formalin solution in a $1.5 \mathrm{~mL}$ vial. The parasitological analysis was performed twice. Blood samples were obtained on days 1, 4, 7, 12 and 14 of the experiment to count blood cells in a Hemavet 950

5 hemocytometer as above. The animals were then killed and adult worms in intestine were recovered. Lungs, liver and small intestine were recovered for RNA collection.

\section{Detection of VEGF and FGF2 in mice infected with $S$. venezuelensis by RT-PCR}

Total RNA was extracted from the snap-frozen tissue using an RNeasy Mini Kit (Qiagen GmbH, Hilden Germany). A total of $1 \mu \mathrm{g}$ of RNA was used as template for

6 the first-strand DNA synthesis (Roche). Primers specific for rat VEGF were used in accordance with Yang et al. (18). Primer sequence for VEGF was: sense, 5'CTGCTCTCTTGGGTGCACTGG-3' and anti-sense, 5'CACCGCCTTGGCTTGTCACAT- $3^{\prime}$, generate three bands of 601,540 and $408 \mathrm{bp}$, corresponding to VEGF isoforms of 188,164 and 120 amino acids. Primers specific for glyceraldehyde 3-phosphate dehydrogenase (GAPDH) were: sense, 5'-GGTCGGTGTGAACGGATTTG-3' and GAPDH anti-sense, 5'-GTGAGCCCCAGCCTTCTCCAT-3' generating 452 bp PCR product. PCR reactions were carried out through reverse transcription incubation at $94^{\circ} \mathrm{C}$ for $5 \mathrm{~min}, 35$ cycles of $94^{\circ} \mathrm{C}$ for $1 \mathrm{~min}, 55^{\circ} \mathrm{C}$ for $1 \mathrm{~min}, 72^{\circ} \mathrm{C}$ for $1 \mathrm{~min}$ and a single cycle at $72^{\circ} \mathrm{C}$ for $7 \mathrm{~min}$. PCR products were analysed by electrophoresis in $2 \%$ agarose gel stained with ethidium bromide. Primers specific for detection of FGF2 were used in accordance with Jyo-Oshiro et al. (19). Primer sequence for FGF2 was: sense, 5'-GCCGGCAGCATCACTTCGCT-3' and anti-sense, 5'-CTGTCCAGGCCCCGTTTTGG-3'. PCR reactions were carried out through reverse transcription incubation at $94^{\circ} \mathrm{C}$ for $2 \mathrm{~min}, 50$ cycles of $94^{\circ} \mathrm{C}$ for $30 \mathrm{~s}$, $60^{\circ} \mathrm{C}$ for $30 \mathrm{~s}, 72^{\circ} \mathrm{C}$ for $1 \mathrm{~min}$ and a single cycle at $72^{\circ} \mathrm{C}$ for $5 \mathrm{~min}$. PCR products were analysed by electrophoresis in $1.5 \%$ agarose gel stained with ethidium bromide with GADPH as internal control.

\section{Evaluation of the effect of endostatin on L3 larvae of $S$. venezuelensis}

A range of endostatin concentrations between $0 \cdot 1$ and $50 \mu \mathrm{g} / \mathrm{mL}$ was applied in phosphate buffered saline (PBS

$7 \mathrm{pH}$ 7.2). Ivermectin (Sigma) and was used as positive control at $10 \mu \mathrm{g} / \mathrm{mL}$ final concentrations. We observed the effect of endostatin on the parasite in vitro 300 L3 larvae of $S$. venezuelensis in each well. The experiment was per- formed by triplicate after incubation at $37^{\circ} \mathrm{C}$ in $5 \% \mathrm{CO} 2$. The viability of the L3 was calculated by the detection of motility by the light microscope. We observed the larval motility between $1 \mathrm{~h}$ until 6 days.

\section{Isolation and culture of alveolar macrophages}

Alveolar macrophages were obtained from male Wistar rats of $250-300 \mathrm{~g}$ by bronchoalveolar lavage as previously described (20). The latter were washed twice with PBS $(\mathrm{pH} 7 \cdot 4)$ and the cells were re-suspended at a concentration of $1 \times 10^{6} / \mathrm{mL}$. Alveolar macrophages were cultured as previously described (20). Briefly, cells were re-suspended in Dulbecco's Modified Eagle Medium supplemented with $10 \% \gamma$-irradiated foetal bovine serum, $2 \mathrm{~mm}$ glutamine, $100 \mathrm{U} / \mathrm{mL}$ penicillin and $100 \mathrm{mg} / \mathrm{mL}$ streptomycin (Sigma Chemical Co, St Louis, MO, USA), and maintained at $37^{\circ} \mathrm{C}$ in $5 \% \mathrm{CO} 2$. Macrophages in culture were incubated alone (negative control, Ø), with lipopolysaccharide $10 \mu \mathrm{g} / \mathrm{mL}$ (LPS; Sigma; positive control) and/or with several concentrations, ranging from $0 \cdot 1$ to $50 \mu \mathrm{g}$ protein $/ \mathrm{mL}$, of different parasite antigens. The LPS dose used in our studies was chosen as optimal based on previous investigations (21). After $18 \mathrm{~h}$ at $37^{\circ} \mathrm{C}$ in $5 \% \mathrm{CO} 2$, culture supernatants were collected, centrifuged at $500 \mathrm{~g}$ for $10 \mathrm{~min}$ and stored at $-80^{\circ} \mathrm{C}$ until analysis. Remaining cells were subjected to the MTT via- $\mathbf{8}$ bility assay as described earlier (20), viability being higher than $87 \cdot 5 \%$ in all cases. Following the viability assay, alveolar macrophages were collected and stored at $-80^{\circ} \mathrm{C}$ for further analysis.

\section{Detection of VEGF and FGF2 in alveolar macrophages by RT-PCR}

Total RNA was extracted from alveolar macrophages using an RNeasy Mini Kit (Qiagen Inc.). A total of $1 \mu \mathrm{g}$ RNA was used as template for the first-strand DNA synthesis (Roche). Primers specific for VEGF, FGF2 and GAPDH were used as above.

\section{Effect of inhibitors of Nitric Oxide on VEGF and FGF2 expression}

To determine the relationship between nitric oxide and VEGF and FGF2 on macrophage cells stimulated by $S$. venezuelensis antigen we used an inhibitor of all nitric oxide synthase (iNOS) isoforms - nitro-L-arginine methyl ester (L-NAME; Affinity) and a specific inhibitor of iNOS 9 - L-canavanine (Sigma). Both inhibitors were used at a final concentration of $100 \mathrm{~mm}$ as previously described by Andrade et al. (20). 
Polymyxin B, a specific inhibitor of LPS, was used to assess possible LPS contamination or LPS-like activity in the different parasite antigens used during our study (22). Briefly, alveolar macrophages were incubated with $80 \mu \mathrm{g} / \mathrm{mL}$ of polymyxin B plus LPS $(10 \mu \mathrm{g} / \mathrm{mL})$ and $50 \mu \mathrm{g} / \mathrm{mL}$ antigens parasite. S. venezuelensis antigens were used at different concentrations $(0 \cdot 1-50 \mu \mathrm{g} / \mathrm{mL})$ on alveolar macrophages.

\section{Statistical analysis}

The results of the faecal egg counts, larvae and adult females were reported as arithmetic mean and standard deviation. Differences in groups were performed by ANOVA. When global differences were detected, a post-ANOva test using the Fisher LSD analysis was applied. Differences between means were considered statistically significant at $P<0.05$. All statistical analyses were performed using Statworks and Statview 4.5 software packages for a 10 Macintosh computer.

\section{RESULTS}

\section{Evaluation of the effects of endostatin on $S$. venezuelensis infection in a murine experimental model}

We evaluated the effect of endostatin on collection of larvae in mice infected with $3000 \mathrm{~L} 3$ of $S$. venezuelensis and mice treated with endostatin in lung. We individually observed the data of collection of larvae in lung, as well as its mean and standard error of the mean (Figure 1a). The mean number of L3 S. venezuelensis recovered at 2 days post-infection was $196 \pm 22$ in the group of infected mice, compared with $69 \pm 15$ in the group of mice treated with endostatin. The differences were statistically significant $P<0.05$.

In addition, we evaluated the effect of endostatin on collection of females in intestine. We individually observed the data of collection of females in intestine, as well as mean and standard error of the mean (Figure $1 \mathrm{~b}$ ). The mean number of female parasites recovered
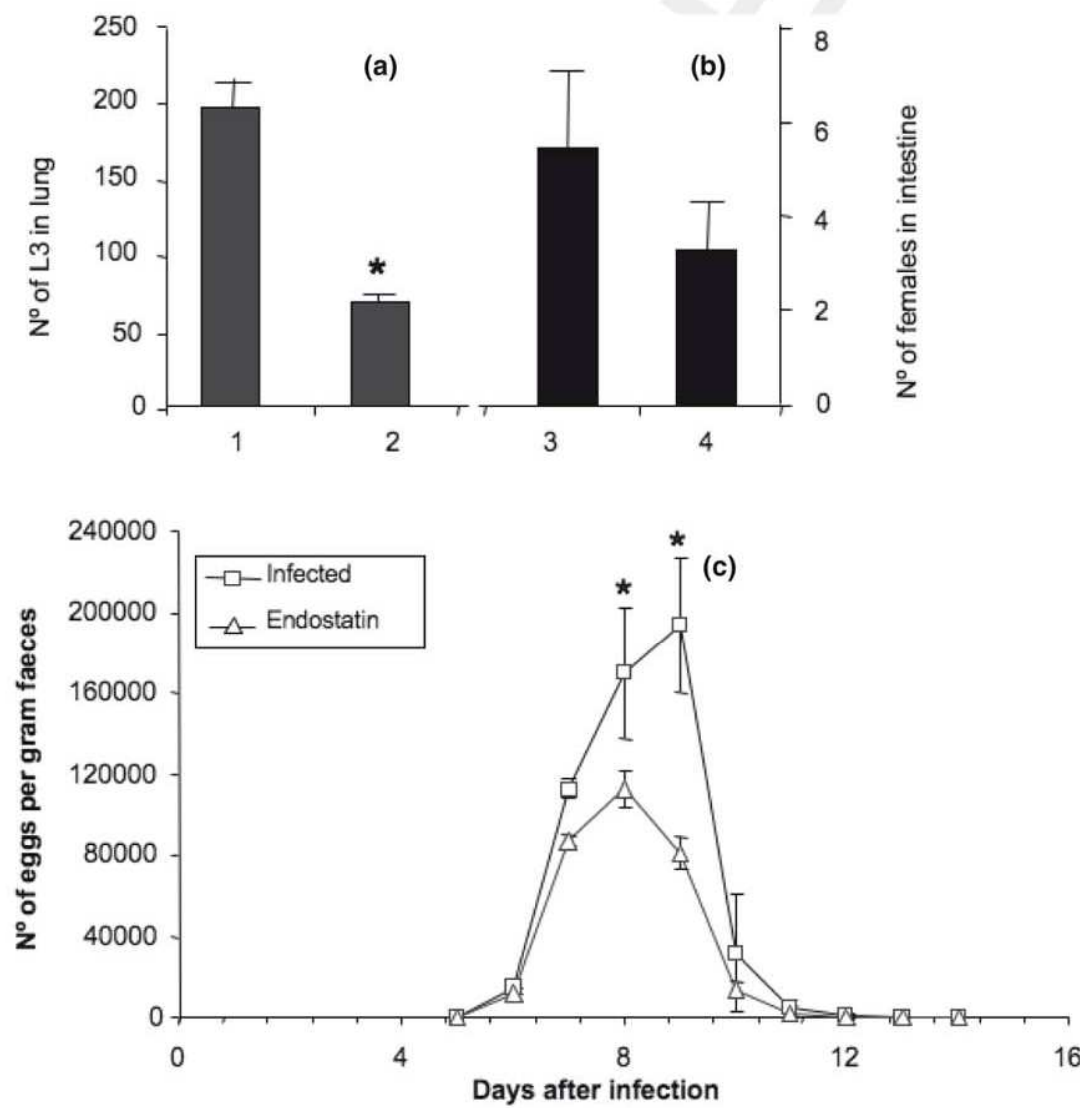

Figure 1 (a) Numbers of L3 of Strongyloides venezuelensis recovered from lung at 2 days post-infection: mean \pm standard error in infected mice group (1). Mean \pm standard error in mice treated with endostatin $(2.5 \mathrm{mg} / \mathrm{kg})(2) ;{ }^{*} P<0.05$. (b) Numbers of females of $S$. venezuelensis recovered from intestine at 14 days post-infection: Mean \pm Standard error in group of infected mice (3): mean \pm standard error in mice treated with endostatin $(2.5 \mathrm{mg} / \mathrm{kg})(4) ;{ }^{*} P<0 \cdot 05$. (c) Number of eggs per gram of faeces counted from 5 to 14 days post-infection in infected mice and infected mice treated with endostatin. ${ }^{*} P<0 \cdot 05$. 

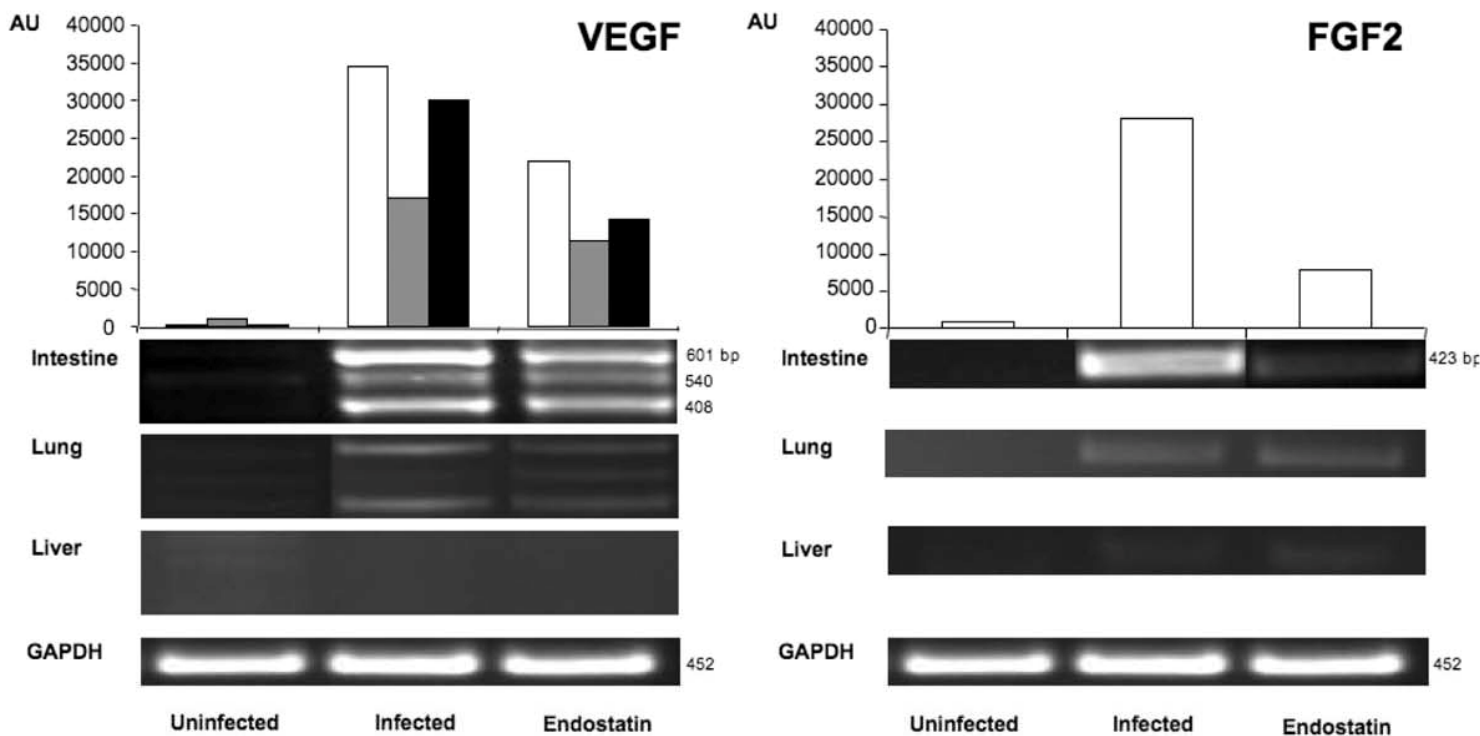

Figure 3 RT-PCR for VEGF and FGF2 detection from intestine, lung and liver at 14 days post-infection in three experimental groups: Uninfected mice, mice infected with $3000 \mathrm{~L} 3$ of Strongyloides venezuelensis and mice treated with $2.5 \mathrm{mg} / \mathrm{kg}$ endostatin and infected as above. VEGF expressed in intestine, lung and not expressed in liver. FGF2 expressed in intestine and less than in lung but not expressed in liver. AU arbitrary units calculated by densitometry of corresponding amplicons, 601 (white bars), 540 (grey bars) and 408 bp (black bars) for VEGF, a band with 423 bp (white bars) for FGF2. GAPDH expression was used as internal control

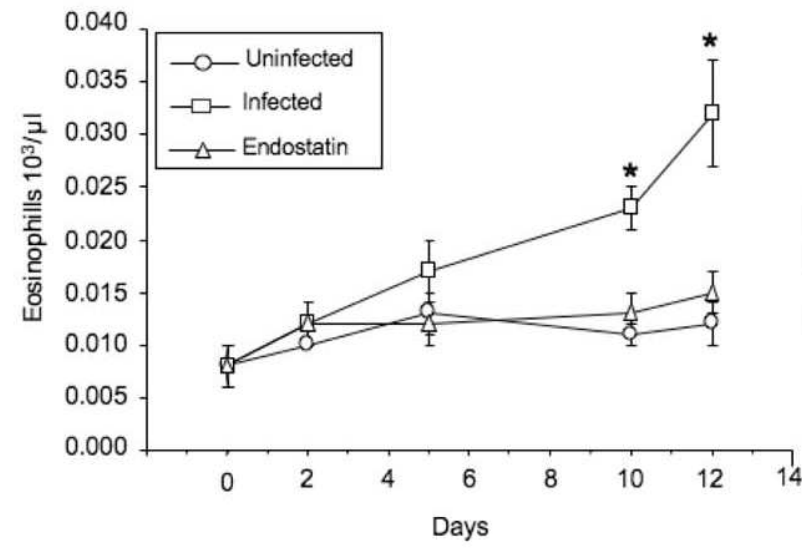

Figure 4 Numbers of total eosinophils were enumerated and identified through Hemavet. Data are expressed as mean's of the cell numbers from uninfected animals $(n=6 /$ day), infected mice with $3000 \mathrm{~L} 3$ of Strongyloides venezuelensis ( $n=6 /$ day), infected mice treated with $2.5 \mathrm{mg} / \mathrm{kg}$ of endostatin $(n=6 /$ day). ${ }^{*} P<0 \cdot 05$.

mectin after $48 \mathrm{~h}$ demonstrated $3 \pm 1 \%$ of mobility. Moreover, mobility at 3 days of experiment reached to zero. On the other hand, untreated larvae presented mobility between $88 \pm 2 \cdot 3$ and $97 \pm 0.6$ and larvae treated with concentrations of $0 \cdot 1$ to $50 \mu \mathrm{g} / \mathrm{mL}$ endostatin demonstrated mobility between $81 \pm 3 \cdot 2$ and $96 \pm 1$. This experiment demonstrated that endostatin has not direct effect on L3 larvae of $S$. venezuelensis.
Evaluation of the antigens of $S$. venezuelensis in the stimulation of angiogenic factors (VEGF and FGF2) by alveolar macrophages

We studied the effects of different concentrations of different antigens of $S$. venezuelensis $(0 \cdot 1-50 \mu \mathrm{g} / \mathrm{mL})$ on the expression of VEGF and FGF2 in alveolar macrophages (Figure 6). The results indicate that macrophages stimulated with larvae PBS-soluble extract (L3-PBS) from $1 \mu \mathrm{g} / \mathrm{mL}$ induced VEGF (601 bp isoforms) and FGF2 mRNA expression in a dependent dose when compared with other antigens of $S$. venezuelensis. Antigens from excretory secretory larvae (L3-ES), somatic and excretory secretory female (F-ALK and F-ES) antigens of S. venezuelensis were not able to cause the expression of either VEGF or FGF2.

Evaluation of the mechanisms involved in the stimulation of angiogenic factors (VEGF and FGF2) by alveolar macrophages

VEGF production of macrophages incubated with L3-PBS antigen from $S$. venezuelensis larvae and the nitric oxide specific inhibitors (L-NAME or L-canavanine) was completely abolished with differences between cells incubated with the antigens alone and the combination of the inhibitors plus the antigens (Figure 7). Similarly, results were obtained for the expression of FGF2 when cells incubated 


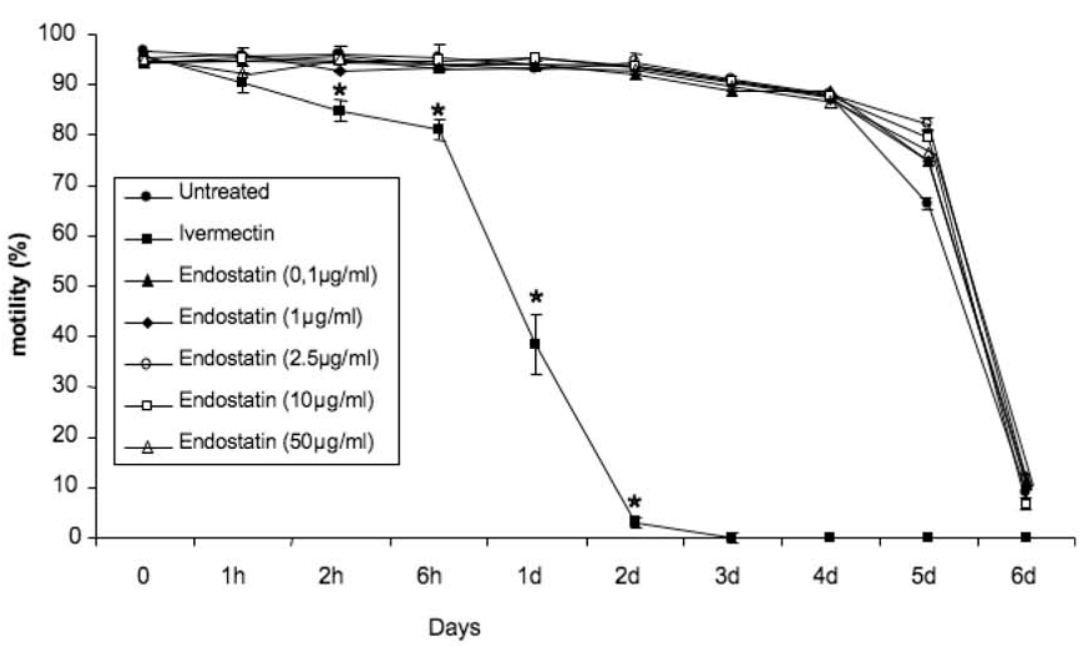

Figure 5 Effect of endostatin on culture of L3 Strongyloides venezuelensis, Untreated L3 of S. venezuelensis in PBS and L3 treated with ivermectin $(10 \mu \mathrm{g} / \mathrm{mL})$ were used as controls. Endostatin was used at different concentrations $(0 \cdot 1-50 \mu \mathrm{g} / \mathrm{mL})$. Cultures were maintained during 6 days and were performed by triplicate.
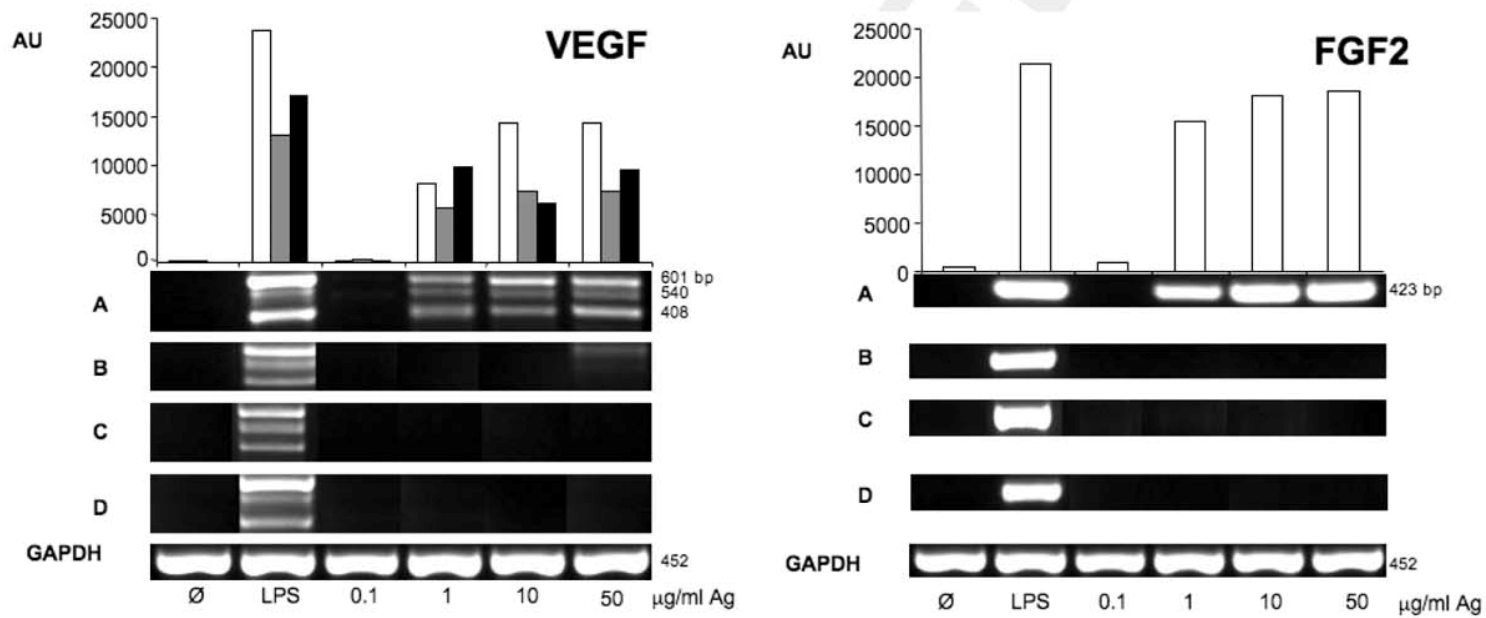

Figure 6 Effect of Strongyloides venezuelensis antigens on expression of VEGF and FGF2 in alveolar macrophages, (a) mRNA expression in rat alveolar macrophages by PBS-soluble extract from larvae 3 of Strongyloides venezuelensis (L3-PBS), (b) excretory secretory antigens of L3 of $S$ venezuelensis (L3-ES), (c) Alkaline extract of female (F-ALK) and (d) female worm excretory secretory antigens (F-ES). GAPDH mRNA expression levels from rat macrophages detected by RT-PCR are used as internal positive control. Nonstimulated macrophages, negative control (Ø), LPS stimulated macrophages, positive control (LPS) and different concentrations of $S$ venezuelensis antigens, $0 \cdot 1-$ $50 \mu \mathrm{g} / \mathrm{mL}$ (A-D) AU, arbitrary units calculated by densitometry of corresponding amplicons. 601 bp VEGF band (white bars), 540 bp VEGF band (grey bars) and 408 bp VEGF band (black bars). 423 bp FGF2 band (white bars).

with L3-PBS antigen and the nitric oxide specific inhibitors. In addition, a similar effect was observed with cells incubated with LPS and cells incubated with LPS plus nitric oxide inhibitors.

\section{DISCUSSION}

Strongyloidiasis is one of the major nematode infections of humans with cosmopolitan distribution in tropical and subtropical regions (23). It is estimated that some 100
200 million individuals are infected worldwide with Strongyloides spp., however, these infections can be difficult to detect, so these may be underestimates. Strongyloides infection in immunocompromized individuals, particularly following the administration of steroids, can result in disseminated strongyloidiasis (2). Some authors proposed that $S$. ratti and $S$. venezuelensis are suitable parasite models for the study of $S$. stercoralis (24).Our previous work has shown the production of nitric oxide by alveolar macrophages stimulated with larvae antigen of $S$. 


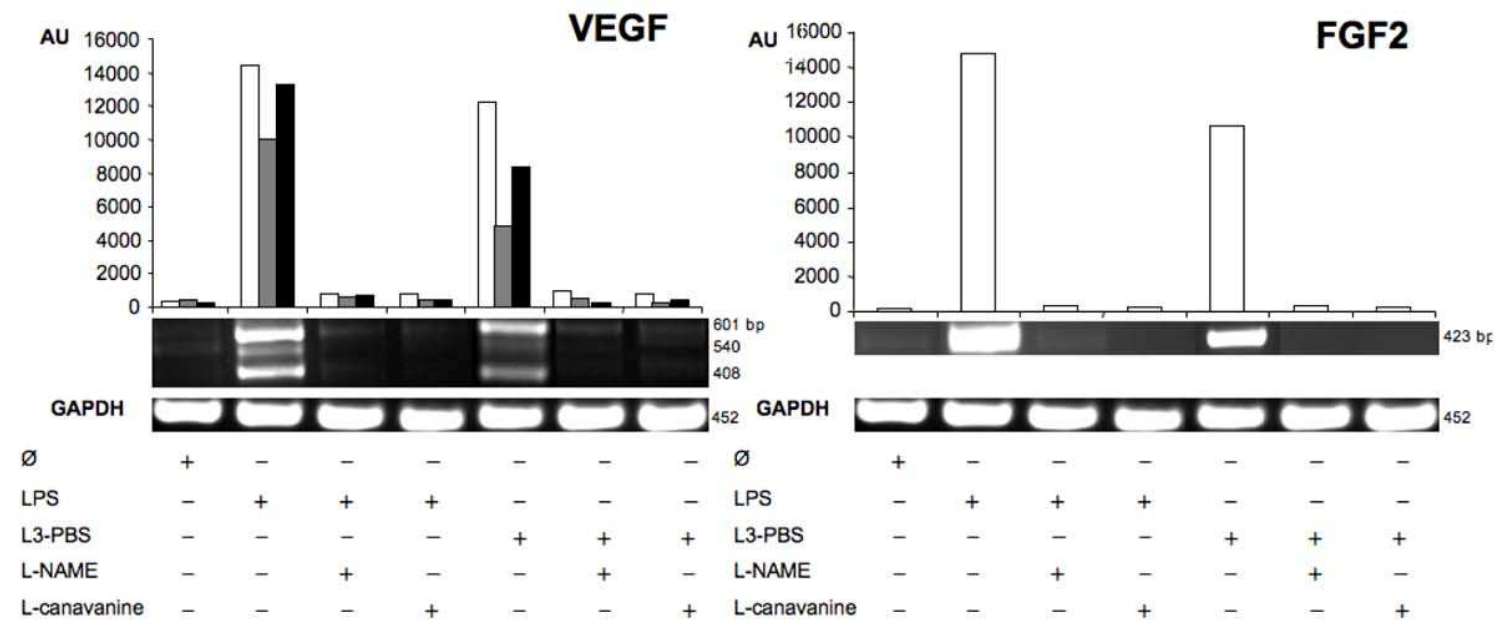

Figure 7 Effects of specific inhibitor of inducible nitric oxide synthase (iNOS) with L3-PBS antigen of Strongyloides venezuelensis on mac- 18 rophage VEGF and FGF2 production. GAPDH mRNA expression levels from rat macrophages detected by RT-PCR are used as internal positive control. Nonstimulated (Ø), stimulated (LPS), LPS + L-NAME, LPS + L-canavanine, L3-PBS $50 \mu \mathrm{g} / \mathrm{mL}$ stimulated, L3-PBS $50 \mu \mathrm{g} / \mathrm{mL}+\mathrm{L}-\mathrm{NAME}$, L3-PBS $50 \mu \mathrm{g} / \mathrm{mL}+\mathrm{L}$-Canavanine AU, arbitrary units calculated by densitometry of corresponding amplicons. 601 bp VEGF band (white bars), 540 bp VEGF band (grey bars) and 408 bp VEGF band (black bars). 423 bp FGF2 band (white bars).

venezuelensis (L3-PBS), demonstrating the participation of this inflammatory mediator in the experimental strongyloidiasis (unpublished data). Nevertheless, more studies are needed to determine the role of other inflammatory mediators and the relationship with nitric oxide in the strongyloidiasis.

Angiogenesis is a complex multi-step process that leads to neovascularization generated from pre-existing blood vessels. It is associated with inflammation, wound healing, tumour growth and metastasis. The generation of new blood vessels is regulated by proangiogenic and antiangiogenic molecules (25). VEGF and FGF2 are major mediators of angiogenesis in the development and progression of many diseases. Few studies exist about the relation between angiogenesis factors and helminthoses. A positive correlation was observed between plasma VEGF and the stage of hydrocoele in men infected with the filarial nematode Wuchereria bancrofti (26). Also, VEGF was found to be protective against cerebral malaria associated mortality (27). In the present work we evaluated the role of angiogenesis factors in the experimental strongyloidiasis: the modulation of the infection using a specific inhibitor of angiogenesis (endostatin), the induction of VEGF and FGF2 in alveolar macrophages stimulated with different antigens derived from different phases of the biological cycle of $S$. venezuelensis and the probable relationship between these factors and the production of nitric oxide.

Endostatin is a $20-\mathrm{kDa}$ C-terminal fragment of collagen XVIII that, when added exogenously, inhibits angiogenesis (28). Our work demonstrates that the angiogenesis factors have an important function in the primary infection by $S$. venezuelensis. The endostatin diminishes both the number of larvae in lung and the number of eggs in the faeces. Is this because of direct effects of the parasite or is it indirectly via effects of the host? For answer this question, we performed in vitro studies on the effect of endostatin on parasite mobility. We demonstrated that endostatin has not direct effects on L3 larvae of S. venezuelensis. Then, indirect effects on the host could be attributed to the endostatin treatment. This can be associated to two complementary mechanisms. First, endostatin directly decreases the expression of the mean angiogenic factors. In fact, we have shown that mice treated with endostatin and infected with Strongyloides spp., have a reduced expression of VEGF and FGF2 both in lung and intestine. Secondly, some authors observed that eosinophil potentially participates in angiogenesis by inducing VEGF production (29). Moreover, VEGF has been associated with blood-brain barrier disruption in patients with eosinophilic meningitis caused by Angyostrongylus cantonensis (30). When compared with the infected group our data indicate that mice infected with $S$. venezuelensis and treated with endostatin have a significant reduction of blood eosinophil counts.

Macrophages are known to produce several potent angiogenic factors including VEGF, placenta growth factor, basic FGF2, transforming growth factor- $\beta$ and IL-8 and a lot of pro-inflammatory cytokines such as IL-1 $\beta$, IL-6, TNF- $\alpha$ and granulocyte monocyte-colony stimulating factor (31). Studies performed by our group have demonstrated the induction of VEGF and FGF2 in alveolar macrophages stimulated with larvae antigens of $T$. spiralis 11 (32). In the present paper, we studied the effect of somatic 
and excretory/secretory antigens of larvae and females of S. venezuelensis on the production of VEGF and FGF2 in alveolar macrophages. Only the somatic antigen of larvae 3 of $S$ venezuelensis stimulates the production of angiogenesis factors (VEGF and FGF2). In addition, we investigated whether the effect exerted by these antigens in the modulation of the angiogenesis factors was direct or through other inflammatory mediators, such as nitric oxide. iNOS is known to regulate VEGF expression, and thereby angiogenesis (33-35). As alveolar macrophages release nitric oxide in response to helminthic antigens (21), may be inhibition of iNOS could be decreased VEGF production. We confirmed the relationship between the production of nitric oxide and the angiogenesis factors by using inhibitors of the ONSi (L-NAME and L-canavanine), which inhibited the expression of angiogenesis factors.

In summary, this study demonstrated that angiogenesis factors play a role in the primary infection by $S$. venezuelensis as the inhibition by endostatin produced a decrease in the number of larvae and females. Direct mechanisms with diminution of angiogenesis factors and indirect mechanisms with decrease of the number of eosinophils could be related to the protection from the parasitic infection. Angiogenic factors are induced by somatic antigens of third stage larvae of $S$. venezuelensis. A positive relationship between angiogenesis factors and nitric oxide has been observed using nitric oxide synthase inhibitors.

\section{ACKNOWLEDGEMENTS}

This work was supported by the projects of Junta Castilla y León SA116A08. Shariati F fellowship, acknowledges financial support from Ministry of science of IR Iran.

\section{REFERENCES}

1 Siddiqui AA \& Berk SL. Diagnosis of Strongyloides stercoralis infection. Clin Infect Dis 2001; 33: 1040-1047.

2 Vadlamudi RS, Chi DS \& Krishnaswamy G. Intestinal strongyloidiasis and hyperinfection syndrome. Clin Mol Allergy 2006; 4: 8 .

3 McHugh TD, Jenkins T, Greenwood R \& McLaren DJ. The migration and attrition of Strongyloides ratti in naive and sensitized rats. $J$ Helminthol 1994; 68: 143-8.

4 Tsuji N, Ohta M \& Fujisaki K. Expression of a 70-kDa heatshock-related protein during transformation from free-living infective larvae to the parasitic stage in Strongyloides venezuelensis. Parasitol Res 1997; 83: 99-102.

5 Csermely L, Jaafar H, Kristensen J, et al. Strongyloides hyperinfection causing life-threatening gastrointestinal bleeding. World J Gastroenterol 2006; 12: 6401-4.

6 Thompson BF, Fry LC, Wells CD, et al. The spectrum of GI strongyloidiasis: an endoscopic-pathologic study. Gastrointest Endosc 2004; 59: 906-10.
7 Carmeliet P \& Jain RK. Angiogenesis in cancer and other diseases. Nature 2000; 407: 249-57.

8 Shibuya M. Structure and function of VEGF/VEGF-receptor system involved in angiogenesis. Cell Struct Funct 2001; 26: 25-35.

9 Ferrara N \& Davis-Smyth T. The biology of vascular endothelial growth factor. Endocr Rev 1997; 18: 4-25.

10 Bikfalvi A, Klein S, Pintucci G \& Rifkin DB. Biological roles of fibroblast growth factor-2. Endocr Rev 1997; 18: 2645.

11 Bouïs D, Kusumanto Y, Meijer C, Mulder NH \& Hospers GA. A review on pro- and anti-angiogenic factors as targets of clinical intervention. Pharmacol Res 2006; 53: 89-103.

12 Benezra R \& Rafii S. Endostatin's endpoints-deciphering the endostatin antiangiogenic pathway. Cancer Cell 2004; 5: 205-6.

13 Martins WA, Melo AL, Nicoli JR, et al. A method decontaminating Strongyloides venezuelensis larvae for the study of strongyloidiasis in germ-free and conventional mice. $J$ Med Microbiol 2000; 49: 387-90.

14 Conway DJ, Lindo JF, Robinson RD, Bundy DA \& Bianco AE. Strongyloides stercoralis: characterization of immunodiagnostic larval antigens. Exp Parasitol 1994; 79: 99-105.

15 Northern C \& Grove DI. Strongyloides stercoralis: antigenic analysis of infective larvae and adult worms. Int J Parasitol 1990; 20: 381-7.

16 Machado ER, Ueta MT, Gonçalves-Pires MR, Alves de Oliveira JB, Faccioli LH \& Costa-Cruz JM. Strongyloides venezuelensis alkaline extract for the diagnosis of human strongyloidiasis by enzyme-linked immunosorbent assay. Mem Inst Oswaldo Cruz 2003; 98: 849-51.

17 Brindley PJ, Gam AA, Pearce EJ, Poindexter RW \& Neva FA. Antigens from the surface and excretions/secretions of the filariform larva of Strongyloides stercoralis. Mol Biochem Parasitol 1988; 28: 171-80.

18 Yang ZF, Ho DW, Chu AC, Wang YQ \& Fan ST. Linking inflammation to acute rejection in small-for-size liver allografts: the potential role of early macrophage activation. $\mathrm{Am} \mathrm{J}$ Transplant 2004; 4: 196-209.

19 Jyo-Oshiro Y, Sasaki T, Kawakami Y, et al. Expression of the fibroblast growth factor receptor 1-4 genes in glomeruli in anti-Thy1.1 mesangial proliferative glomerulonephritis. Virchows Arch 1999; 435: 501-8.

20 Andrade MA, Siles-Lucas M, Espinoza EY, Pérez-Arellano JL, Gottstein B \& Muro A. Echinococcus multilocularis laminated layer components and the E14t 14-3-3 recombinant protein decrease NO production by activated rat macrophages in vitro. Nitric Oxide Biol Chem 2004; 10: 150-155.

21 Espinoza E, Muro A, Martin MM, Casanueva P \& Pérez-Arellano JL. Toxocara canis antigens stimulate the production of nitric oxide and prostaglandin E2 by rat alveolar macrophages. Parasite Immunol 2002; 24: 311-9.

22 Taylor MJ, Cross HF, Ford L, Makunde WH \& Bilo K. Wolbachia bacteria in filarial immunity and disease. Parasite Immunol 2001; 23: 401-409.

23 Viney ME \& Lok JB. Strongyloides spp.. WormBook 2007; 23: $1-15$.

24 Baek BK, Whang IS, Islam MK, Kim BS \& Kakoma I. Persistent infection with Strongyloides venezuelensis in the Mongolian gerbil (Meriones unguiculatus). Korean J Parasitol 2002; 4: $181-186$. 
25 Ferreira V, Molina MC, Schwaeble W, Lemus D \& Ferriera A Does Trypanosoma cruzi calreticulin modulate the complement system and angiogenesis? J Parasitol 2005; 21: 4.

26 Debrah AY, Mand S, Toliat MR, et al. Plasma vascular endothelial growth factor-A (VEGF-A) and VEGF-A gene polymorphism are associated with hydrocele development in lymphatic filariasis. Am J Trop Med Hyg 2007; 77: 4.

27 Jain V, Armah HB, Tongren JE, et al. Plasma IP-10, apoptotic and angiogenic factors associated with fatal cerebral malaria in India. Malaria $J$ 2008; 7: 83-98.

28 Abdollahi A, Hlatky L \& Huber PE. Endostatin: the logic of antiangiogenic therapy. Drug Resist 2005; 8: 59-74.

29 Puxeddu N, Berkman AH, Nissim Ben Efraim DE, et al. The role of eosinophil major basic protein in angiogenesis. Allergy 2008; 64: 368-74.

30 Tsai HC, Liu YC, Lee SS, Chen ER \& Yen CM. Vascular endothelial growth factor is associated with blood brain barrier dysfunction in eosinophilic meningitis caused by Angiostrongylus cantonensis infection. Am J Trop Med Hyg 2007; 76: 592 95.

31 Wang C, Duan H \& He L. Inhibitory effect of atractylenolide I on angiogenesis in chronic inflammation in vivo and in vitro. Eur J Pharmacol 2009; 612: 143-52.
32 Shariati F, Pérez-Arellano JL, López-Abán J, Arefi M, Martínez-Fernández AR \& Muro A. Trichinella: differential expression of angiogenic factors in macrophages stimulated with antigens from encapsulated and non-encapsulated species. Exp Parasitol 2009; 123: 347-353.

33 Chin K, Kurshima Y, Ogura T, Tajiri H, Yoshida S \& Esumi $\mathrm{H}$. Induction of vascular endothelial growth factor by nitric oxide in human glioblastoma and hepatocellular carcinoma cells. Oncogene 1997; 15: 437-42.

$34 \mathrm{He} \mathrm{T}$, Ai M, Zhao XH \& Xing YQ. Inducible nitric oxide synthase mediates hypoxia-induced hypoxia-inducible factor-1 alpha activation and vascular endothelial growth factor expression in oxygen-induced retinopathy. Pathobiology 2007; 74: $336-43$.

35 Singh RP \& Agarwal R. Inducible nitric oxide synthase-vascular endothelial growth factor axis: a potential target to inhibit tumor angiogenesis by dietary agents. Curr Cancer Drug Targets 2007; 7: 475-83. 


\subsection{Article 3.}

Angiogenic Factors expression on schistosomiasis: human and experimental infections.

Fariborz Shariati, José Luis Pérez-Arellano, Cristina Carranza, Julio López-Abán, Belén Vicente, Maryam Arefi, Antonio Muro.

PLOS Neglected Diseases (Submitted, 20-January-2010) 
Title: Angiogenic Factors Expression on Schistosomiasis: Human and Experimental Infections.

Running head: Schistosomiasis and angiogenesis.

Authors: Fariborz Shariati ${ }^{1}$, Jose L. Pérez-Arellano ${ }^{2}$, Cristina Carranza ${ }^{2}$, Julio LópezAbán ${ }^{1}$, Belén Vicente ${ }^{1}$, Maryam Arefi ${ }^{3}$, Antonio Muro ${ }^{1 *}$

${ }^{1}$ Laboratorio de Inmunología y Parasitología Molecular, CIETUS, Facultad de Farmacia, Universidad de Salamanca. 37007-Salamanca, España.

${ }^{2}$ Departamento de Ciencias Médicas y Quirúrgicas. Facultad de Ciencias de la Salud, Universidad de Las Palmas de Gran Canaria. 35080-Las Palmas de Gran Canaria, España.

${ }^{3}$ Servicio de Hematología, Hospital Clínico Universitario de Salamanca, España.

* Corresponding author

\section{Abstract}

Background: Angiogenesis is the process of new blood vessel formation, has an important role in various processes, including cancer and inflammation. Schistosomiasis is a helminthoses that affects more than 200 million people in the world. Previous works have demonstrated that soluble antigens of Schistosoma mansoni induced angiogenesis by upregulation vascular endothelial growth factor (VEGF) in human endothelial cells. The objectives are: $(i)$ to study VEGF in sera of patients diagnosed of schistosomiasis and other helminthoses (ii) to evaluate the effect of endostatin (angiogenesis inhibitors) in mice infected with S. mansoni (iii) to detect VEGF and fibroblast growth factor (FGF2) expression in macrophages stimulated with $S$. mansoni antigens.

Methodology/Principal Findings: VGEF protein was detected in sera of healthy patients, patients diagnosed of schistosomiasis, filariasis and hookworms infections. Patient diagnosed with schistosomiasis only showed significant differences in VEGF level in 
compared with healthy patients. Uninfected group, mice infected with S. mansoni and mice infected and treated with endostatin were used. Parasitological, analytical data and IgG, IgG1 and IgG2a specific antibodies were analyzed. VEGF and FGF2 expression were detected by RT-PCR in liver and intestine. Mice treated with endostatin showed significant differences in eggs recoveries from liver and IgG2a antibodies detection in compared with infected mice group. Finally, the effects of the cercarial and adults $S$. mansoni antigens on the VEGF and FGF2 stimulation were evaluated. Macrophages were obtained by bronchoalveolar lavage (BAL) from Wistar rats. Cells were cultured at different concentrations of antigens $(0.1-50 \mu \mathrm{g} / \mathrm{ml})$, and their expression were determined by RTPCR. Cells stimulated with $50 \mu \mathrm{g} / \mathrm{ml}$ of cercarial $S$.mansoni antigens expressed VEGF and FGF2.

Conclusion/Significance: These finding may suggest the important role of angiogenic factors in the pathogenesis of schistosomiasis.

Competing interests: The authors have declared that no competing interests exist.

*E-mail: $\underline{\text { ama@usal.es }}$

\section{Summary:}

Schistosomiasis is one disease produced by helminths which affect many people in tropical areas. Except of acute phase (cercariae dermatitis and Katayama fever), granuloma formation is the principal mechanism involved in the pathogenesis of this disease. Experimental studies have demonstrated angiogenesis (blood vessels formation from preexisting vessels) in the initial phase of granuloma formation. In the present work, firstly the level of the main pro-angiogenic factors (vascular endothelial growth factor) were analyzed in sera from people diagnosed with schistosomiasis. We observed significantly high levels of this angiogenic factor in patients with schistosomiasis in compared with healthy people and patients diagnosed with other helminthic infections. In addition, we evaluated in experimental schistosomiasis murine model the effect of angiogenesis inhibition using antiangiogenic factors (endostatin). A lesion decrease was observed in mice pre-treated with endostatin and infected with Schistosoma mansoni. Finally, mechanisms of angiogenesis induction were studied and observed that cercariae antigens stimulated the angiogenic factors (vascular endothelial growth factor and fibroblastic growth factor-2) by host alveolar macrophages. 


\section{Introduction}

Schistosoma mansoni is one of the blood flukes there are to intravascular typical residence in the pelvic or mesenteric veins of the host. The female adult worms produce hundreds to thousands of eggs per day. Each ovum contains to ciliated miracidium larva, which secretes proteolytic enzymes that help the eggs to migrate into lumen of the bladder or the intestine [1]. Early pathological changes arise after mechanical occlusion of the microvasculature by the eggs causing acute vasculitis with endothelial damage and necrosis. Granuloma formation results from a delayed hypersensitivity response generated by the host against antigens secreted by the parasite eggs [2]. In initial phases the inflammatory response is intense with important neovascularization. Moreover, fibrosis was produced in later phases and it was responsible of the pathological disorders of this disease [3]. However, considerable variations in the magnitude of the disease have been described among different hosts and specifically among different mouse strains [4].

Angiogenesis, the formation of new endothelial vessels from pre-existing post-capillary venule, is a characteristic feature of inflammatory diseases, wound repair and cancer [5]. The angiogenic activity depends on the balance or imbalance between angiogenic and angiostatic mediators. Remodelling and degradation of the surrounding stroma is essential to start to an angiogenic phenotype. These stromal changes facilitate recruitment and activation of leucocytes, fibroblast and endothelial cells. While granulomas are traditionally considered to be avascular structures, schistosome granulomas should be seen as an inflammatory condition that initiates a variable degree of wound healing response in which angiogenesis and fibrosis are highly involved [6].

The aim of this work was to evaluate the role of angiogenic factors in the pathogenesis of schistosomiasis. Firstly, vascular endothelial growth factor (VEGF) detection in sera of patients diagnosed of schistosomiasis and other helminthic diseases were studied. Secondly, the effects of endostatin (angiogenesis inhibitor) in mice infected with Schistosoma mansoni were analyzed. Finally, VEGF and fibroblastic growth factor (FGF2) expression from alveolar macrophages stimulated with different S. mansoni antigens were analyzed.

\section{Methods}

\section{Human population}

The study group was formed by 53 patients from sub-Saharan areas with eosinophilia ( $\geq 450$ eosinophil/ $\mu 1)$. They had recently arrived in Canary Island of Spain. They have been 
living in Spain since 6 months ago and have been diagnosed only by one parasite as shown in Table 1. All patients were diagnosed by direct parasitological tests included: (i) Coprology in 3 stool samples for ova and parasites by using Kato-Katz and Ritchie techniques, (ii) Identification of Schistosoma haematobium by examination of urine for eggs with sedimentation, (iii) Knott's test for detection of microfilaremia in blood and (iv) Immune chromatographic test (ICT Filariasis, Binax, Portland and Maine) for the detection of Wuchereria bancrofti.

Healthy control group was formed by immigrants from the same geographic area as patients of the study group. We have done for all clinical examination, a systemic analytical study and also parasitological tests and direct serological examination. In all cases the control group, there were not detected eosinophilia and presence of parasite.

\section{Parasite and antigens}

BALB/C mice were maintained under standard conditions in an environment with controlled temperature and humidity with $12 \mathrm{~h}$ light/dark cycle and free access to water and food. Schistosoma mansoni cercariae were obtained from Biomphalaria glabrata snails previously infected with $S$. mansoni miracidia [7]. Mice were sacrificed on the 7 week postinfection (pi) and adult worms were recovered from the hepatic portal and mesenteric veins by perfusion technique[8].

Adult worm antigen (AWASm) and cercarial antigen (CSm) from S. mansoni were used accordance with Dunne et al[9]. Briefly, S. mansoni worms were recovered by portal perfusion buffer. Recovered worms were washed free of erythrocytes and then snap frozen in liquid nitrogen. Frozen worms were ground into a paste, allowed to thaw and then centrifuged at $10,000 \mathrm{~g}$ at $4^{\circ} \mathrm{C}$ for one hour. After that $1 \mathrm{mM} \mathrm{N}$-Tosyl-1 phenylalanine chloromethyl ketone and 1mM Phenyl-methylphonylfluride (Sigma Chemical Co, St Louise, MO) were added. The soluble material was centrifuged, filtered through a $0.22 \mu \mathrm{m}$ sterile filter and then stored at $-80^{\circ} \mathrm{C}$. Cercarial antigen $(\mathrm{CSm})$ was obtained from cercariae harvested within three hours of being shed from snail, snap frozen in liquid nitrogen and then processed identically to adult worm antigen. 


\section{VEGF detection in human samples}

The determination of VEGF was realised in serum from human samples by ELISA technique (Vascular Biotrak Endothelial Growth Factor [(h) VEGF] human ELISA System, GE Healthcare Buckinghamshire, UK) accordance with manufacture instructions.

\section{Mice experimental design}

Three groups of six-weeks-old CD1 mice weighing 16-25 g were used as follows: uninfected group, mice infected with $150 \mathrm{~S}$. mansoni cercariae per animal, mice infected with $150 \mathrm{~S}$. mansoni cercariae and treated with $2.5 \mathrm{mg} / \mathrm{kg}$ of endostatin (Sigma) at 36, 38, 40 and 42 days post-infection[10]. From these animals' sera and blood samples were taken weekly from week 0 to 7 after challenged.

Animals were sacrificed at week 7 post-infection (pi) and the following parasitological parameters were assessed: $(i)$ number of worms after liver perfusion, (ii) number of eggs per gram of liver, and (iii) number of eggs per gram of intestine, and (iv) number of granulomas on liver surface counted under a stereoscopic microscope. In addition, from all animals liver and intestine were harvested and adult worms were collected and counted. Blood samples were obtained and these samples were used for ELISA techniques and analyzed on hemocytometer Hemavet 950 (Drew Scientific Group).

ELISA technique was performed by detection of IgG, IgG1 and IgG2a in mice infected with Schistosoma mansoni and treated with endostatin. Briefly, 96-well polystyrene plates (Costar) were coated with $5 \mu \mathrm{g} / \mathrm{ml}$ of $S$. mansoni AWA antigen diluted in carbonate buffer $\mathrm{pH}$ 9.6. Serum were added at 1:100 dilutions and incubated for 1 hour at $37^{\circ} \mathrm{C}$. Horseradish peroxidase rabbit anti-mouse $\mathrm{IgG}, \mathrm{IgG1}$ and IgG2a (Sigma, St. Louis, MO.) at 1:1.000 dilution was added. After incubation for 1 hour at $37^{\circ} \mathrm{C}$, substrate solution (ortho-phenylene diamine plus $\mathrm{H}_{2} \mathrm{O}_{2}$ ) was added, and the reaction was stopped at 10 minutes with $3 \mathrm{NH}_{2} \mathrm{SO}_{4}$. Absorbances were measured at 492 on an Ear400FT ELISA reader (Lab Instruments). The results are expressed as means of the optical density from all the animals of each group plus the standard error.

\section{VEGF and FGF2 expression in mice infected with S. mansoni by RT-PCR}

Total RNA isolated from liver or intestine of all mice were used to analyze the expression of VEGF and FGF2 by RT-PCR as described previously (Shariati et al., in press)[11]. Briefly, total cellular was isolated with the Rneasy Mini Kit (Qiagen GmbH, Hilden Germany), according to manufactures instructions. Resulting RNAs were reverse 
transcribed with the First Strand cDNA Synthesis kit (Roche), according to manufactures instructions. Primers specific for rat VEGF were sense, 5'CTGCTCTCTTGGGTGCACTGG-3' and anti-sense, 5'- CACCGCCTTGGCTTGT CACAT-3'. VEGF-PCR reaction were carried out through reverse transcription incubation at $94^{\circ} \mathrm{C}$ for $5 \mathrm{~min}, 35$ cycles of $94^{\circ} \mathrm{C}$ for $1 \mathrm{~min}, 55^{\circ} \mathrm{C}$ for $1 \mathrm{~min}, 72^{\circ} \mathrm{C}$ for $1 \mathrm{~min}$ and a single cycle at $72^{\circ} \mathrm{C}$ for 7 min. Primers specific for detection of FGF2 were sense, 5'GCCGGCAGCATCACTTCGCT-3' and anti-sense, 5'CTGTCCAGGCC CCGTTTTGG-

$3^{\prime}$. FGF2-PCR reaction were carried out through reverse transcription incubation at $94^{\circ} \mathrm{C}$ for $2 \mathrm{~min}, 50$ cycles of $94^{\circ} \mathrm{C}$ for 30 seconds, $60^{\circ} \mathrm{C}$ for 30 seconds, $72^{\circ} \mathrm{C}$ for $1 \mathrm{~min}$ and a single cycle at $72^{\circ} \mathrm{C}$ for $5 \mathrm{~min}$. PCR product were analyzed by electrophoresis in agarose gel stained with ethidium bromide with glyceraldehydes 3-phosphate dehydrogenase (GAPDH) as internal control. Primers specific for (GADPH) were sense, 5'GGTCGGTGTGAACGGATTTG-3' and GAPDH anti-sense, 5'GTGAGCCCCAGCCTTCTCCAT -3’ that were used as positive control[11].

VEGF and FGF2 expression in alveolar macrophage stimulated with different antigens of Schistosoma mansoni

Macrophages were obtained from male Wistar rats of 250-300g by bronchoalveolar lavage (BAL) as previously described[12]. Rats were euthanized with an intraperitoneal of sodium pentobarbital (100 mg/kg bw). Lungs were lavaged with aliquots of $5 \mathrm{ml}$ of sterile phosphate-buffered saline (PBS, pH 7.4) using sterile Teflon catheter (VYCON Code 123.06, lot 220987, Vigon, Spain) for collection of BAL fluid. The fluid was immediately withdrawn by gentle suction. Lavage fluid was collected in $50 \mathrm{ml}$ tubes and centrifuged at $1000 \mathrm{~g}$ at $4^{\circ} \mathrm{C}$ temperature to pellet the cells.

The cells were suspended in $1 \mathrm{ml}$ fresh complete medium containing $44 \mathrm{ml}$ of Dulbecco's Modified Eagle Medium (DMEM), $2 \mathrm{mM}$ glutamine, 10\% heat inactivated fetal bovine serum (FBS) and antibiotic solution[(with 10,000 units penicillin and $10 \mathrm{mg}$ streptomycin per ml) (Sigma Chemical Co, St Louise, MO)]. Viability of cells was estimated by the mitochondrial reduction of MTT (3-[4, 5-dimethyl-thiazol-2-yl]-2.5-diphenyl tetrazlium bromide) (Sigma) to formazan which was found to be more than $87.5 \%$ accordance with Andrade et al [13]. Cells were then counted, seeded in a 12-Well Cell Culture Cluster (Corning, NY 14831 USA) at the density of $1 \times 10^{6}$ cells/well and incubated at $37{ }^{\circ} \mathrm{C}$ in $5 \%$ CO2 incubator (RS Biotech, Galaxy). After 2 h, non-adherent cells were washed away with sterile PBS and adherent cells (macrophages) were incubated in fresh complete medium. 
Cells were treated with a dose of $10 \mu \mathrm{g} / \mathrm{ml}$ lipopolysaccharide (LPS; Sigma; positive control) and 0.1-50 $\mu \mathrm{g} / \mathrm{ml}$ of $S$ mansoni antigens (AWASm and CSm). Non-stimulated macrophages were used as negative control. All experiments were performed in triplicate.

Total RNA was extracted from alveolar macrophages using an RNeasy Mini Kit (Qiagen $\mathrm{GmbH}$, Hilden Germany.). A total of $1 \mu \mathrm{g}$ RNA was used as template for the first-strand DNA synthesis. Primers specific and PCR reactions for VEGF, FGF2 and GAPDH were done as above.

\section{Ethics Statement}

The HUIGC (Hospital Universitario Insular de Gran Canaria)-IRB approved an oral consent process that included a written summary and a short form. The oral presentation and the short form were made in a language understandable to the subject. The interpreter (witness) was fluent in both the language of the participant and the language of the consent. The written summary was signed by the 1) witness and 2) person obtaining consent. The short form was signed by the 1) witness and 2) the participant or participant's legally authorized representative.

Mice were housed and handled under standard animal laboratory conditions according to the EU regulations. All animal procedures were approved by the University of Salamanca Animal Care and Committee.

\section{Statistical analysis}

Data of VEGF in human sera, number of eosinophils and epidemiological data of human population were reported as mean \pm standard deviation (SD). Linear regression was performed with INSTAT programme. The overall differences among groups were compared by non-parametric Kolmogorov-Smirnov analysis. Data of parasite recovery, eggs per gram of liver or intestine in mice, blood cells and serological data were reported as mean \pm SD. Differences in mice groups were performed by analysis of variance (ANOVA). When global differences were detected a post-ANOVA test using the Fisher least significant differences (LSD) analysis was applied. Differences between means were considered statistically significant at $p<0.05$. All statistical analyses were performed using Statworks, Statview 4.5 and INSTAT software packages for an IBM computer. 


\section{Results}

\section{Evaluation of VEGF detection protein in human population}

Result showed significantly differences in VEGF detection protein between patients with schistosomiasis and healthy control patients $(p<0.05)$ (Table 1). Also, no differences were found between patients infected with $S$. mansoni and S. haematobium. Moreover, it was not observed any differences between patients diagnosed with other helminthoses (filariasis and hookworms infections) and healthy control patients. In addition, association between VEGF detection protein and number of eosinophils were not observed (Figure 1).

\section{Evaluation of the effects of endostatin on Schistosoma mansoni infection in a murine experimental model}

We studied the number of parasite recovery and eggs per gram in liver and intestine separately counted on day 46 post-infection. The mean number of worms recovery is $6.67 \pm$ 0.5 in mice infected with $S$. mansoni and $5.5 \pm 0.6$ in mice infected and treated with endostatin. Although the parasite recovery in infected group with $S$. mansoni were higher than mice treated with endostatin, these differences were not statistically significant. The mean number of eggs per gram in liver in the group of infected animals was significantly higher $(p<0.05)$ than mice treated with endostatin (Figure 2). Moreover, the mean number of eggs per gram in small intestine in mice infected was higher than mice treated with endostatin but differences were not significant (Figure 2). We also studied the number of granulomas from liver in $S$. mansoni mice infected compared with mice treated with endostatin. The results showed that the mean number of granulomas in mice infected group was significantly higher than mice treated with endostatin $(p<0.05)$ (Figure 3$)$.

Red blood cells and platelet counts did not show any difference between groups. Only there was existed an increasing of the number of eosinophil in mice infected with $S$. mansoni $(0.112 \pm 0.032)$ in compared with mice treated with endostatin $(0.065 \pm 0.023)$ but differences was not significant (data not shown).

Specific IgG, IgG1 and IgG2a S. mansoni antibodies are shown in Figure 4. Specific IgG and IgG1 S. mansoni antibodies had not reduction between $S$. mansoni infected group and mice treated with endostatin. On the other hand, IgG2a antibodies detection presented statistical differences $(p<0.05)$ in mice infected and treated with endostatin.

RT-PCR in liver showed that VEGF-mRNA expression decreased in mice treated with endostatin in comparison with mice infected with S. mansoni (Figure 5). Similarly, FGF2 
expression in liver also decreased in mice treated with endostatin in comparison with mice infected with S. mansoni (Figure 5). In contrary, VEGF and FGF2-mRNA expression in intestine did not show differences between $S$. mansoni infected group and mice treated with endostatin (Figure 6).

\section{Evaluation of the effects of Schistosoma mansoni antigens on the VEGF and FGF2 production by rat alveolar macrophages}

We studied the effects of different concentrations of different antigens of S. mansoni $(0.1-50 \mu \mathrm{g} / \mathrm{ml})$ on the VEGF and FGF2 expression in alveolar macrophages (Figure 7). The result indicated that macrophages stimulated with $50 \mu \mathrm{g} / \mathrm{ml}$ of cercarial antigen of $S$. mansoni (CSm) were able to induce VEGF and FGF2 mRNA expression (Figure 7A). On the other hand, macrophages stimulated with adult worm antigens of S. mansoni (AWASm) were not able to produce VEGF and FGF2 angiogenic factors (Figure 7B).

\section{Discussion}

The main helminthoses that affect the human population are geohelmintosis, schistosomiasis and filariasis[14]. These same worms also are responsible for parasitic infection in immigrant patients asymptomatic with absolute or relative eosinophilia $[15,16]$. In the present work we evaluated VEGF concentration in the sera of patients with parasitological diagnosis of schistosomiasis, filariasis and hookworms infections. We selected patients from sub-Saharan Africa with eosinophilia who showed the presence of a single worm, not co-infection. We found that patients diagnosed of schistosomiasis had a high level of VEGF in sera compared with healthy patients group. These results are similar to those reported by other authors in S. mansoni infections [17]. We observed that there were no significant differences between VEGF levels in patients with schistosomiasis produced by $S$. mansoni and $S$. haematobium. Angiogenesis plays a fundamental role in many physiological and pathological processes, including the development of hepatic fibrosis. In cirrhosis, blood serum levels of VEGF are decreased[18]. However, high VEGF levels were detected in sera of patients with schistosomiasis, although controversial results were found in the VEGF detection among the different clinical phases of schistosomiasis $[17,19]$. In addition, we observed that eosinophils are not involved in the expression of VEGF in humans because there was no association between number of eosinophils and VEGF detection in different helminthoses. 
Secondly, we studied the effects that occur after inhibition of angiogenic factors in a experimental murine model of S. mansoni. We use endostatin as a specific inhibitor of angiogenesis[20]. The results showed that there was not significant reduction in the number of adult worms in mice infected with a significant reduction in the number of eggs in liver and number of granulomas in mice treated with endostatin compared with $S$. mansoni infected mice. This indicates that the inhibition of angiogenesis induced a decreasing of injury characteristics trigger hepatic formation of the granuloma and subsequent fibrosis.

Moreover, we studied the mechanisms involved in the reduction of injury. Firstly, we analyzed data of the blood cells count (red, white blood and platelet cells). No significant differences in count of blood cells (specifically in eosinophils) were found between $S$. mansoni infected mice and mice treated with endostatin. The results obtained in this experiment are consistent with observations in count of eosinophils in human population infected with schistosomiasis, filariasis and hookworm infections. This is opposite to that found by our group when we analyzed the relationship between angiogenesis and strongyloidiasis (paper in press). Secondly we proved the decreasing of the expression of VEGF and FGF2 in liver. This data showed the effective inhibition realised by endostatin. Thirdly, we analyzed the immune response produced in mice infected and treated with endostatin. We found a decreasing significantly in the detection of specific $\operatorname{IgG} 2 \mathrm{a}$ antibodies. This is associated with down-regulated Th1 responses in animals treated with endostatin which the reduction of number of eggs and granulomas in liver were observed. These results agree with observations by other authors in which severe schistosomiasis is associated with persistently elevated pro-inflammatory T-helper-1 (Th1)-type cytokines, whereas milder pathology is present when Th2 cytokines dominate [21]. Moreover, shift toward Th1-type cytokine production by a numerically stable population of CD4 T cells correlates with severe exacerbation of immunopathology in schistosomiasis [22].

Finally, the last objective of our study was to identify S. mansoni antigens involved in the expression of VEGF and FGF2 angiogenic factors by alveolar macrophages. We used cercarial (CSm) and adult worms (AWASm) S. mansoni antigens. Our results showed that cercarial antigens were able to stimulate alveolar macrophages to produce VEGF and FGF2 factors. Our results and the data obtained by Loeffler et al[23] where products secreted by Schistosoma eggs may promote angiogenesis within hepatic granulomas by up-regulating endothelial cell VEGF, shown the role of angiogenesis in schistosomiasis and its participation in the granulomatous reaction associated to the injury produced. 
In summary, this study show the role of angiogenesis in the pathogenesis of schistosomiasis based on three aspects: (i) VEGF detection in patients diagnosed of schistosomiasis, (ii) reduction of eggs recovery and granuloma formation in liver in mice treated with endostatin with down-regulated Th1 immune response (iii) cercarial antigen of S. mansoni stimulated VEGF and FGF2 production by alveolar macrophages.

\section{Acknowledgment}

We would like to thanks Dr Dunne and Dr Doenhoff for advice and technical assistance for technology of preparation of $S$. mansoni antigens.

\section{References}

1. Gryseels, B., et al., Human schistosomiasis. Lancet, 2006. 368(9541): p. 1106-18.

2. Van de Vijver, K.K., et al., The host's genetic background determines the extent of angiogenesis induced by schistosome egg antigens. Acta Trop, 2006. 99(2-3): p. 24351.

3. Silva, L.M., et al., Characterization of the vascular changes in schistosomal portal (pipestem) fibrosis of mice. Acta Trop, 2006. 98(1): p. 34-42.

4. Stadecker, M.J., The development of granulomas in schistosomiasis: genetic backgrounds, regulatory pathways, and specific egg antigen responses that influence the magnitude of disease. Microbes Infect, 1999. 1(7): p. 505-10.

5. Carmeliet, P. and R.K. Jain, Angiogenesis in cancer and other diseases. Nature, 2000. 407(6801): p. 249-57.

6. Baptista, A.P. and Z.A. Andrade, Angiogenesis and schistosomal granuloma formation. Mem Inst Oswaldo Cruz, 2005. 100(2): p. 183-5. 
7. Freire, N., et al., A comparative parasitologic study on Biomphalaria glabrata snail and $\mathrm{C} 3 \mathrm{H} / \mathrm{He}$ mice infected with human and murine isolates of Schistosoma mansoni derived from Sumidouro, Rio de Janeiro, Brazil. Mem Inst Oswaldo Cruz, 2003. 98(6): p. 783-7.

8. Chatterjee, S., et al., Prolonged somatostatin therapy may cause down-regulation of SSTR-like GPCRs on Schistosoma mansoni. J Vector Borne Dis, 2007. 44(3): p. 16480.

9. Dunne, D.W., et al., The isolation of a $22 \mathrm{kDa}$ band after SDS-PAGE of Schistosoma mansoni adult worms and its use to demonstrate that $\operatorname{IgE}$ responses against the antigen(s) it contains are associated with human resistance to reinfection. Parasite Immunol, 1997. 19(2): p. 79-89.

10. O'Reilly, M.S., et al., Endostatin: an endogenous inhibitor of angiogenesis and tumor growth. Cell, 1997. 88(2): p. 277-85.

11. Shariati, F., et al., Trichinella: differential expression of angiogenic factors in macrophages stimulated with antigens from encapsulated and non-encapsulated species. Exp Parasitol, 2009. 123(4): p. 347-53.

12. Porter, D.W., et al., Nitric oxide and reactive oxygen species production causes progressive damage in rats after cessation of silica inhalation. Toxicol Sci, 2006. 90(1): p. 188-97.

13. Andrade, M.A., et al., Echinococcus multilocularis laminated-layer components and the E14t 14-3-3 recombinant protein decrease NO production by activated rat macrophages in vitro. Nitric Oxide, 2004. 10(3): p. 150-5.

14. Watkins, B.M., Drugs for the control of parasitic diseases: current status and development. Trends Parasitol, 2003. 19(11): p. 477-8.

15. Pardo, J., et al., Helminth-related Eosinophilia in African immigrants, Gran Canaria. Emerg Infect Dis, 2006. 12(10): p. 1587-9.

16. Carranza-Rodriguez, C., et al., Cryptic parasite infection in recent West African immigrants with relative eosinophilia. Clin Infect Dis, 2008. 46(6): p. e48-50.

17. Tawfeek, G.M., A.M. Alafifi, and M.F. Azmy, Immunological indicators of morbidity in human schistosomiasis mansoni: role of vascular endothelial growth factor and antisoluble egg antigen IgG4 in disease progression. J Egypt Soc Parasitol, 2003. 33(2): p. 597-614. 
18. Shi, B., X. Wang, and Z. Yang, Vascular endothelial growth factors and liver diseases. Hepatogastroenterology, 2001. 48(40): p. 1145-8.

19. de Toledo, C.F., et al., Endothelial markers in schistosomiasis patients with or without portal hypertension. Dig Dis Sci, 2009. 54(6): p. 1331-6.

20. Abdollahi, A., L. Hlatky, and P.E. Huber, Endostatin: the logic of antiangiogenic therapy. Drug Resist Updat, 2005. 8(1-2): p. 59-74.

21. Stadecker, M.J., et al., The immunobiology of Th1 polarization in high-pathology schistosomiasis. Immunol Rev, 2004. 201: p. 168-79.

22. Rutitzky, L.I., et al., Enhanced egg-induced immunopathology correlates with high IFN-gamma in murine schistosomiasis: identification of two epistatic genetic intervals. J Immunol, 2005. 174(1): p. 435-40.

23. Loeffler, D.A., et al., Soluble egg antigens from Schistosoma mansoni induce angiogenesis-related processes by up-regulating vascular endothelial growth factor in human endothelial cells. J Infect Dis, 2002. 185(11): p. 1650-6. 


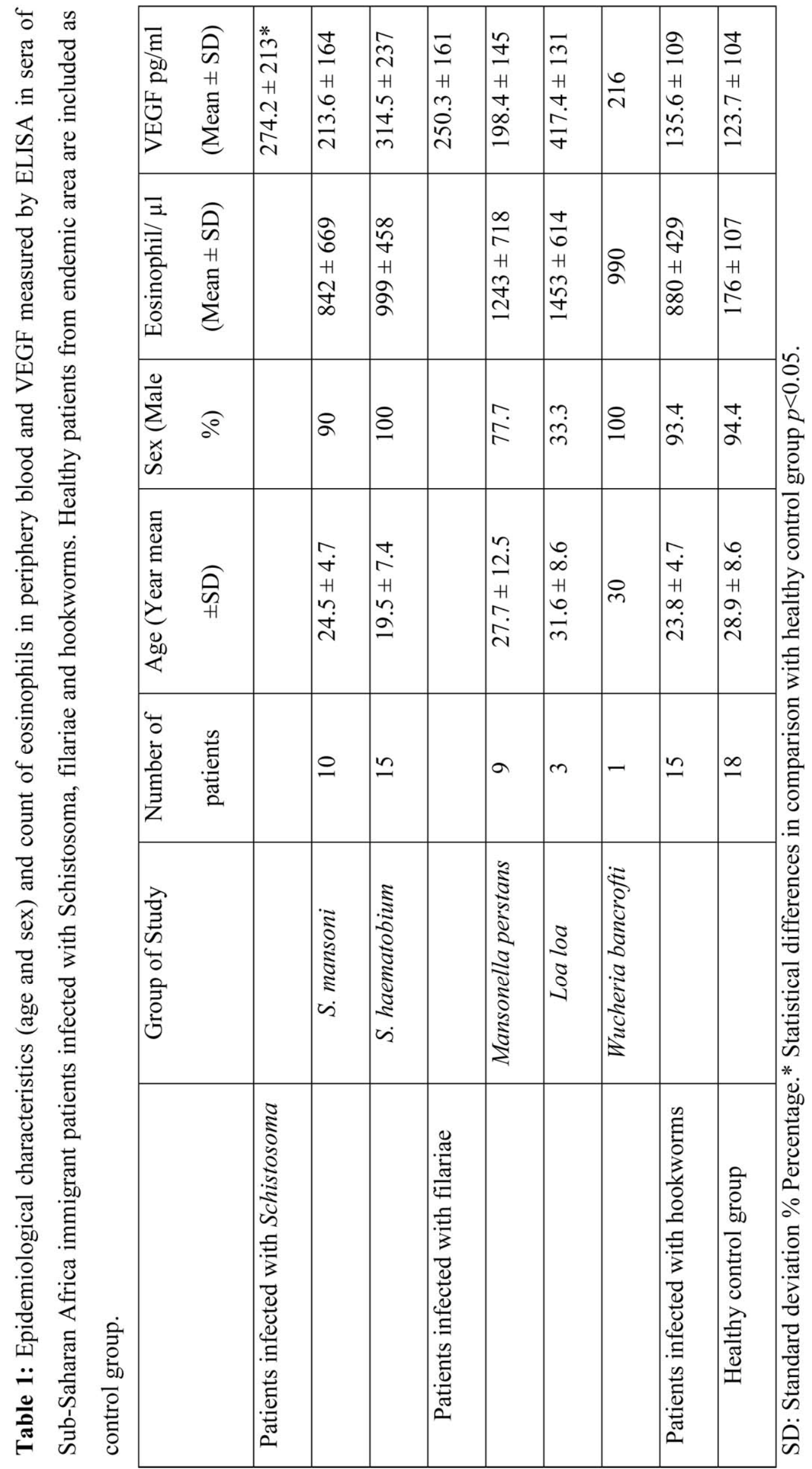




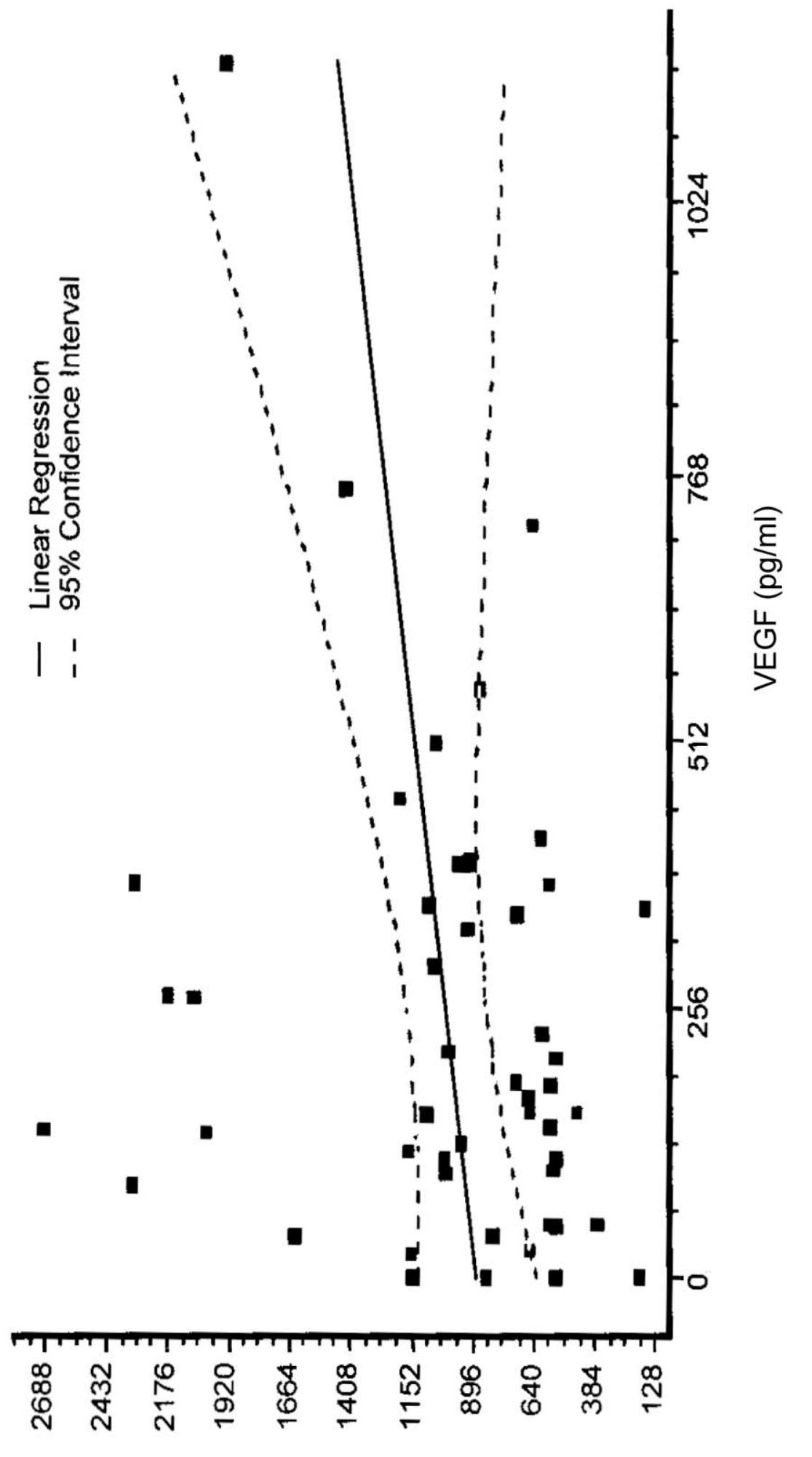

독 엄

定这

ญ तิ ह

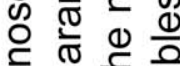

흄 $\frac{5}{\sqrt{0}}$

잉 유

๗ 을 읋

듕 응 둥

事

ऽ क

드은 은 을

응 원은

든 흥

응

त

운 造

잉

तั $\frac{1}{\frac{1}{\pi}}$

등 을

도응

व

山 $\frac{1}{0} \frac{0}{0}$

品 $\frac{\pi}{4}$

.

즐 웜

ह 윰

O 요이

오 号至恋

드 ᄂัญ 엉

क त



ठ্ঠ

$\overline{\mathrm{\sigma}}$

인 잉

岕芯

$\because . \cong$ 号

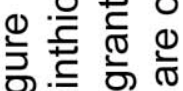

婂就

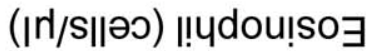




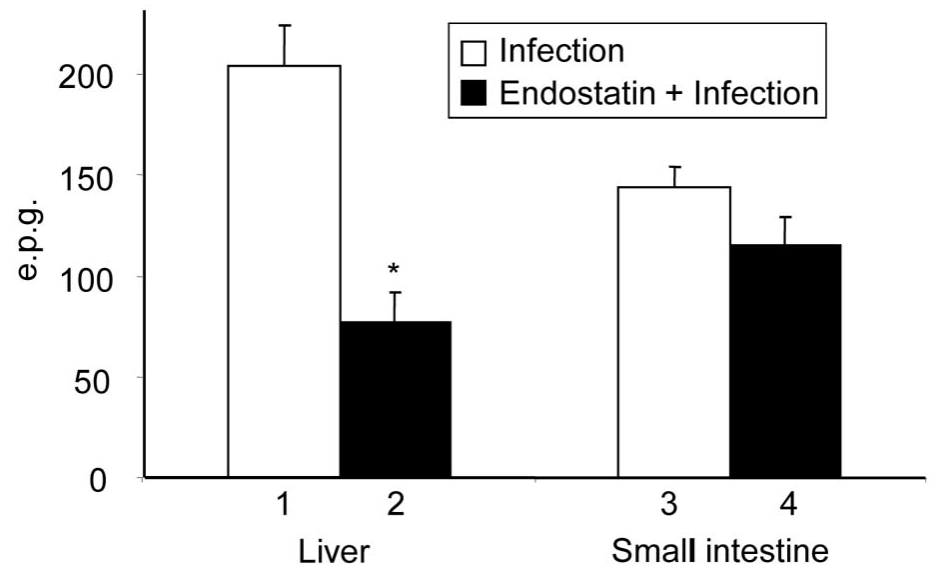

Figure 2: Determination of $S$. mansoni eggs in liver and intestine. Mice were divided in two groups. ( $i$ ) mice infected with $S$. mansoni and necropsy 7 week pi and (ii) mice infected with $S$.mansoni and treated with endostatin, necropsied 7 week pi $* p<0.05$. 


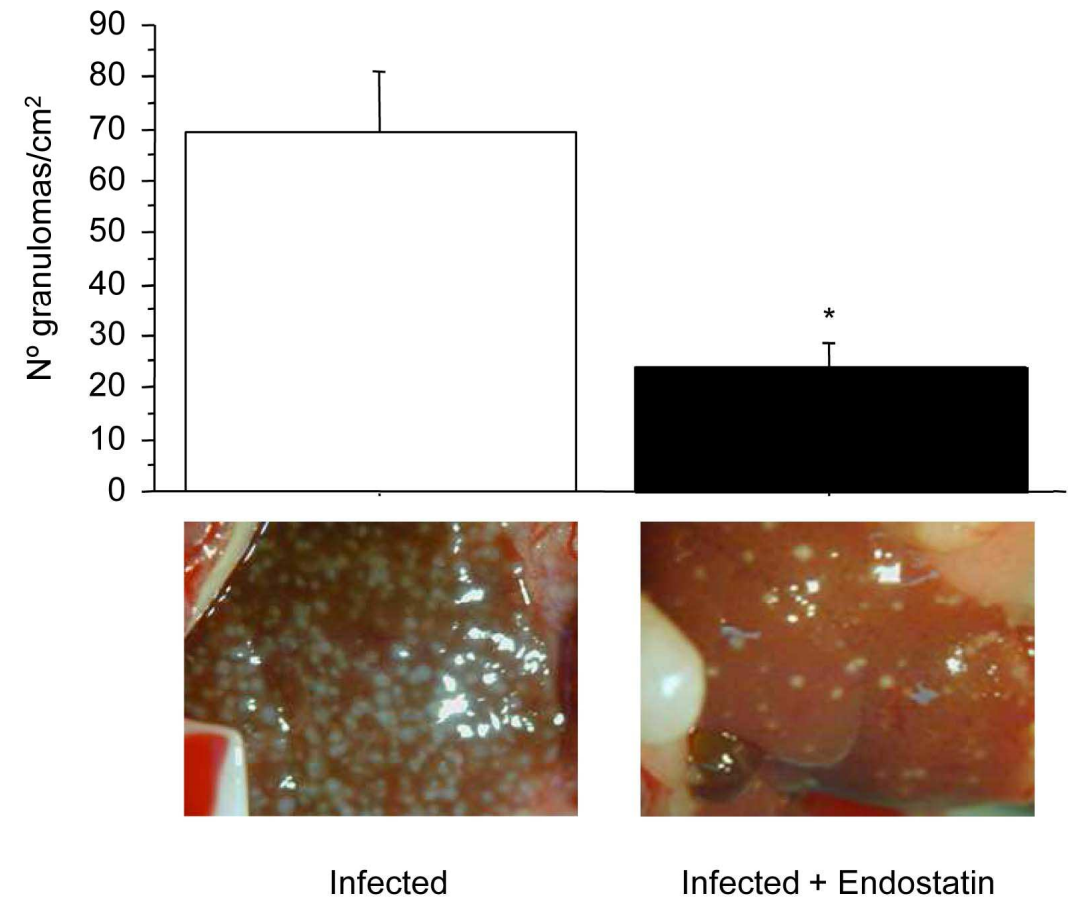

Figure 3: Number of granulomas on liver surface. Hepatic granulomas on liver surface $/ \mathrm{cm}^{2}$ were counted in two groups. (i) mice infected with $S$. mansoni and necropsy 7 week pi and (ii) mice infected with $S$.mansoni and treated with endostatin, necropsied 7 week pi. The results are expressed as mean \pm standard error. An illustration of liver granulomas of treated and untreated control group is shown. ${ }^{*} p<0.05$. 


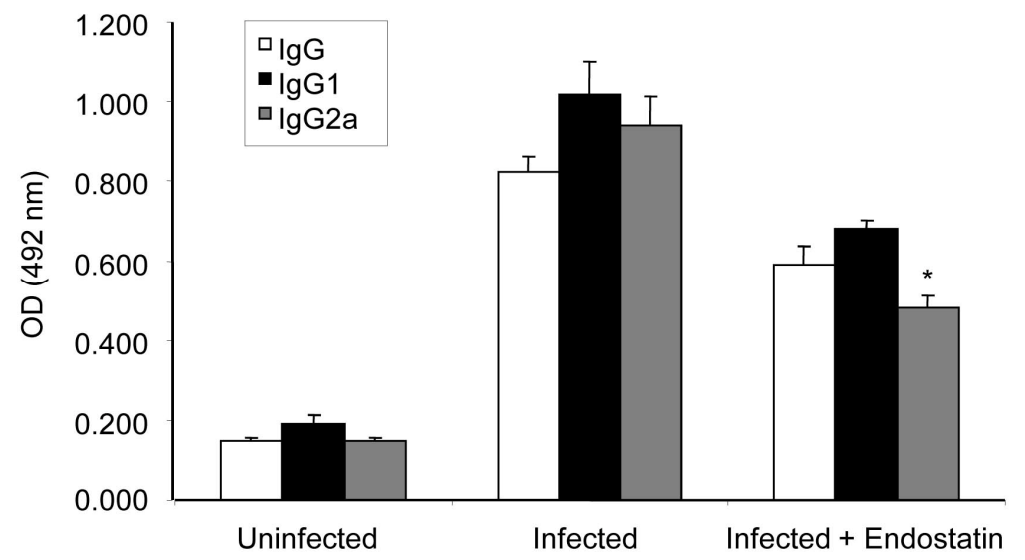

Figure 4: Detection of $\operatorname{IgG}, \operatorname{IgG} 1$ and $\operatorname{IgG} 2$ a specific antibodies by ELISA. Sera of three groups as (i) uninfected mice (ii) mice infected with $S$. mansoni (iii) mice infected with $S$.mansoni and treated with endostatin were analyzed. IgG (white colour), IgG1 (black colour) and IgG2a (grey colour) $* p<0.05$. 

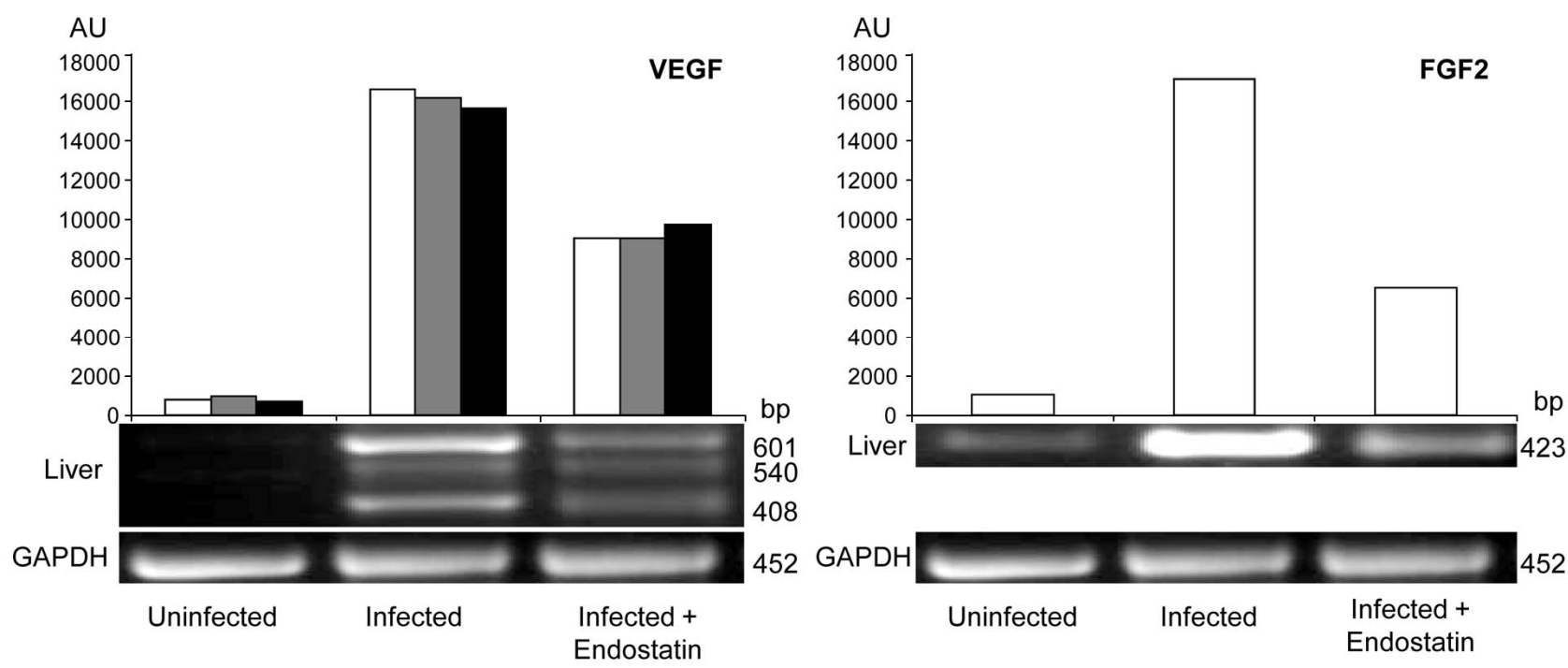

Figure 5: Detection of VEGF and FGF2 by RT-PCR in liver. Three experimental groups were used: (i) uninfected mice (ii) mice infected with $S$. mansoni (iii) mice infected with $S$.mansoni and treated with endostatin. VEGF was expressed as three bands and arbitrary units (AU) calculated by densitometry of each band $601 \mathrm{bp}$ (white bars), $540 \mathrm{bp}$ (grey bars), and $408 \mathrm{bp}$ (black bars). FGF2 expression showed a band with 423bp (white bars) and densitometry analysis of it as arbitrary unit (AU). GAPDH expression was used as internal control. 

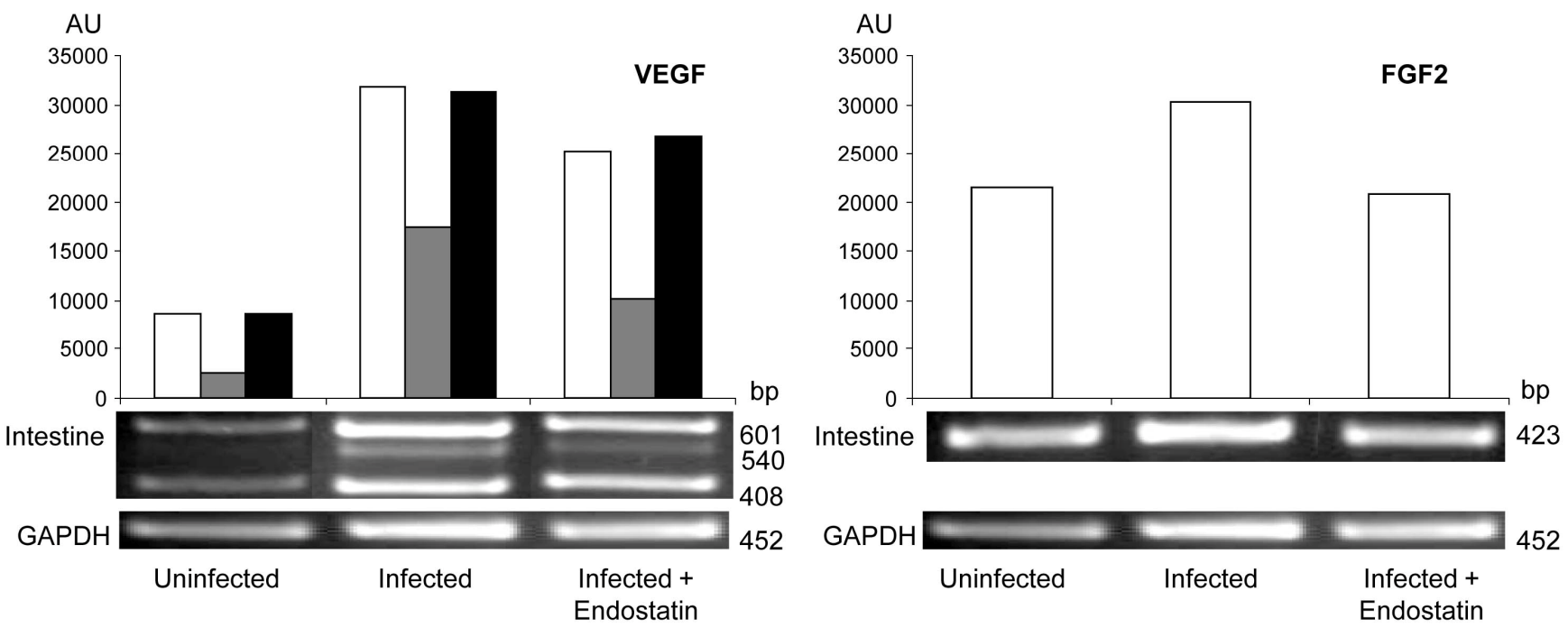

Figure 6: Detection of VEGF and FGF2 by RT-PCR in intestine. Three experimental groups were used: (i) uninfected mice (ii) mice infected with $S$. mansoni (iii) mice infected with $S$.mansoni and treated with endostatin. VEGF was expressed as three bands and arbitrary units (AU) calculated by densitometry of each band $601 \mathrm{bp}$ (white bars), $540 \mathrm{bp}$ (grey bars), and $408 \mathrm{bp}$ (black bars).FGF2 expression showed a band with 423bp (white bars) and densitometry analysis of it as arbitrary unit (AU). GAPDH expression was used as internal control. 

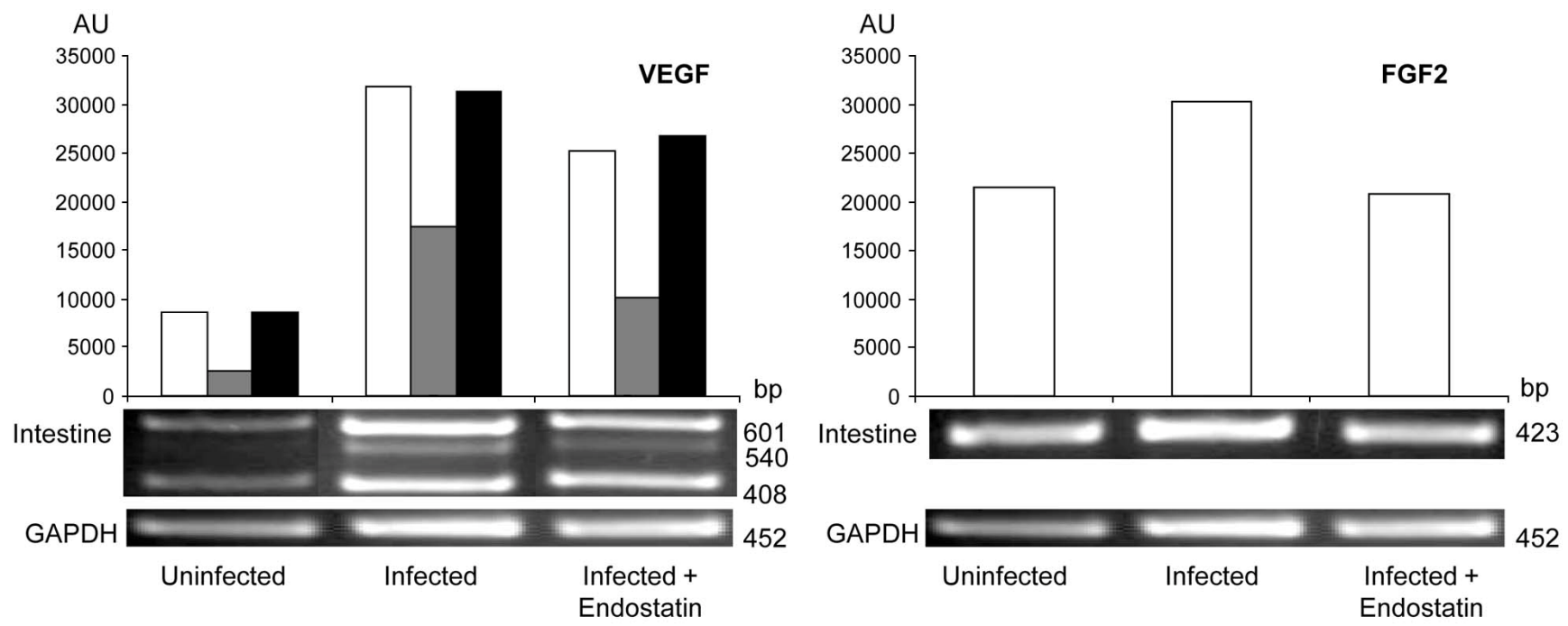

Figure 7: Effect of Schistosoma mansoni antigens on VEGF and FGF2 in alveolar macrophages. mRNA expression in rat alveolar macrophages stimulated with cercarial antigen of S. mansoni (A), and adult worm S. mansoni antigen (B). GAPDH mRNA expression levels from rat macrophages detected by RT-PCR are used as internal positive control (C). Non-stimulated, negative control $(\varnothing)$, LPS stimulated macrophages, positive control (LPS) and different concentrations of S. mansoni antigens, $0.1-50 \mu \mathrm{g} / \mathrm{ml}$. Arbitrary units are calculated by densitometry of corresponding amplicons. 


\section{Conclusions}


1. - The antigens of encapsulated species Trichinella spiralis are able to stimulate in a dose-dependent manner, angiogenic factors (VEGF and FGF2) in rat alveolar macrophages.

2. - Angiogenesis plays an important role in primary infection by Strongyloides venezuelensis, as its inhibition by using endostatin causes a decrease in magnitudes of infection.

3 .- The endostatin reduces infection of Strongyloides venezuelensis not by direct action on the parasite but through indirect effects such as decreased production of angiogenic factors by host and / or reduction of the eosinophilic response.

4. - The larval somatic antigens of Strongyloides venezuelensis are responsible for the induction of angiogenic factors and their modulation is related to the generation of nitric oxide.

5. - In patients with schistosomiasis there is an increased VEGF levels in serum with significant differences compared with other diseases due to helminths.

6. - Inhibition of angiogenesis by endostatin in murine experimental schistosomiasis induces a decrease in the number of eggs in liver, as well as in the presence of granulomas and hepatic fibrosis.

7 .- The cercariae $S$. mansoni antigens induce the expression of angiogenic factors in rat alveolar macrophages. 


\section{Resumen en español}


El conocimiento sobre el control de la angiogénesis ha sido un gran avance en la comprensión de la patogénesis de muchas enfermedades en las últimas décadas. Los estudios sobre el papel de los factores angiogénicos y antiangiogénicos en la biología del crecimiento neoplásico, crecimiento del tumor y el desarrollo de las metástasis, son los más abundantes en la literatura. Sin embargo, tanto la generación como la inhibición de nuevos vasos desempeñan un papel importante en otros procesos fisiopatológicos, por ejemplo isquemia, infección e inflamación. La revisión bibliográfica de esta Tesis Doctoral está estructurada en tres secciones: en primer lugar analizamos los conceptos básicos de la angiogénesis y vasculogenesis, así como su papel en las enfermedades neoplásicas y no neoplásicas. En un segundo apartado estudiamos las características de los dos principales factores angiogénicos: VEGF (factor de crecimiento del endotelio vascular) y FGF-2 (factor de crecimiento de fibroblastos). Específicamente se indican las características estructurales de los factores y el mecanismo biológico de acción. Además, describimos factores antiangiogénicos como por ejemplo la endostatina, un potente inhibidor de la proliferación y migración. Por último, analizamos el papel de los factores angiogénicos y antiangiogénicos en la patogénesis de las helmintosis. Al respecto, hemos encontrado escasa información y limitada al estudio de la esquistosomosis, filariosis e infecciones por Taenia solium y Trichinella spp.

Los vertebrados, incluyendo las especies de mamíferos, tienen un sistema de circuito cerrado para el suministro de nutrientes y oxígeno a los tejidos. Los vasos sanguíneos presentan dos tipos principales de células, células endoteliales que recubren el interior de los vasos y células del músculo liso que regulan la contracción y la dilatación de los vasos 
sanguíneos. Desde el punto de vista embriológico, los vasos sanguíneos tienen dos etapas principales: vasculogénesis (formación de vasos sanguíneos a partir de células precursoras) y angiogénesis (formación de vasos sanguíneos a partir de vasos preexistentes y de células del endotelio vascular). La angiogénesis desempeña un papel importante en diversos procesos fisiológicos y patológicos, incluyendo el desarrollo embrionario, la cicatrización, la inflamación y el crecimiento tumoral. Tanto la liberación no controlada de los factores angiogénicos como la alteración de la producción natural de los inhibidores de la angiogénesis, con la consiguiente modificación del equilibrio angiogénico, son responsables de la proliferación incontrolada de células endoteliales que tiene lugar durante la neovascularización en la angiogénesis tumoral y en enfermedades asociadas.

Folkmann en 1971 propuso que el crecimiento de tumores y metástasis dependen de la angiogénesis y por tanto su bloqueo puede ser una estrategia para detener el crecimiento tumoral. En las etapas iniciales de los tumores malignos hay un equilibrio entre la proliferación de células neoplásicas y su destrucción, tanto por apoptosis como por control inmunológico. Cuando el tumor primario alcanza un tamaño crítico, disminuye la concentración de oxígeno y las células producen factores angiogénicos. Por otra parte, la destrucción del tejido conduce a la producción de sustancias antiangiogénicas. La vida media de factores antiangiogénicos es mayor que el crecimiento tumoral y las metástasis en desarrollo. Sin embargo, cuando el equilibrio se altera a favor de la actividad proangiogénica, la formación de nuevos vasos se lleva a cabo con las consecuencias que se indican en las secciones siguientes. Factores pro-angiogénicos incluyen varias moléculas liberadas por las células del parénquima o por células inflamatorias en respuesta a factores mecánicos, metabólicos (por ejemplo, hipoxia, acidosis) o respuesta inmune. Por otra parte, la destrucción del tejido conduce a la generación de moléculas con potencial antiangiogénico. El predominio de los factores angiogénicos conduce a la formación de 
nuevos vasos sanguíneos a partir de precursores endoteliales locales y a partir de la médula ósea.

En la angiogénesis tumoral están implicados tanto los vasos sanguíneos como los vasos linfáticos. Los vasos sanguíneos se pueden considerar anormales con respecto a la vascularización normal. Por lo tanto, macroscópicamente la distribución es muy desorganizada con dilatación de vasos tortuosos, con un diámetro irregular y un número excesivo de ramificaciones. Microscópicamente, el endotelio tiene numerosas aberturas con las uniones intercelulares ampliadas y la membrana basal discontinua o ausente. El músculo liso que rodea las células endoteliales no se contrae en respuesta a los estímulos normales, lo que limita el uso de vasoconstrictores en el tratamiento contra los tumores. Las principales alteraciones de los vasos linfáticos son la compresión de los vasos localizados en el tumor y la dilatación de los situados en la periferia por exceso de VEGF-C . Estos vasos linfáticos pueden recoger las células neoplásicas derivadas de la superficie del tumor y facilitar así la metástasis linfática.

Las modificaciones vasculares descritas en la parte anterior determinan el flujo sanguíneo caótico intratumoral con aparición de zonas de hipoxia y acidosis, que pueden seleccionar células que han perdido la respuesta apoptótica a la hipoxia y por tanto amplian la clonación. Por otra parte, los factores angiogénicos puede modular la expresión de moléculas de adhesión celular y otros marcadores de la superficie del tumor del endotelio vascular. Por ejemplo, VEGF y el factor de necrosis tumoral- $\alpha$ (TNF- $\alpha$ ) aumentan el número de moléculas de adhesión, mientras que el factor de crecimiento de fibroblastos (FGF) y el factor de crecimiento transformante $\beta 1$ (TGF- $\beta 1)$ disminuye el número de moléculas de adhesión.

La inflamación y la hipoxia contribuyen a la angiogénesis en las enfermedades no neoplásicas. En un adulto sano, las células endoteliales de los vasos sanguíneos se 
encuentran en estado de reposo. En presencia de hipoxia o remodelación de la inflamación vascular ocurre la formación de nuevos vasos. Un aspecto de particular interés es que la angiogénesis en enfermedades no neoplásicas permiten la formación de nuevos vasos con estructura y función normal. La hipoxia es un estímulo muy importante de la angiogénesis así como de otros procesos biológicos que tratan de restaurar la oxigenación de los tejidos normales. El mecanismo básico es la activación de una proteína llamada HIF-1 (factor inducible de hipoxia 1). HIF-1 es una proteína heterodimérica formada por la unión de dos subunidades (HIF-1 $\alpha$ y HIF-1 $\beta$ ). Mientras HIF-1 $\beta$ se expresa de modo constitutivo en todos los tejidos, HIF-1 $\alpha$ se activa en condiciones de hipoxia. HIF-1 actúa en la región promotora de genes diferentes que tienen un elemento común de respuesta. Entre los genes activados por HIF-1 se encuentran genes relacionados con la angiogénesis como los que codifican para VEGF, óxido nítrico sintasa inducible (iNOS), factor del crecimiento derivado de las plaquetas (PDGF) y angiopoyetina 1 (angl). Además, durante la inflamación no hay reclutamiento ni activación de células sanguíneas circulantes hacia el foco lesional. Muchas de estas células (por ejemplo, macrófagos, plaquetas, eosinófilos, mastocitos) liberan factores pro-angiogénicos. Además, los fagocitos son capaces de producir proteasas y de estimular la liberación de factores angiogénicos de la matriz extracelular.

Los cambios en la angiogénesis (por exceso o defecto) han sido observados en enfermedades múltiples donde la hipoxia o la inflamación desempeñan un papel importante. En particular, se han producido cambios en diversos tipos de enfermedades sistémicas, tanto autoinmunes (artritis reumatoide, lupus eritematoso, esclerosis múltiple), metabólicas (diabetes mellitus) o hematológicas (enfermedad de Castleman). Por otra parte, las modificaciones en la angiogénesis se han detectado en enfermedades localizadas que afectan al tracto gastrointestinal (enfermedad de Crohn), sistema nervioso central (esclerosis 
múltiple, enfermedad de Alzheimer), respiratorio (enfisema pulmonar, fibrosis pulmonar idiopática) o riñón (glomerulonefritis).

Los factores de crecimiento del endotelio vascular (VEGFs) son una familia de moléculas producidas por diferentes tipos celulares, entre los que se encuentran los eosinófilos. Desde su descripción inicial a principios de los años 80, los estudios acerca de la estructura y función de estas moléculas se han multiplicado de forma exponencial. Los VEGFs pertenecen a la superfamilia VEGF/PDGF (platelet-derived growth factor) y poseen como característica común tener ocho residuos de cisteína, dos de ellos relacionados con la formación de puentes intermoleculares y los otros seis implicados en la formación de puentes intramoleculares con formación de 3 dominios globulares. Se han descrito siete moléculas de la familia VEGF: VEGF-A, VEGF-B, VEGF-C, PlGF (placental growth factor), VEGF-E y VEGF-F. En mamíferos, únicamente los cinco primeros tienen importancia biológica, siendo VEGF-E una proteína vírica (virus Orf) y VEGF-F una proteína presente en el veneno de serpientes (víboras). Dentro de las 5 moléculas identificadas en humanos, la que reviste mayor importancia biológica es el VEGF-A, en muchas ocasiones denominado simplemente VEFG. El gen que codifica VEGF-A está formado por ocho exones. De forma característica, el ARN mensajero sufre un procesamiento alternativo, splicing, por el que las proteínas derivadas y englobadas con la denominación genérica de VEGF o VEGF-A son diferentes. La nomenclatura general de estas proteínas incluye, además de la denominación general (VEGF) el número de aminoácidos total $(\mathrm{xxx})$ un sufijo (b) si el procesamiento alternativo afecta a la porción distal del exón 8. El número total de aminoácidos deriva principalmente de la inclusión o no de aminoácidos codificados total o parcialmente por los exones 6 y 7. Estos aspectos estructurales tienen una clara trascendencia biológica. Así, la inclusión o exclusión de los exones 6 y 7 modula las interacciones con proteoglicanos heparan sulfato (HSPGs) y 
receptores tipo neuropilina. Por otro lado, el procesamiento proximal o distal del exón 8 tiene consecuencias funcionales, ya que las isoformas $\mathrm{VEGF}_{\mathrm{xxx}}$ son proangiogénicas y las $\mathrm{VEGF}_{\mathrm{xxx}} \mathrm{b}$ son antiangiogénicas. Las isoformas principales en el ser humano de VEGF-A son $\mathrm{VEGF}_{206}, \mathrm{VEGF}_{189}, \mathrm{VEGF}_{189 \mathrm{~b}}, \mathrm{VEGF}_{165}, \mathrm{VEGF}_{165 \mathrm{~b}}, \mathrm{VEGF}_{121}$ y $\mathrm{VEGF}_{121 \mathrm{~b}}$. En las formas proangiogénicas, la isoforma que posee una mayor importancia biológica es VEGF $_{165}$, seguida de $\mathrm{VEGF}_{121}, \mathrm{VEFG}_{189} \mathrm{y}_{\mathrm{VEGF}_{206}}$.

El VEGF-A ejerce su efecto biológico a través de la interacción con los receptores de superficie celular. Los receptores para VEGFs son de 5 tipos principales: VEGFR-1 (vascular-endothelial growth factor-1), VEGFR-2 (vascular-endothelial growth factor-2), VEGFR-3 (vascular-endothelial growth factor-3), neuropilina-1 y neuropilina-2. Cada uno de los VEGFs presenta una selectividad específica por uno o varios de los receptores indicados. VEGF-A es capaz de unirse a todos ellos con excepción de VEGFR-3. VEGFR-1 (también denominado $f m s$-like tyrosine kinase; Flt-1) es una molécula constituida por 7 dominios tipo Ig extracelulares, una región transmembrana y un dominio intracelular tirosina kinasa. Esta molécula se expresa en las células endoteliales, osteoblastos, células del sistema mononuclear fagocítico, células trofoblásticas placentarias, células mesangiales y algunas células madre hematopoyéticas. Aunque la afinidad del VEGFR-1 por VEGF-A es 100 veces mayor que por VEGFR-2, su actividad tirosina kinasa es menor. En la embriogénesis, la expresión de este receptor está ligada a un efecto negativo en la angiogénesis. En periodos posteriores, la unión VEGF-A a VEGFR-1 parece que desempeña un papel importante en la generación de señales paracrinas en las células endoteliales.VEGFR-2 (también denominado KDR: kinase-insert domain receptor o flk-1: fms-like kinase) tiene una estructura muy similar a VEGF-1. Este receptor se expresa principalemente en las células endoteliales, aunque también se ha demostrado en neuronas, megacariocitos, osteoblastos y células hematopoyéticas. Las principales acciones de VEGF- 
A se ejercen por interacción con este receptor. Las neuropilinas 1 y 2 fueron identificadas como los receptores de una familia de moléculas conocidas como semaforinas/colapsinas, una familia de moléculas reguladoras del desarrollo del sistema nervioso. Ambas se expresan durante el desarrollo embrionario en tejido nervioso, cardiovascular y esquelético, mientras que en el adulto su expresión es muy amplia. El papel de las neuropilinas, principalmente de NP-1 es actuar como correceptor de VEGFR-2 aumentando su acción biológica.

Muchos tipos celulares son capaces de desencadenar la síntesis y liberación de VEGFA en respuesta a estímulos muy diferentes: modificaciones metabólicas (hipoxia, hipoglucemia), hormonales (estrógenos), citocinas y otros factores de crecimiento, moléculas proinflamatorias y alteraciones genéticas. Uno de los mejor caracterizados es la hipoxia, que induce la estabilización y translocación al núcleo de dos factores HIF (hypoxic inducible factor) $1 \alpha$ e HIF $2 \alpha$. La unión con el factor nuclear HIF1 $\beta$ con los factores HIFa, al interaccionar con una región específica del gen del VEGF (HRE, hypoxia response element) induce la síntesis de esta molécula. Por otro lado, la hipoglucemia, tanto en estudios de laboratorio como clínicos da lugar a un aumento en la síntesis de VEGF: Los estrógenos también desempeñan un papel importante en la inducción de la producción de VEGF tanto en situaciones fisiológicas (ciclo menstrual, ovulación) como patológicas (cáncer de mama). Múltiples citocinas y factores de crecimiento inducen la producción de VEGF. Entre los mediadores inflamatorios relacionados con la producción de VEGF deben destacarse los radicales libres de oxígeno y el óxido nítrico. Finalmente, varios tipos de alteraciones genéticas, presentes en enfermedades hereditarias o tumorales se asocian a hiperproducción de VEGF. Las mejor caracterizadas se relacionan con mutaciones de p53, del gen que codifica la proteína de von Hippel-Lindau, de los genes supresores PTEN (phosphatase and tensin homologue deleted on chromosome 10). 
La interacción entre VEGF-A y el receptor VEGFR-2 pone en marcha una serie de mecanismos de señalización iniciales que pueden ser resumidos en 5 fases: (i) unión del ligando al receptor, (ii) dimerización del receptor; (iii) activación de tirosina-cinasa; (iv) autofosforilación del receptor y $(v)$ unión y activación de adaptadores a los lugares de autofosforilación. La vía de señalización del VEGF/ VEGFR-2 es diferente a la de otros factores de crecimiento. Básicamente tras la interacción entre VEGF-A y VRGFR-2 se activan 4 vías de transducción: (i) Activación de PI3K que transforma PIP2 en PIP3. Esta molécula actúa de dos formas en los efectos del VEGF: inhibiendo la apoptosis (por acción sobre BAD y caspasa 9) y estimulando la producción de óxido nítrico por acción sobre la isoenzima endotelial de la ONS. (ii) activación de CDC42 finalmente conduce a una reorganización de los filamentos de actina, (iii) Disminución de la adhesión de las células endoteliales empleando como molécula adaptadora Src y (iv) activación de la fosfolipasa C gamma que partiendo de PIP2 genera DAG e IP3. Las consecuencias de esta vía son de dos tipos: la generación de prostaglandinas y la activación de la proliferación de las células endoteliales. En resumen, los cuatro mecanismos por los que VEGF conduce a la angiogénesis son: (i) aumento de la supervivencia celular, (ii) incremento en la migración celular, (iii) estimulación de la proliferación celular y (iv) facilitación de la permeabilidad.

FGF2 o factor de crecimiento de fibroblastos representa el mejor caracterizado de la familia de factores de crecimiento que unen heparina. FGF-2 es una molécula con efecto angiogénico potente in vivo e in vitro, que estimula el crecimiento de las células musculares lisas, la cicatrización de las heridas y la reparación de los tejidos. Además, el FGF-2 puede estimular la hematopoyesis y desempeñar un papel importante en la diferenciación y función del sistema nervioso, los ojos y el esqueleto. FGF-2 fue identificado como una proteína de 146 aminoácidos y más tarde como una forma proteolítica de $18 \mathrm{kDa}$. Contiene cuatro residuos de cisteína, sin bandas disulfuro intramolecular, un gran número de residuos 
básicos y dos sitios que pueden estar fosforilados por proteínas quinasas A y C, respectivamente. La interacción de FGF-2 y la heparina protege a este factor contra el calor, la desnaturalización ácida y la fragmentación mediante proteasas. Mientras que la heparina es sólo sintetizada por las células cebadas del tejido conectivo, el sulfato de heparina se distribuye ampliamente en todos los órganos y tejidos de mamíferos, unida a proteínas básicas como la heparina sulfato proteoglicanos (HSPG). HSPGs son una clase funcional de diversas moléculas que se encuentran en la superficie celular y en la matriz extracelular, donde se ha demostrado que interactúan con FGF-2 y modulan su distribución y función.

FGF-2 desempeña un papel clave en las diferentes etapas de la enfermedad en la mayoría de los órganos. Una de las actividades mejor caracterizadas es su capacidad para regular el crecimiento y la función de las células vasculares tales como las células endoteliales y del músculo liso. FGF-2 se ha implicado en el desarrollo y crecimiento de nuevos vasos sanguíneos (angiogénesis) y en la patogénesis de las enfermedades vasculares como la aterosclerosis. FGF-2 ha sido observado en el sistema nervioso de una variedad de especies. En el cerebro humano adulto, se ha encontrado en el sistema nervioso central y en las células de Purkinje del cerebelo, en los astrocitos, en poblaciones neuronales seleccionadas y ocasionalmente en las células de la microglia, encontrándose todas sus isoformas. En el pulmón, el FGF-2 se ha relacionado con la morfogénesis de la ramificación y el desarrollo de la fibrosis pulmonar. FGF-2, así como varios otros miembros de la familia FGF tales como FGF-4 y -8, estimulan el desarrollo de las extremidades. Sin embargo, es poco probable que FGF-2 sea el principal candidato para la formación de las extremidades ya que su patrón de expresión no se correlaciona con los eventos que ocurren durante la generación de estas. Los estudios de desarrollo indican que el FGF puede desempeñar un papel importante en el desarrollo muscular. 
La proliferación, diferenciación y producción de TGF- $\beta$ de osteoblastos son estimuladas por FGF-2. Además estimula la función de las células de Leydig. En el ojo, FGF-2 produce la inducción de la regeneración in vitro de la retina y protege a los fotorreceptores del daño de la luz. Por último, la proliferación y la diferenciación de los melanocitos normales humanos y las actividades de varios de los queratinocitos son dependientes de la producción de FGF-2.

Los inhibidores de la angiogénesis son sustancias que inhiben el crecimiento de nuevos vasos sanguíneos. Pueden ser endógenos (proteínas o fragmentos de proteínas que se forman en el organismo) o exógenos (fármacos o componentes de la dieta). Uno de los principales inhibidores es la endostatina, proteína de $20 \mathrm{kDa}$, procedente de la división del colágeno XVIII y que pertenece a la familia de las multiplexinas. La generación de endostatina desde el colágeno XVIII está catalizada por enzimas proteolíticos como catepsina L y metaloproteasas. Al igual que muchos otros inhibidores de la angiogénesis, endostatina tiene alta afinidad por la heparina, con un sitio que sirve de unión a la heparina. Este sitio participa en la inhibición de la angiogénesis inducida. También se une con baja afinidad a proteoglicanos sulfato de heparina, glipicano-1 y glipicano-4 y con alta afinidad a una molécula no identificada en las células endoteliales. Además se asocia con proteínas como integrinas, fibulinas, laminina-1 y tropomiosina. Por último, se ha observado que endostatina se introduce directamente en el citoplasma a través de las células endoteliales.

Las funciones de la endostatina son diversas. La más conocida es la de ser un potente inhibidor de la angiogénesis endógena y por tanto supresor de tumores. Se ha observado en animales de experimentación que si se eliminaba la endostatina, los tumores crecían dos o tres veces más rápidos. Por el contrario, cuando la endostatina se sobreexpresaba, los tumores crecían tres veces más lentos. Algunos trabajos han demostrado que los ratones deficientes en endostatina mostraban aumento de la angiogénesis. Se han encontrado niveles 
de endostatina elevados en ciertos tipos de cáncer, en líquido intratumoral, ascitis maligna y en enfermedades inflamatorias crónicas como la artritis reumatoide y la retinopatía diabética.

Existe poca información sobre el papel de la angiogénesis y los factores angiogénicos en las helmintosis, tanto en los seres humanos como en modelos experimentales. Los factores angiogénicos producidos por el parásito o por el hospedador pueden estimular la neovascularización a través de varios mecanismos. Se ha demostrado que algunos genes de C. elegans (PVF-1) codifican un factor con capacidad de unión a los receptores de VEGF de los mamíferos, VEGFR-1 (FLT-1) y VEGFR-2 (KDR), que inducen angiogénesis. Respecto a los mecanismos utilizados por el hospedador, en primer lugar, tanto los factores de crecimiento del endotelio vascular (VEGF) como el factor de crecimiento de fibroblastos (FGF-2) inducen angiogénesis directamente, mediante la estimulación y proliferación de células endoteliales, y a través de la migración y diferenciación en los vasos. En segundo lugar, otros factores angiogénicos como la interleucina 1 (IL-1) promueven indirectamente la angiogénesis mediante la estimulación de las células inflamatorias para producir VEGF. En tercer lugar, la fragmentación de proteínas angiogénicas como la heparinasa libera péptidos que estimulan los componentes del sistema inmunitario del hospedador, el cual a su vez estimula la producción de factores angiogénicos como VEGF y FGF-2. Por último, algunos factores angiogénicos estimulan los mecanismos implicados en las lesiones definitivas. De hecho, datos experimentales sugieren que la hipoxia en relación con el VEGF puede estimular la proliferación de la síntesis de colágeno tipo1 en miofibroblastos activados. Esto ha demostrado que el VEGF y la angiopoyetina-1 (Ang-1) pueden funcionar como factores autocrinos y paracrinos dependientes de la hipoxia, capaz de estimular la migración y quimiotaxis de los miofibroblastos a través de la activación de señales Ras/Erk. 
En la práctica, las principal información sobre angiogénesis y factores angiogénicos en las helmintosis se limita a las infecciones causadas por Schistosoma spp, filarias e infecciones por Taenia solium y Trichinella spp.

La esquistosomosis está causada por la infección por diferentes especies del género Schistosoma. Con la excepción de la dermatitis cercariana y el síndrome de Katayama, la base patogénica de la esquistosomosis es la formación de granulomas alrededor de los huevos del parásito. Aunque la información de la literatura es escasa, observamos que en las etapas iniciales de la esquistosomosis existe estimulación de la angiogénesis. La presencia de angiogénesis en modelos experimentales de esquistosomiosis ha quedado claramente demostrada por técnicas histológicas e inmunohistoquímicas. En este contexto es interesante señalar varios aspectos: (i) La angiogénesis es un fenómeno temprano, así que en fases evolucionadas (como las que se encuentran en los seres humanos) es difícil observar. (ii) Un aspecto importante para que se genere angiogénesis es la necesidad de exposición repetida al parásito. (iii) Los factores genéticos desempeñan un papel esencial en la respuesta angiogénica frente al helminto.

Los mecanismos por los que Schistosoma spp desencadena angiogénesis son de varios tipos y se han obtenido en estudios experimentales. Así, se han identificado moléculas reguladoras de angiogénesis derivadas de los huevos de $S$. mansoni como lisofosfatidilserina y prostanoides. También los huevos secretan factores adicionales que son capaces de estimular la proliferación y migración de células endoteliales y la fosforilación de p42/44 MAPK. Este efecto no se limita a las células endoteliales, sino también estimula las células vasculares del músculo liso. Por otra parte, antígenos solubles de huevos de $S$ mansoni (SEA) estimulan la proliferación y formación de nuevos vasos, disminuyendo la apoptosis y aumentando la expresión del gen para VEGF de las células endoteliales humanas de la vena umbilical (HUVECs). Estos hallazgos sugieren que los productos secretados por los huevos 
de Schistosoma pueden promover la angiogénesis en los granulomas hepáticos por sobreexpresión de VEGF. Por otra parte, los huevos de Schistosoma que se adhieren al endotelio promueven indirectamente la angiogénesis a través de la hipoxia y de la respuesta inflamatoria, iniciada por TNF- $\alpha$ e ICAM-1. En etapas posteriores, se desarrolla fibrosis periportal por un mecanismo en el que participan linfocitos que producen moléculas profibroticas como TGF- $\beta$ e IL-4. Por último, la infiltración de los huevos en el tejido circundante causa la migración de células inflamatorias hacia ese lugar. El sistema porta se interrumpe por completo alrededor de los granulomas y sólo se conserva muy cerca de la vena porta y de los conductos biliares. La proteolisis de la matriz extracelular mediante colágeno y metaloproteasas es un proceso anterior a la angiogénesis, pero necesario para permitir el desarrollo de una importante reacción inflamatoria. Aunque la proliferación de las células endoteliales de vasos maduros está en reposo, la presencia de múltiples células proliferativas en cada granuloma formado muestra la dinámica de la angiogénesis en la inflamación inducida por los esquistosomas.

Solamente dos grupos de investigación han estudiado el papel de los factores angiogénicos en la esquistosomosis humana y sus resultados son difícilmente comparables. Por un lado, se evaluaron 90 pacientes con esquistosomosis producida por S. mansoni clasificados en cinco grupos de acuerdo a los estudios ecográficos: infección leve, intensa, intestinal, hepatoesplénica y con fibrosis periportal. Detectaron que los niveles de VEGF se elevaban significativamente en los pacientes con esquistosomosis en todos los grupos excepto los grupos con infección leve e intestinal. Además, el nivel de VEGF se correlacionaba con la progresión de la enfermedad desde infección ligera hasta el desarrollo de fibrosis periportal. Utilizando un diseño de estudio diferente, otro grupo de investigación midió los niveles séricos de VEGF en pacientes con esquistosomosis, con o sin hipertensión portal. Estos autores no encontraron diferencias significativas entre ambos grupos, aunque 
los valores medios en el grupo con hipertensión portal eran más bajos, un hecho que coincide con los bajos niveles de VEGF detectados en pacientes con cirrosis por otras causas.

Las filariosis son enfermedades relacionadas con la infección de varios géneros y especies de nematodos (Wuchereria bancrofti, Brugia malayi, Brugia timori, Onchocerca volvulus, Loa loa, Mansonella perstans, Mansonella ozzardi y Mansonella streptocerca). La alteración de la angiogénesis se ha descrito en dos tipos de filariosis: filariosis linfática y oncocercosis. Las manifestaciones de la filariosis linfática (específicamente las infecciones relacionadas con $W$. bancrofti) clinicamente se caracterizan por la presencia de linfedema, dilatación de los vasos linfáticos, extravasación de linfa y en algunos casos desarrollo de elefantiasis. Existen trabajos donde se estudia la relación entre factores angiogénicos (y específicamente de la familia del VEGF) y la patogénesis de la filariosis linfática. Así, en un estudio longitudinal en 63 pacientes polinesios que viven en un foco hiperendémico de W. bancrofti, se asoció la presencia de quiluria con un alto nivel del factor de crecimiento del endotelio vascular (VEGF). Sin embargo, los pacientes con elefantiasis presentaron elevados niveles de endotelina-1 (ET-1). Por otro lado se han relacionado factores genéticos con la clínica de la enfermedad y la determinación de factores angiogénicos. En una cohorte de pacientes con filariasis linfática procedentes de Ghana se examinaron tres polimorfismos de VEGF-A. Los autores encontraron que el genotipo $\mathrm{C} / \mathrm{C}$ en 460 fue significativamente mayor en pacientes con hidrocele y en pacientes con niveles séricos elevados de VEGF. Por último, en una cohorte de pacientes infectados con $W$. bancrofti que tenían sobrexpresados los genotipos VEGF-C y sVEGFR-3 y que fueron tratados con doxiciclina (para la erradicación de la Wolbachia sp) tenían disminuidos VEGF-C y sVEGFR-3 y cuando llegaron a valores normales, presentaron mejoría clínica en sus síntomas. 
La oncocercosis se caracteriza por dos tipos de manifestaciones clínicas: nódulos subcutáneos relacionados con filarias adultas y lesiones oculares relacionados con las microfilarias. Los nódulos que se originan en la infección por Onchocerca volvulus tienen diferentes patrones angiogénicos. Los nódulos pequeños tienen suministro adecuado de sangre con distribución difusa en toda la matriz de los nódulos, en estrecha asociación con los vermes adultos. Los nódulos mayores tienen una zona central más densa y no bien vascularizada y en las zonas más periféricas con vascularización intensa, alimentadas por vasos superficiales y en estrecho contacto con los vermes adultos. Al menos una proteína derivada de $O$. volvulus (homóloga a una secretada por Ancylostoma) puede contribuir a la alteración de la angiogénesis.

La neurocisticercosis es una afección del sistema nervioso central (SNC) causada por la fase larvaria de Taenia solium. En esta infección se conoce la importancia de la respuesta granulomatosa. Una serie de ocho pacientes con neurocisticercosis sometidos a craneotomía para análisis histológico e inmunohistoquímico, mostró que el parásito al morir se rodea de un granuloma asociado a fibrosis, angiogénesis e infiltrado inflamatorio. Los tipos de células más abundantes fueron las células plasmáticas, linfocitos B y T (Th1), macrófagos y mastocitos. Además, se ha observado aumento de la angiogénesis en los modelos de neurocisticercosis en animales.

La triquinelosis es una infección producida por distintas especies de Trichinella en el que existe una afectación de las células del músculo estriado. Las larvas del género Trichinella inducen la transformación de los miocitos en células nodrizas que se rodean de complejas redes de vasos sanguíneos. En ratones infectados experimentalmente por Trichinella se detectaron varias anomalías de los vasos. Así, los complejos vasculares se encontraron sólo alrededor de los miocitos infectados, caracterizándose por grandes vasos que se ramificaban en vasos pequeños formando redes. Esta redes son el resultado de la 
angiogénesis de novo inducida durante la infección. En este contexto, los productos excretores/secretores derivados de larvas de $T$. spiralis y $T$. pseudospiralis están relacionados con cambios musculares (degenerativos, regenerativos) y angiogénesis.

De la revisión anterior podemos afirmar que: ( $i$ ) La angiogénesis es un proceso de formación de nuevos vasos importante no sólo en las enfermedades tumorales sino también en otras enfermedades, especificamente en helmintosis. (ii) Los estudios sobre el papel de la angiogénesis en helmintosis son escasos. (iii) No existe información bibliográfica acerca de la producción de factores angiogénicos por macrófagos ni del empleo de factores antiangiogénicos en helmintosis. (iv) Aunque se ha demostrado el papel del óxido nítrico en helmintosis y existe una relación documentada entre óxido nítrico y VEGF entre otros agentes angiogénicos, no se dispone de una información bibliográfica concreta acerca de la interacción de ambos mediadores inflamatorios en estas enfermedades parasitarias.

Teniendo en cuenta estos datos los objetivos propuestos en esta Tesis Doctoral son:

1.- Evaluar la expresión de factores angiogénicos (VEGF y FGF2) en macrófagos alveolares estimulados con diferentes antígenos procedentes de diversas fases del ciclo biológico de Trichinella spiralis, Trichinella pseudospiralis, Strongyloides venezuelensis y Schistosoma mansoni.

2.- Estudiar la relación existente entre la expresión de factores angiogénicos y la producción de óxido nítrico, utilizando inhibidores específicos de la óxido nítrico sintasa inducible.

3.- Emplear modelos in vitro de helmintosis para evaluar el efecto de factores antiangiogénicos (endostatina).

4.- Utilizar modelos experimentales de infección de estrongioloidosis por S. venezuelensis y esquistosomosis por S. mansoni para valorar el efecto de factores anti- 
angiogénicos en el desarrollo de la infección, estudiando los mecanismos que puedan estar involucrados.

5.- Analizar la producción de factores angiogénicos en sueros de pacientes con diagnóstico de helmintosis importadas.

Tanto los materiales y métodos como los resultados y discusión de los experimentos realizados en esta Tesis Doctoral se han dividio en tres apartados que corresponden a los estudios realizados sobre angiogénesis y tres de la pricipales helmintosis: triquinelosis, estrongiloidosis y esquistosomosis.

En el primer trabajo se estudia la expresión diferencial de factores angiogénicos en macrófagos estimulados con antígenos de especies encapsuladas y no encapsuladas de Trichinella. Este trabajo ha sido publicado en Experimental Parasitology 2009, 123: 347353.

Los objetivos, metodología, resultados, discusión y conclusiones principales se exponen a continuación:

Introducción: El estadio larvario de T. spiralis se introduce en la célula del músculo estriado formando la célula nodriza. Se detectó factor de crecimiento del endotelio vascular (VEGF) en en el área que rodea las células nodrizas. Sin embargo, no se dispone de datos sobre los antígenos implicados, el papel de otros factores angiogénicos o la relación de la angiogénesis con el óxido nítrico $(\mathrm{ON})$.

Metodología: Se usaron cultivos celulares de macrófagos alveolares para estudiar el efecto de diferentes antígenos de larva1 de $T$. spiralis (especie encapsulada) y $T$. pseudospiralis (especie no encapsulada) sobre la expresión de VEGF y factor básico de crecimiento de fibroblastos (FGF2). Además, se investiga la relación entre la producción de ON y los mediadores angiogénicos. 
Resultados: Los resultados muestran que especies encapsuladas y no encapsuladas de Trichinella son diferentes en su capacidad de estimular la expresión de VEGF y FGF2 por los macrófagos alveolares. T. spiralis estimula la producción de factores angiogénicos mientras que $T$. pseudospiralis no es capaz de estimular estas células. Por último, no hay ninguna relación entre los factores angiogénicos y la producción de ON por el antígeno de T. spiralis.

Discusión: Las especies encapsuladas se caracterizan por el depósito de colágeno y otros componentes de la matriz extracelular alrededor de las larvas de Trichinella. Un proceso clave asociado a la fibrogénesis es la angiogénesis. De hecho, los datos experimentales sugieren que la hipoxia en relación con el VEGF puede estimular la proliferación de la síntesis de colágeno tipo 1 en miofibroblastos. Nuestros resultados indican que los macrófagos son capaces de producir y liberar no sólo VEGF, sino también FGF2 en respuesta a los antígenos de las especies encapsuladas como T. spiralis en una manera dosis-dependiente. La expresión génica del VEGF se determinó mediante RT-PCR y expresión de la proteína medida por ELISA. Sin embargo, las especies no encapsuladas como T. pseudospiralis no fueron capaces de inducir la expresión de estos factores angiogénicos. La larva penetra en la célula muscular, crece en ella y destruye las miofibrillas. Las células satélite que rodean a la fibra muscular sufren cambios morfológicos transformándose en células nodrizas. Previamente se ha demostrado que las células nodriza son capaces de producir VEGF durante la infección por T. spiralis. En este trabajo se demuestra que las células inflamatorias que rodean a la fibra del músculo lesionado contribuyen a la producción de factores angiogénicos. Probablemente, ambos tipos de células están implicadas en el desarrollo de la cápsula de esta especie. Estudios previos realizados por nuestro grupo han demostrado que antígenos de especies encapsuladas y no encapsuladas de Trichinella fueron capaces de estimular la producción de óxido nítrico. 
Como este mediador inflamatorio es un factor de inducción para la producción de VEGF, se evaluó si la inhibición de la óxido nítrico sintasa inducible, mediante el uso de inhibidores específicos como L-NAME y L-canavanina, modifican el efecto ejercido por los antígenos de Trichinella en la producción de factores angiogénicos. Este estudio demuestra que el efecto de los antígenos de T. spiralis no depende de óxido nítrico. En resumen, los antígenos de las especies encapsuladas de Trichinella estimulan directamente la producción de factores angiogénicos que pueden contribuir a la patogenia desarrollada en esta infección.

En el segundo trabajo se estudia el papel de los factores angiogénicos en la infección aguda experimental desencadenada por Strongyloides venezuelensis. Este trabajo ha sido aceptado para publicación en Parasite Immunology el día 11 de Enero de 2010.

Los objetivos, metodología, resultados, discusión y conclusiones principales se exponen a continuación:

Introducción: Este estudio tiene como objetivo investigar el papel de los factores angiogénicos en la patogénesis de la estrongiloidosis experimental.

Metodología: Dos enfoques complementarios fueron utilizados: En primer lugar, se trataron ratones CD1 con endostatina, un inhibidor de la angiogénesis, y posteriormente fueron infectados con Strongyloides venezuelensis. Además, se estudiaron los mecanismos implicados en este proceso. En segundo lugar, se investigó el efecto de los antígenos responsables de la estimulación de los factores angiogénicos (VEGF y FGF2) por macrófagos alveolares y los mecanismos implicados en su producción. Los macrófagos alveolares se obtuvieron por lavado broncoalveolar y se incubaron a diferentes concentraciones de antígenos somáticos y de excreción de secreción de S. venezuelensis. Además, los niveles de ARNm de VEGF y FGF2 fueron detectados por RT-PCR.

Resultados: Los ratones tratados con endostatina mostraron disminución significativa de huevos por gramo de heces y del número de larvas obtenidas del pulmón. Los 
mecanismos implicados en esta disminución pueden ser tanto directos, con disminución de los factores angiogénicos, como indirectos con aumento de eosinófilos. Además se ha comprobado que únicamente los antígenos somáticos de las larvas 3 estimulan VEGF y FGF2. Por último se ha observado la relación existente entre los factores de la angiogénesis y el óxido nítrico analizada mediante el uso de inhibidores de la óxido nítrico sintasa inducible.

Discusión: La estrongiloidosis es una nematodosis de distribución cosmopolita que es especialmente relevante en individuos inmunocomprometidos, preferentemente en personas que reciben terapia con corticoides y en las regiones tropicales y subtropicales. Los mecanismos patogénicos en esta enfermedad son bastante desconocidos. Algunos autores han propuesto para el estudio de estos mecanismos modelos experimentales similares a S. stercoralis, utilizando especies de Strongyloides como $S$ ratti y S. venezuelensis. El pulmón y las células que intervienen en su defensa, macrófagos alveolares, constituyen un primer elemento de estudio en la infección producida por este nematodo. Los trabajos realizados por nuestro grupo de investigación han puesto de manifiesto la producción de ON por macrófagos alveolares estimulados con antígenos larvarios de S. venezuelensis, demostrando la participación de este mediador inflamatorio en la estrongiloidosis experimental. Sin embargo, faltan estudios sobre el papel de otros mediadores inflamatorios y su posible relación con $\mathrm{ON}$ en la estrongiloidosis. La angiogénesis es un proceso complejo que conduce a la neovascularización generada a partir de los vasos sanguíneos preexistentes. Se asocia con la inflamación, la cicatrización de heridas, el crecimiento tumoral y la metástasis. La generación de nuevos vasos sanguíneos está regulada por las moléculas proangiogénicas y antiangiogénicas. Los factores de crecimiento vascular endotelial (VEGF) y factores de crecimiento de fibroblastos (FGF) son los principales mediadores de la angiogénesis en el desarrollo y progresión de muchas enfermedades. Existen poco trabajos 
donde se estudia la relación entre factores angiogénicos y helmintosis. Una correlación positiva se observó entre el VEGF en plasma y la aparición de hidrocele en personas infectadas con $W$. bancrofti. Además, se encontró VEGF como factor protector en la malaria cerebral. En este trabajo nos planteamos evaluar el papel de factores angiogénicos en la estrongiloidosis experimental. Para ello estudiamos: (i) La modulación de la infección utilizando inhibidores específicos de la angiogénesis como la endostatina. (ii) La inducción de VEGF y FGF2 en macrófagos alveolares estimulados con antígenos derivados de distintas fases del ciclo biológico de S. venezuelensis y (iii) la relación entre estos factores y la producción de ON. La endostatina es una molécula de $20 \mathrm{kDa}$ que pertenece al fragmento carbóxilo terminal del colágeno XVIII que cuando se añade de forma exógena inhibe la angiogénesis. En este estudio se demuestra que los factores angiogénicos tienen un papel relevante en la primoinfección por S. venezuelensis. El uso de endostatina disminuye tanto el número de larvas en el pulmón como la producción de huevos en heces. ¿Esto es debido a efectos directos sobre el parásito o indirectos vía hospedador? Para responder a esta cuestión, realizamos estudios in vitro sobre efecto de la endostatina sobre la supervivencia o mortalidad de los parásitos. Los resultados demuestran que la endostatina no tienen efecto directo sobre el parásito. El efecto indirecto sobre el hospedador puede ser atribuido a dos mecanismos complementarios. En primer lugar disminuyendo directamente la producción de factores angiogénicos, dato que se observa en nuestro estudio mediante la reducción de la expresión de VEGF y FGF2 en el pulmón y el intestino. En segundo lugar, algunos autores han observado que los eosinófilos tienen la posibilidad de participar en la angiogénesis mediante la inducción de la producción de VEGF. Por otra parte, el VEGF se ha asociado con la alteración de la barrera hematoencefálica en pacientes con meningitis eosinofílica causada por Angyostrongylus cantonensis. Nuestros datos indican que los ratones infectados con S. venezuelensis y tratados con endostatina tienen menor número de eosinófilos. Los macrófagos son conocidos por producir varios factores angiogénicos, incluyendo el potente 
factor de crecimiento del endotelio vascular (VEGF), factor de crecimiento de la placenta (PlGF), factor básico de crecimiento de fibroblastos (FGF2), factor de crecimiento transformante $\beta$ (TGF- $\beta$ ), interleucina-8 (IL-8) y una gran cantidad de citocinas pro-

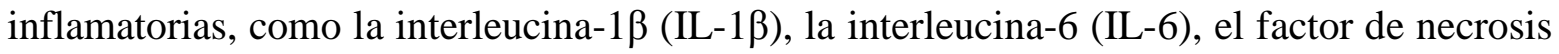
tumoral alfa (TNF- $\alpha$ ) y el factor estimulante de colonias de granulocitos y monocitos (GMCSF). Los estudios realizados por nuestro grupo han demostrado la producción de VEGF y FGF2 en macrófagos alveolares estimulados con antígenos larvarios de T. spiralis. En este trabajo nos hemos propuesto estudiar los antígenos de S. venezuelensis responsables de la inducción de factores angiogénicos. Para ello utilizamos antígenos somáticos y excretores secretores de larva y hembras de S. venezuelensis. Solamente el antígeno somático de larva III de S. venezuelensis estimula la producción de VEGF y FGF2 en macrófagos alveolares y estos factores están asociados con la infección originada por este nematodo. Futuros estudios mediante análisis proteómico irán encaminados a dilucidar las moléculas procedentes del antígenos somático larvario responsables de este efecto. Estas podrán servir como dianas terapéuticas para diseñar vacunas frente a Strongyloides. El óxido nírico producido por los macrófagos activados y las células endoteliales es una molécula de señalización intracelular e intercelular generados a partir de L-arginina, que podría estar relacionado con las etapas de la angiogénesis. En este trabajo estudiamos la posible relación entre estos mediadores tras la estimulación macrofágica de los antígenos somáticos larvarios de S. venezuelensis. Utilizamos inhibidores de la iNOS como L-NAME y L-canavanina y hemos podido comprobar la asociación entre la producción de ON y la producción de factores angiogénicos, ya que estos inhibidores son también capaces de inhibir la expresión de los factores angiogénicos. Esta relación no se observó en la inducción de VEGF y FGF2 por antígenos larvarios de T. spiralis. 
En el tercer trabajo se estudia la expresión de los factores de angiogénicos en la esquistosomosis humana y experimental. Este trabajo ha sido enviado para publicación a Plos Neglected Tropical Diseases el día 18 de Enero de 2010.

Los objetivos, metodología, resultados, discusión y conclusiones principales se exponen a continuación:

Introducción: La angiogénesis, el proceso de formación de nuevos vasos sanguíneos, tiene un papel importante en diversos procesos, incluyendo el cáncer y la inflamación. La esquistosomosis es una helmintosis que afecta a más de 200 millones de personas en el mundo. Los trabajos anteriores han demostrado que los antígenos solubles de Schistosoma mansoni inducen la expresión del factor de crecimiento del endotelio vascular (VEGF) en células endoteliales humanas. Los objetivos del estudio son: (i) Estudiar la presencia de VEGF en suero de pacientes diagnosticados de esquistosomosis y de otras helmintosis. (ii) Evaluar el efecto de endostatina en modelo experimental murino infectado con S. mansoni. (iii) Detectar VEGF y factor de crecimiento de fibroblastos (FGF2) en macrófagos alveolares estimulados con antígenos de cercaria y adultos de $S$. mansoni.

Metodología: Se han utilizado sueros de pacientes sanos y con diagnóstico parasitológico de esquistosomosis y otras helmintosis, para detectar VEGF mediante un técnica de ELISA comercial. Además se han empleado ratones CD1 divididos en tres grupos: (i) Sanos. (ii) Ratones infectados con 150 cercarias de S. mansoni. (iii) Ratones infectados y tratados con endostatina. Las magnitudes analizadas fueron: datos parasitológicos, hematológicos, detección de $\operatorname{IgG}$, IgG1 e IgG2a específicas mediante ELISA y expresión de VEGF y FGF2 en hígado e intestino mediante RT-PCR. Por último se ha evaluado en macrófagos alveolares la expresión de VEGF y FGF2 estimulados con diferentes antígenos de S. mansoni mediante RT-PCR. 
Resultados: En primer lugar, los pacientes diagnosticados con esquistosomosis mostraron diferencias significativas en la detección de VEGF respecto a los demás grupos estudiados. Sin embargo, no hubo diferencias entre los pacientes infectados por S. mansoni y S. haematobium. En segundo lugar, los ratones infectados y tratados con endostatina mostraron diferencias significativas en la disminución del número de huevos presentes en hígado y en la detección de anticuerpos IgG2a específicos. Por último, solo se observó expresión de VEGF y FGF2 en macrófagos alveolares estimulados con 50 $\mu \mathrm{g} / \mathrm{ml}$ de antígeno de cercaria de S. mansoni.

Discusión: Las principales helmintosis que afectan a la población humana son geohelmintosis, esquistosomosis y filariosis. También son estas helmintosis las detectadas en pacientes inmigrantes asintomáticos con eosinofilia absoluta o relativa. En este trabajo nosotros evaluamos VEGF en sueros de pacientes diagnósticados con una helmintosis. Para ello seleccionamos inmigrantes subsaharianos con eosinofilia donde la realización de un estudio detallado mostraba la presencia de un solo helminto, no de coinfecciones. Encontramos que los pacientes diagnosticados de esquistosomosis tenían niveles significativos de VEGF en suero respeto al grupo de pacientes sanos. Estos resultados son similares a los observados por otros autores en infecciones por $S$. mansoni. También pudimos comprobar que no había diferencias significativas entre los valores de VEGF encontrados en esquistosomosis por S. mansoni y por S. haematobium. La angiogénesis juega un papel fundamental en muchos procesos fisiológicos y patológicos, incluyendo el desarrollo de la fibrosis hepática. En la cirrosis, se reducen los niveles de VEGF en suero. Sin embargo, se detectaron altos niveles de VEGF en el suero de pacientes con esquistosomosis, aunque otros autores encontarron valores diferentes de VEGF en las distintas fases clínicas de la esquistosomosis. Además hemos comprobado que los eosinófilos no son las únicas células implicadas en la expresión de VEGF en humanos ya 
que no hay asociación entre el número de eosinófilos y los valores de VEGF. En la segunda parte de nuestro trabajo, nosotros estudiamos en un modelo experimental de S. mansoni, los efectos que se producían tras la inhibición por factores anti-angiogénicos. Para ello utilizamos endostatina como inhibidor específico de la angiogénesis. Ratones infectados con S. mansoni y tratados con endostatina no presentaban reducción significativa de vermes adultos. Sin embargo, había reducciones significativas en el número de huevos en hígado, así como en el número de granulomas hepáticos. Esto indica que la inhibición de la angiogénesis induce una disminución de las lesiones hepáticas desencadenantes de la formación del granuloma y por tanto de la fibrosis hepática subsiguiente. A continuación estudiamos los posibles mecanismos implicados en la reducción de la lesión. En primer lugar analizamos datos de recuento de serie roja, blanca y plaquetas. No observamos diferencias significativas en ninguno de los datos analizados, específicamente en la reducción del número de eosinófilos. Estos resultados obtenidos en el modelo experimental concuerdan con lo observado en sueros humanos. Este dato es opuesto al hallado por nuestro grupo cuando analizamos la relación angiogénesis y estrongiloidosis. En segundo lugar pudimos demostrar la disminución de la expresión de VEGF y FGF2 en hígado. Este dato demuestra la inhibición efectiva realizada por endostatina. En tercer lugar analizamos la respuesta inmunitaria producida entre los grupos de estudio. Encontramos disminución significativa en la detección de IgG2a específicas. Esta reducción está relacionada con la disminución de respuestas Th1 efectoras en los animales tratados con endostatina, en los cuales existe reducción en el número de huevos en hígado y de granulomas observados. Estos resultados coinciden con las observaciones de otros autores en que la esquistosomosis grave se asocia con elevación persistente de citocinas pro-inflamatorias tipo Th1, mientras que la afección más leve está presente cuando aumentan las citocinas tipo Th2. Por otra parte, el cambio hacia la producción de citocinas tipo Th1 producidas por una población estable de células $\mathrm{CD}^{+}$se correlaciona con la exacerbación grave de la inmunopatología de 
la esquistosomosis. El último objetivo de nuestro estudio fue identificar los antígenos de S. mansoni que participan en la expresión de VEGF y FGF2 producido por los macrófagos alveolares. Usamos antígenos de cercarias y de vermes adultos de S. mansoni. Nuestros resultados han mostrado que los antígenos de cercaria eran capaces de estimular la producción de factores angiogénicos en macrófagos alveolares. Estos resultados y los datos obtenidos por otros autores muestran el papel de la angiogénesis en la esquistosomosis y su participación en la reacción granulomatosa asociada a la lesión. En resumen, este estudio pone de manifiesto el papel de la angiogénesis en la patogenia de la esquistosomosis debido a tres aspectos: (i) La detección de VEGF en pacientes con diagnóstico de esquistosomosis. (ii) La reducción de huevos y la formación de granulomas en el hígado de ratones tratados con endostatina con predominio de respuestas tipo Th1. (iii) El aumento de expresión de VEGF y FGF2 tras la estimulación de macrófagos alveolares por antígenos de cercarias de S. mansoni.

Finalmente las conclusiones de esta tesis doctoral son son:

1.- Los antígenos de la especie encapsulada Trichinella spiralis son capaces de estimular de forma dosis-dependiente los factores angiogénicos como VEGF y FGF2 por macrófagos alveolares de rata.

2.- La angiogénesis desempeña un papel relevante en la primoinfección por Strongyloides venezuelensis, ya que su inhibición mediante el empleo de endostatina produce disminución de las magnitudes de infección.

3.- La endostatina reduce la infección de Strongyloides venezuelensis no por acción directa sobre el parásito sino a través de efectos indirectos como la disminución de la producción de factores angiogénicos por el hospedador o la reducción de la respuesta eosinofílica. 
4.- Los antígenos somáticos larvarios de Strongyloides venezuelensis son los responsables de la inducción de factores angiogénicos y su modulación está relacionada con la generación de óxido nítrico.

5.- En pacientes con esquistosomosis existe un aumento en los niveles séricos de VEGF con diferencias significativas con respecto a otras helmintosis.

6.- La inhibición de la angiogénesis mediante endostatina en la esquistosomosis experimental murina induce una disminución en el número de huevos en hígado, así como en la presencia de granulomas y de fibrosis hepática.

7.- Los antígenos de cercarias de S. mansoni inducen la expresión de factores angiogénicos en macrófagos alveolares de rata. 


\section{Methodological appendix}




\subsection{Collection of rat alveolar macrophages samples for measurement of nitric oxide.}

Alveolar macrophages from male Wistar rat were obtained by bronchoalveolar lavage Espinoza et al., (2002) and Nurkiewicz et al., (2004). Lungs were lavaged with aliquots of 5 $\mathrm{ml}$ of sterile PBS with sterile cannula for collection of BAL fluid as order that come below. Male Wistar rats are used in all experiments and alveolar macrophages were obtained by bronchoalveolar lavage technique (BAL).

\section{Materials:}

- Male Wistar rat weighting 250-300 g.

- Sodium pentobarbital ( $\geq 100 \mathrm{mg} / \mathrm{kg}$, i.p.).

- Teflon catheter (VYCON Code 123.06).

- Phosphate-Buffered Saline (PBS 1x sterile pH 7.4)

- Ethanol (141086, Panreac).

- Thoma Pipette.

- Microspirator (258 00, Brand).

- Liquid of Turk (251390, Panreac).

- Neubauer.

Procedure:

- Rats were euthanized with an intraperitoneal injection (ip) of sodium pentobarbital $\geq 100 \mathrm{mg} / \mathrm{kg}$ body weight.

- A tracheal cannula (teflon catheter) was inserted.

- BAL was performed through the cannula using ice-cold PBS (each time, to inject $5 \mathrm{ml}$ of PBS sterile with $\mathrm{pH} 7.4$ through the cannula and collection BAL with a syringe $5 \mathrm{ml}$ ) and repeat 10 to 15 times, and collect BAL in a $50 \mathrm{ml}$ tube.

- Centrifuge BAL at $500 \mathrm{~g}$ for $10 \mathrm{~min}$ at $4^{\circ} \mathrm{C}$ and remove the supernatant.

- Macrophage cells resuspended cells in $1 \mathrm{ml}$ of Dulbecco's medium.

- The isolation of acellular BAL fluid and BAL cells were counted as described Porter et al., 2004). 


\subsection{Rat alveolar macrophages cultures}

Rat alveolar macrophages were exposed to different concentrations of extracts of S. venezuelensis, using the basal cells (macrophages) as a negative control and macrophages stimulated with LPS as a positive control. The procedure is based on the technique described by Evans et al. (2002a) and Andrade et al. (2005a).

\section{Materials:}

- Dulbecco's modified Eagle's medium (DMEM, D-0819 Sigma).

- Fetal bovine serum (12003C, Sigma).

- Glutamine (G-5792, Sigma).

- Complete medium (10\% fetal bovine serum, $2 \mathrm{mM}$ of glutamine, $100 \mathrm{U} / 100 \mu \mathrm{g} / \mathrm{ml}$ penicillin-streptomycin and $44 \mathrm{ml}$ of DMEM).

- Peniciline y estreptomicine (P-4333, Sigma-Aldrich, Inc., San Luis, EE.UU.).

- Culture Plates (Costar, Cambridge, MA).

- Lipopolysaccharide (LPS) (L-2880, Sigma)

- Polymixin B (PMB P-4932, Sigma)

- L-NAME: N $\omega$-nitro-L-arginin methyl ester hydrochloride (N-5751, Sigma)

- L-canavanine (C-9758, Sigma)

- Trypsin (T9935, Sigma)

- Incubator of $\mathrm{CO}_{2}($ Galaxy St, BIOTECH)

\section{Procedure:}

- Macrophages $\left(1 \times 10^{6} /\right.$ well $)$ were washed with DMEM two times and then were placed on culture plates.

- Incubate $2 \mathrm{~h}$ at $37^{\circ} \mathrm{C}$ in $5 \% \mathrm{CO}_{2}$ to adhere cells on the plastic bottom of the culture plates.

- Remove non-adhering cells by gentle washing with complete medium and discard it and add $1 \mathrm{ml}$ of fresh complete medium for further cell culture.

- Incubated adherent alveolar macrophages alone (as a negative control, Ø), with lipopolysaccharide (LPS) as a positive control with several concentrations, ranging from 0.1 to $50 \mu \mathrm{g}$ protein $/ \mathrm{ml}$, with different antigens.

- Incubate for $18 \mathrm{~h}$ at $37^{\circ} \mathrm{C}$ in $5 \% \mathrm{CO}_{2}$, then culture supernatants collected and centrifuged at $500 \mathrm{~g}$ for $10 \mathrm{~min}$.

- Collect supernatants after $18 \mathrm{~h}$, centrifuge at $500 \mathrm{~g}$ for $10 \mathrm{~min}$ and store at $-80^{\circ} \mathrm{C}$ as an archival material.

- Recovered macrophages and stored at $-80^{\circ} \mathrm{C}$. 


\subsection{Determination of viability of rat alveolar macrophages}

The cell viability was assessed by mitochondrial reduction of MTT after removing the supernatant according to Kiemer and Vollmar (1997). Cell viability, should be higher than $87.5 \%$ in all cases.

\section{Materials:}

- Spectrophotometer (Easy Reader EAR 400FT).

- MTT: (3-[4, 5-dimethylthiazol-2-yl]-2, 5-diphenyl-tetrazolium bromide; M2003, Sigma).

- Dimethyl sulfoxide (DMSO, 07-4872, Sigma)

- 96wells Plates

\section{Procedure:}

- Add $200 \mu \mathrm{l}$ of MTT $(0.5 \mathrm{mg} / \mathrm{ml})$ in each well and incubate alveolar macrophages for 1 hr at $37^{\circ} \mathrm{C}$

- Remove MTT completely from all plate and add $200 \mu$ of DMSO or 50\%ethyl alcohol with 50\%DMSO

- Determine optical density immediately at $550 \mathrm{~nm}$ in a Easy reader EAR 400 FT photometer.

- Following the measure viability of cells, alveolar macrophages were collected and store them at $-80^{\circ} \mathrm{C}$.

\subsection{Griess assay for measure of nitrites.}

To measure nitric oxide in the cell culture supernatant was used Griess technique that is based on the property have nitrites react with primary aromatic amino acid medium, resulting diazonium compounds that give color pink (Green et al., 1982; Campisi et al., 2002). Supernatant of macrophage culture are used for nitrite determination according to Andrade et al. (2007).

\section{Materials:}

- Solution A: 1\% sulfanilamide, 0.12M (S-9251, Sigma) in H3PO4 $0.36 \mathrm{M}$

- Solution B: dihidrocloruro of N-(1-naftil) etilendiamine 7.7mM (N-5889, Sigma) in H3PO4 $0.36 \mathrm{M}$

- Stock solution: 1 M of NaNO2 (S-2252-500G, Sigma).

- Spectrophotometer (Easy Reader EAR 400FT)

\section{Procedure:}

- Make different dilution of medium that we want to determine nitrites from $1 \mu \mathrm{M}$ to $100 \mu \mathrm{M}$.

- Prepare the Griess reagent, solution A and solution B, mix them and prepare with the equal portion immediately before their utilization. 
- Add $100 \mu \mathrm{l}$ to each well of blank (only complete medium), patron and sample triplicate in 96 wells plaque.

- Add $50 \mu \mathrm{l}$ of reagent of Griess for each well; incubate $15 \mathrm{~min}$ in bench top $\left(20-30^{\circ} \mathrm{C}\right)$.

- Measured the absorbance of the azochromophore at $550 \mathrm{~nm}$.

\subsection{Extraction of RNA from rat alveolar macrophages}

For the RNA extraction from macrophages was used the commercial kit RNeasy Mini Kit (Qiagen). This kit is used for purification of total RNA from animal cells and animal tissue and for cleanup of RNA from crude RNA prep and enzymatic reactions.

\section{Materials:}

- RNeasy Mini Kit (Code, Qiagen)

- Qiashreder (Code, Qiagen)

- RNase-Free DNase Set (Code, Qiagen)

\section{Procedure:}

- Determine the number of cells (macrophages, between $10^{6}-10^{7}$ cells) and centrifuge them for $5 \mathrm{~min}$ at $300 \times \mathrm{g}$. Then carefully remove all supernatant by aspiration and proceed to step 2.

- Add appropriate of Buffer RLT (350-600 $\mu \mathrm{l})$ for disruption the cells. Vortex or pipet them to mix and go to the third step.

- Homogenize the lysate for 2 min centrifuge at full speed using Qiashreder spin column.

- Add 1 volume of $70 \%$ ethanol (the same volume of lysate) to homogenized lysate and mix well by pipeting.

- Transfer $700 \mu \mathrm{l}$ of the sample to an RNeasy spin column placed in a $2 \mathrm{ml}$ collection tube. Then gently closed the lid and centrifuge them for $15 \mathrm{~s}$ at $8000 \mathrm{~g}$ and after that discard the flow-through.

- Add $350 \mu 1$ of RW1 to the RNeasy column, closed the lid gently and centrifuge 15 seconds at $8000 \mathrm{~g}$ (for washing the column membrane). Throw away the flow-through.

- Add $80 \mu \mathrm{l}$ of DNase 1 incubation mix (add $10 \mu$ l DNase enzymes to $70 \mu \mathrm{l}$ RDD buffer and mix them gently) to the spin column membrane and place on the bench top for 15 $\min$ at $20-30^{\circ} \mathrm{C}$.

- Add $350 \mu \mathrm{l}$ RW1 to the spin column, close the lid gently and centrifuge for 15 seconds at $8000 \mathrm{~g}$. Then discard the flow-through.

- Add $500 \mu \mathrm{l}$ of RPE buffer to the column, close the lid gently and centrifuge at $8000 \mathrm{~g}$ for 15 seconds (For washing the column membrane), then throw away the flow-through.

- Add again $500 \mu \mathrm{l}$ of RPE buffer to the column, close the lid slowly and centrifuge them for 2 min at $8000 \mathrm{~g}$ to wash the column membrane.

- Place the spin column in a new $2 \mathrm{ml}$ collection tube and discard the old collection tube with the flow-through. Close the lid gently, and centrifuge at full speed for $1 \mathrm{~min}$.

- Finally, put the spin column in a new 1.5 collection tube and add 30-50 $\mu 1$ RNase-Free water directly to the column membrane. Close the lid slowly and centrifuge at $1 \mathrm{~min}$ at $8000 \times \mathrm{x}$ to elute the RNA.

- Store RNA at $-80^{\circ} \mathrm{C}$. 


\subsection{RNA extraction from experimental animal tissue}

It is essential to use the correct amount of stating material in order to obtain optimal RNA yield and purity from liver, intestine and lung. A maximum amount of $30 \mathrm{mg}$ fresh or frozen tissue or 15-20 mg RNA later stabilized tissue.

\section{Materials:}

- RNeasy Mini Kit (Qiagen)

- Qiashreder (Qiagen)

- RNase-Free DNase Set (Qiagen)

- Mortar and pestle

\section{Procedure:}

- Weight $10-30 \mathrm{mg}$ of tissue and cut it into slices less than $0.5 \mathrm{~cm}$ thick as quickly as possible. Then the tissue pieces completely submerge in the RNAlater (Stabilization reagent). For archival storage at $-20^{\circ} \mathrm{C}$, first incubate the tissue overnight in the RNAlater at $2-8^{\circ} \mathrm{C}$. Then remove the tissue from the reagent, and transfer it to $-20^{\circ} \mathrm{C}$ for storage.

- Place the weighed (fresh, frozen, or RNAlater stabilized) tissue in liquid nitrogen, and grind thoroughly with a mortar and pestle. Decant tissue powder and liquid nitrogen into an RNase-Free, liquid-nitrogen-cooled, $2 \mathrm{ml}$ microcentrifuge tube. Allow the nitrogen liquid to evaporate but don't allow thawing the tissue.

- Add the appropriate volume of RLT buffer, and pipet the lysate directly into a QIAshreder spin column placed into a $2 \mathrm{ml}$ collection tube and centrifuge for $2 \mathrm{~min}$ at full speed.

- Centrifuge the lysate for $3 \mathrm{~min}$ at full speed and then carefully removed the supernatant by pipeting, and transfer it to a new microcentrifuge tube. We use only this supernatant (lysate) in subsequent steps.

- Add 1 volume of 70\% ethanol (the same volume of lysate) to homogenized lysate and mix immediately by pipeting (don't centrifuge it).

- Transfer $700 \mu \mathrm{l}$ of the sample to an RNeasy spin column placed in a $2 \mathrm{ml}$ collection tube. Then gently closed the lid and centrifuge them for $15 \mathrm{~s}$ at $8000 \mathrm{~g}$ and after that discard the flow-through.

- Add $350 \mu$ l of RW1 to the RNeasy column, closed the lid gently and centrifuge 15 seconds at $8000 \mathrm{~g}$ (for washing the column membrane). Throw away the flow-through.

- Add $80 \mu 1$ of DNase 1 incubation mix (add $10 \mu$ l DNase enzymes to $70 \mu 1$ RDD buffer and mix them gently) to the spin column membrane and place on the bench top for 15 $\min$ at $20-30^{\circ} \mathrm{C}$.

- Add $350 \mu 1 \mathrm{RW} 1$ to the spin column, close the lid gently and centrifuge for 15 seconds at $8000 \mathrm{~g}$. Then discard the flow-through.

- Add $500 \mu$ of RPE buffer to the column, close the lid gently and centrifuge at $8000 \mathrm{~g}$ for 15 seconds (For washing the column membrane), then throw away the flow-through.

- Add again $500 \mu 1$ of RPE buffer to the column, close the lid slowly and centrifuge them for $2 \mathrm{~min}$ at $8000 \mathrm{~g}$ to wash the column membrane

- Place the RNeasy spin column in a new $2 \mathrm{ml}$ collection tube and discard the old collection tube with the flow-through. Close the lid gently, and centrifuge at full speed for $1 \mathrm{~min}$. 
- Then, place the RNeasy spin column in a new 1.5 collection tube. Add 30-50 $\mu$ l RNaseFree water (Depend the RNA yield) directly to the column membrane. Close the lid slowly and centrifuge for $1 \mathrm{~min}$ at $8000 \mathrm{~g}$ to elute the RNA.

- If the expected RNA yield is $30 \mu \mathrm{g}$, repeat the step 13 using another 30-50 $\mu 1$ RNase free water, or using elute from step 13 (If we want high RNA concentration).

- Store RNA at $-80^{\circ} \mathrm{C}$ immediately and it is essential that working with RNA fast because it's very instable and degrade rapidly.

\subsection{RT-PCR for detection of VEGF and FGF2 in alveolar macrophages}

It was performed with RT-PCR kit (11483188001, Roche) by RNA extracted from rat alveolar macrophages. It is the first complementary DNA strand in two steps; synthesis at $42^{\circ} \mathrm{C}$ and denaturation at $95^{\circ} \mathrm{C}$ (Andrade et al., 2005).

\section{Materials:}

- Sterile vials of $0.5 \mathrm{ml}$.

- Thermal cycler (Perkin Elmer Instrument, Norwalk, USA).

- Oligonucleotides OligodT (27-7858, Pharmacia Biotech).

- Mastermix (cDNA).

- Nuclease-free water (DEPC).

Table 5.1: Reagent and amount and final concentration per sample for RT-PCR.

\begin{tabular}{lll}
\hline Reagent & Volume.1 sample & Final conc. 1 sample \\
\hline $10 \times$ Reaction Buffer $_{25 \mathrm{~m} \mathrm{MCl}_{2}}$ & $2.0 \mu \mathrm{l}$ & $1 \times$ \\
Deoxynucleotide Mix & $4.0 \mu \mathrm{l}$ & $5 \mathrm{mM}$ \\
Oligo-p (dT)15 & $2.0 \mu \mathrm{l}$ & $1 \mathrm{mM}$ \\
RNase Inhibitor & $2.0 \mu \mathrm{l}$ & $0.04 \mathrm{~A} 260$ units $(1.6 \mu \mathrm{g})$ \\
AMW Reverse Transcriptase & $0.8 \mu \mathrm{l}$ & 50 units \\
Sterile water & variable & $\geq 20$ units \\
RNA sample & variable & - \\
\hline Total & $\mathbf{2 0 \mu l}$ & - \\
\hline
\end{tabular}

Procedure:

- The amount of RNA sample add to sample reactions (The amount of RNA that added to sample reaction is depends on the nature of the RNA used and on the intended application; normally, $\leq 1 \mu \mathrm{g}$ of total RNA, 50-100 ng of poly [A] + RNA, or 6 fg-1 $1 \mu \mathrm{g}$ of a single, purified RNA species [e.g., the control Neo pa RNA] is required according Table 5.1.

- Briefly vortex and centrifuge the mixture to collect the sample at the bottom of the microfuge tube.- Incubate the reaction at $+25^{\circ} \mathrm{C}$ for $10 \mathrm{~min}$; during the first incubation, primer anneals to the RNA template. 
- Then incubate the reaction at $+42^{\circ} \mathrm{C}$ for $1 \mathrm{hr}$; during the second incubation, The RNA is subsequently reverse transcribed, resulting in cDNA synthesis.

- The AMW Reverse Transcriptase denatured by Incubation the reaction at $99^{\circ} \mathrm{C}$ for 5 minutes.

- Cool the reaction at $4^{\circ} \mathrm{C}$ for 5 minutes.

- At this point, the reaction tube maybe stored at +2 to $8^{\circ} \mathrm{C}$ for $1-2 \mathrm{~h}$ or at -15 to $-25^{\circ} \mathrm{C}$ for longer periods.

\subsection{Chain reaction polymerase (PCR).}

VEGF is determined in rat alveolar macrophages after cultivation and determination of viability. Total RNA was extracted from macrophages following the instructions of the commercial kit RNeasy Mini Kit (Qiagen GmbH, Hilden Germany).Then a total $1 \mu \mathrm{g}$ RNA was used as template for the first-strand DNA synthesis (Roche 1483188). The VEGF insert amplification was performed with primers described by Yang et al. (2004) and FGF-2 insert amplification was performed with primers described by Jyo-Oshiro et al. (1999). Primer sequence for VEGF was: sense, 5'-CTGCTCTCTTGGGTGCACTGG-3' and anti-sense, 5'CACCGCCTTGGCTTGTCACAT-3’. Primer sequence for FGF2 was: sense, 5'GCCGGCAGCATCACTTCGCT-3' and anti-sense, 5'CTGTCCAGGCCCCGTTTTGG3'. Glyceraldehydes-3-phosphate dehydrogenase (GAPDH) was used as an internal control and GAPDH sense, 5'-GGTCGGTGTGAACGGATTTG-3' and GAPDH anti-sense, 5'GTGAGCCCCAGCCTTCTCCAT -3'. To reveal the reaction, the PCR product was separated in an agarose gel and ethidium bromide.

\section{Materials:}

- 10X Buffer (Promega M1906).

- $\mathrm{MgCl}_{2}(25 \mathrm{mM})$.

- Deoxynucleotide mix 1 mM (Boehringer Mannheim, 1093 088).

- Taq DNA polymerase (Promega, M1665).

- Water DEPC.

- Primers: VEGF 20 mM, FGF-2 20mM and GAPDH 20 mM.

- Thermal cycler.

- Template cDNA.

\section{Procedure:}

- For each reaction to a container with $20 \mu \mathrm{l}$ in each eppendorf $2 \mu \mathrm{l}$ of buffer, $3 \mathrm{mM}$ of $\mathrm{MgCl}_{2} 50 \mathrm{mM}, 2 \mathrm{mM}$ of deoxynucleotide mix1 $\mathrm{mM}$ and $0.125 \mu \mathrm{l}$ of Taq DNA polymerase.

- Add to each reaction $1 \mathrm{mM}$ of each primer in case of VEGF and GAPDH and $0.5 \mathrm{mM}$ in case of FGF-2.

- Add $1 \mu \mathrm{g}$ of blank sample and complete up to final volume $20 \mu \mathrm{l}$ of sterile water and mixed well. 
- Incubate $94{ }^{\circ} \mathrm{C}$ for $5 \min , 35$ cycles of $94^{\circ} \mathrm{C}$ for $1 \mathrm{~min}, 55^{\circ} \mathrm{C}$ for $1 \mathrm{~min}, 72^{\circ} \mathrm{C}$ for $1 \mathrm{~min}$. and a single cycle at $72^{\circ} \mathrm{C}$ for $7 \mathrm{~min}$ in case of VEGF and GAPDH.

- Incubate $94{ }^{\circ} \mathrm{C}$ for $2 \mathrm{~min}, 50$ cycles of $94{ }^{\circ} \mathrm{C}$ for $30 \mathrm{~s}, 60^{\circ} \mathrm{C}$ for $30 \mathrm{~s}, 72^{\circ} \mathrm{C}$ for $1 \mathrm{~min}$ and a single cycle at $72^{\circ} \mathrm{C}$ for $5 \mathrm{~min}$. in case of FGF-2.

- At the end of cycles programmed at $4^{\circ} \mathrm{C}$.

\subsection{DNA electrophoresis in agarose gel with ethidium bromide}

To view the products obtained by PCR is necessary to observe in an agarose gel with ethidium bromide, confirming its size and compare them with a marker. Ethidium bromide is mutagenic and carcinogenic and therefore must avoid inhaling the vapors and must be handled with gloves.

\section{Materials:}

- TAE buffer solution.

- Agarose (A9539, Sigma).

- Microwave.

- Ethidium bromide (161-0433, Bio-Rad).

- Loading buffer.

- Molecular marker (1Kb Plus DNA Ladder).

- Transilluminator UV, BioDoc-It System.

- Template cDNA

\section{Procedure:}

- Take $60 \mathrm{ml}$ of TAE buffer solution and add $0.6 \mathrm{~g}$ agarose and heated in a microwave for two minutes for preparing the gel.

- Cool the gel up to $50^{\circ} \mathrm{C}$ and add $0.5 \mu$ l ethidium bromide and shake it until dissolved.

- Pour into the tray and place the molds to form the wells.- Put in a vial $10 \mu \mathrm{L}$ of the sample and add $4 \mu 1$ loading buffer.

- In the first well pour $2.5 \mu \mathrm{l}$ of molecular marker (1Kb Plus DNA Ladder) and 2.5 loading buffer.

- Place in each well in the agarose gel so that the wells are in the negative pole of the tank and the DNA can migrate toward the positive pole.

- Allow to run the samples to a voltage between 40 and $120 \mathrm{~V}$-Display the result of electrophoresis on a transilluminator UV and take a photo from gel. 


\subsection{Life cycle of Schistosoma mansoni in laboratory}

A strain of S. mansoni was maintained by laboratory passage in Biomphalaria glabrata snails and BALB/C strain mice (Cheever et al., 2002). Snails were kept in glass recipients with dechlorinated tap water and fed fresh lettuce ad libitum (Freire et al., 2002). Cercarial shedding was induced phototropically at $30^{\circ} \mathrm{C}$ and the parasites used for infection within three hours of emergence. Anaesthetized mice were infected with cercariae administered on a shaven abdomen and worms were subsequently perfused through an incised portal vein (Doenhoff et al., 1978). Count eggs in the liver and small intestine of infected mice according to Cheever et al., (2002)

\subsubsection{Infection of snails}

\section{Materials}

- Livers of mice infected at 7 week of infection.

- Homogenizator.

- Sedimentation cup.

- Saline solution: $8.5 \mathrm{~g} \mathrm{NaCl}$ in a 11 of destilled water.

\section{Technique:}

- Fragment and homogeneize the liver tissue in saline solution.

- Add up to one liter of water and leave it for $20 \mathrm{~min}$ at $4^{\circ} \mathrm{C}$ in darkness and remove foam and detritus.

- Perform other more sedimentation as above.

- Leave only $50 \mathrm{ml}$ mineral water at the bottom of the sedimentation cup at $25-28^{\circ} \mathrm{C}$ and light

- Expose every snail with 7 miracidia

- Mainain the snails at $24-28^{\circ} \mathrm{C}$ during 4 weeks, then the snail put in light and $28^{\circ} \mathrm{C}$ for cercariae hatching for $2 \mathrm{~h}$.

- Count three times for establish the average individual dosis

\subsubsection{Infection of mice}

\section{Materials}

- Adhesive tape

- Anestesia (Ketamin 100-200 mg/kg and diazepam $5 \mathrm{mg} / \mathrm{kg}$ with atropine $40 \mu \mathrm{g} / \mathrm{kg}$ ).

- Plastic ring.

\section{Technique:}

- Injecte $100 \mu \mathrm{l}$ of the anesthesic mixture.

- Place the ring on the shaved abdomen.

- Administrate $150 \pm 10$ cercariae in $1 \mathrm{ml}$ maximum.

- Leave the darkness mice for 45 minutes. 


\subsubsection{Perfusion of mice:}

\section{Materials}

- Mice infected with 150 cercariae of S. mansoni.

- Scissors, tweezers.

- Syringe and needle $(0.5 \mathrm{~mm})$.

- Heparin saline.

- Pentobarbital sodium, solution.

- Potassium hydroxide 5\%.

- McMaster chamber.

\section{Technique}

- Anesthetize with sodium pentobarbital.

- Cut and remove skin of the abdomen and access to the abdominal cavity.

- Open the chest and inject heparin salin in the left ventricle.

- Cut the portal vein to $0.5 \mathrm{~cm}$, collect and count the worms.

- Remove the liver and weigh it and immerse it in $50 \mathrm{ml}$ of potassium hydroxide, incubate $18 \mathrm{~h}$ a $37^{\circ} \mathrm{C}$ and then count eggs per gram in a McMaster chamber.

\subsection{Adult worm antigens from S. mansoni (AWASm).}

Adult worm antigens (AWASm) from S. mansoni were made in accordance with Dunne et al. (1997).

\section{Materials:}

- Adult worm of Schistosoma mansoni.

- Liquid nitrogen.

- Mortar and paste.

- Proteases inhibitors [1mM N-Tosyl-1 phenylalanine chloromethyl ketone and phenylmethylsulphonyl fluoride (PMSF)].

- Sterile filter with $0.22 \mu \mathrm{m}$.

\section{Procedure:}

- Recovered S. mansoni from the portal perfusion.

- Wash the worms to be free of erythrocytes and submerge them in liquid nitrogen immediately.

- All the worms ground into a paste, and centrifuge them at $10.000 \mathrm{~g}$ at $4^{\circ} \mathrm{C}$ for $1 \mathrm{~h}$.

- Add proteases inhibitors (1mM of N-tosyl-1 phenylalanine chloromethyl ketone, $1 \mathrm{mM}$ of phenylmethylsulphonyl fluoride PMSF).

- Centrifuge the soluble material and filtered through a $0.22 \mu \mathrm{m}$ sterile filter.

- Determination of protein concentration by Micro BCATM Assay.

- Store at $-80^{\circ} \mathrm{C}$. 


\subsection{Cercarial antigen of Schistosoma mansoni (CSm).}

Cercarial antigen (CSm) from S. mansoni was used accordance with Dunne et al. (1997).

\section{Materials:}

- Cercariae of S. mansoni.

- Liquid nitrogen.

- Proteases inhibitors [1mM N-Tosyl-1 phenylalanine chloromethyl ketone and phenylmethylsulphonyl fluoride (PMSF)].

- Sterile filter with $0.22 \mu \mathrm{m}$

\section{Procedure:}

- Recovered and harvest the cercariae of S. mansoni from intermediate host (infected snail).

- Submerge them in liquid nitrogen immediately.

- Sonicate, and centrifuge them at $10,000 \mathrm{x} g$ at $4{ }^{\circ} \mathrm{C}$ for $1 \mathrm{~h}$.

- Add proteases inhibitors (1mM of N-Tosyl-1 phenylalanine chloromethyl ketone, $1 \mathrm{mM}$ of PMSF).

- Centrifuge the soluble material and filtered through a $0.22 \mu \mathrm{m}$ sterile filter.

- Determination of protein concentration by Micro BCATM Assay.

- Store at $-80^{\circ} \mathrm{C}$.

\subsection{Life cycle of Strongyloides venezuelensis in laboratory}

The third stage infective larvae (L3) of S. venezuelensis were obtained from the strain that is maintained at the Laboratory of Parasitology, Faculty of Pharmacy University of Salamanca by serial passage in Wistar rats. This line comes from the Laboratory of Taxonomy and Biology of Invertebrates, Department of Parasitology (Federal University of Minas Gerais, Belo Horizonte, Brazil) and was yield by Professor Alan L. de Melo.

The cycle was performed in accordance with the technique of Martins et al. (1999), where from feces of infected animals recovering eggs of $S$. venezuelensis, to allow the development of these larvae of first (L1), second (L2) and third stage (L3). Feces were mixed with an inert substrate composed of vermiculite. After incubation at $28^{\circ} \mathrm{C}$ for at least $72 \mathrm{~h}$, the L3 collected by a Baermann technique (Rugail et al., 1954). This technique is based on thermo-hydrotropism parasitic characteristic of this phase (Figure 5.1.) Larvae 3 were counted and confirmed that at least $80 \%$ of worm have mobility. Finally 3.000 L3 in $0.5 \mathrm{ml}$ saline solution or PBS sterile was injected subcutaneously to male rats of $60-120 \mathrm{~g}$ (Figures 5.1 and 5.2). 


\section{Materials:}

- L3 of S. venezuelensis.

- Wistar rat (100-150g).

- Vermiculite. (Termite, Asfaltex, Sant Cugat Del Valles, Spain)

- PBS.

- Polycarbonate cages.

- Wire mesh.

- Funnel-size according to need

- Funnel stand

- Clamp or spring clip

- Cheesecloth or dental napkin

- Thin stick or metal rod

- Strainer

- Microscope

- Test tube $12 \mathrm{ml}$

- Pasteur pipette

- Small Petri dishes

- Scissors

- Disposable paper towels

- Spoon or spatula

- Rubber band or length of string

- Jug or flask

- Microscope slides and coverslips

\section{Procedure:}

- Place the infected animals in cages on the grid. Basically it was necessary to filter paper moistened to prevent desiccation of the feces.

- Collect and mix the feces of 24 hours with $20 \mathrm{ml}$ of distilled water and vermiculite in sufficient quantity to maintain saturation of moisture and good aeration and incubate 3-7 days at $28{ }^{\circ} \mathrm{C}$ with relative humidity above $80 \%$.

- To infect male Wistar rats subcutaneously (sc) with third stage larvae of S. venezuelensis.

- Rats keep in polycarbonate cages that have wire mesh with opening of $0.5 \mathrm{~cm}^{2}$ is placed 2 centimeters from the bottom.

- Place some vet papers on the bottom of the cage to keep the faeces moist.

- Collect the faeces after 48-72 hours.

- Mix and homogenize well faeces with vermiculites.

- Incubate coprocultures 3-5 days at $28^{\circ} \mathrm{C}$ and $90 \%$ humidity.

- Place a double layer of cheesecloth or dental napkin on a disposable paper towel or equivalent on bench.

- Using a spoon or spatula weigh or measure approximately 5-10 g of faecal material. Then place faecal material in the centre of the cheesecloth (1).

- Form a pouch containing the faecal material by holding the four corners of the cheesecloth together and moulding the cloth around the faecal material $(2,3$, and 4$)$.

- Using a rubber band or length of string close the cheesecloth pouch and then push the stick or short metal rod under the rubber band or string so that the pouch can be worms suspended $(5,6)$. 
- Place the pouch containing the faecal material in the funnel and trim off the excess cheesecloth (7).

- Fill the funnel with lukewarm water $\left(42^{\circ} \mathrm{C}\right)$ and make sure the faecal material is well covered $(8,9)$ and leave the apparatus to stand for $45 \mathrm{~min}$.

- Draw off a few millilitres of fluid from the stem of the funnel into a test tube, and then either leave to sediment for at least 30 minutes or the fluid can be drawn into a centrifuge tube and spun at $1000 \mathrm{rpm}$ for 2 minutes.

- Check sediment sample in a Petri dish for the presence of larvae and collect larvae (L3) of $S$. venezuelensis, count them and consider motility and morbidity.

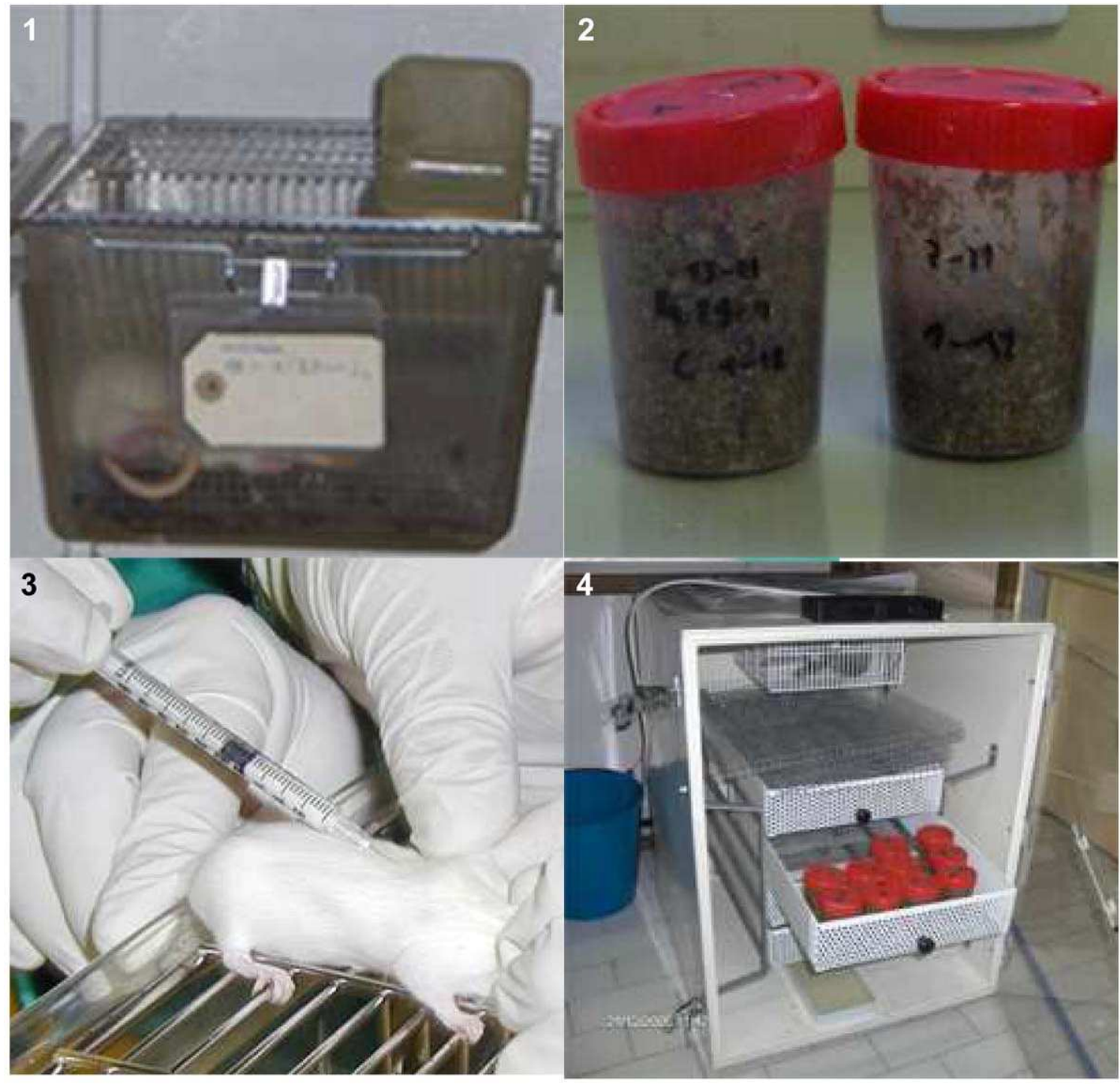

Figure 5.1: Biological cycle of S. venezuelensis in the laboratory. Obtention of feaces from rats infected (1). Coporcultures (2). Subcutaneous infection (3). Incubator at $28^{\circ} \mathrm{C}$ and more than $85 \%$ or relative humidity.. 

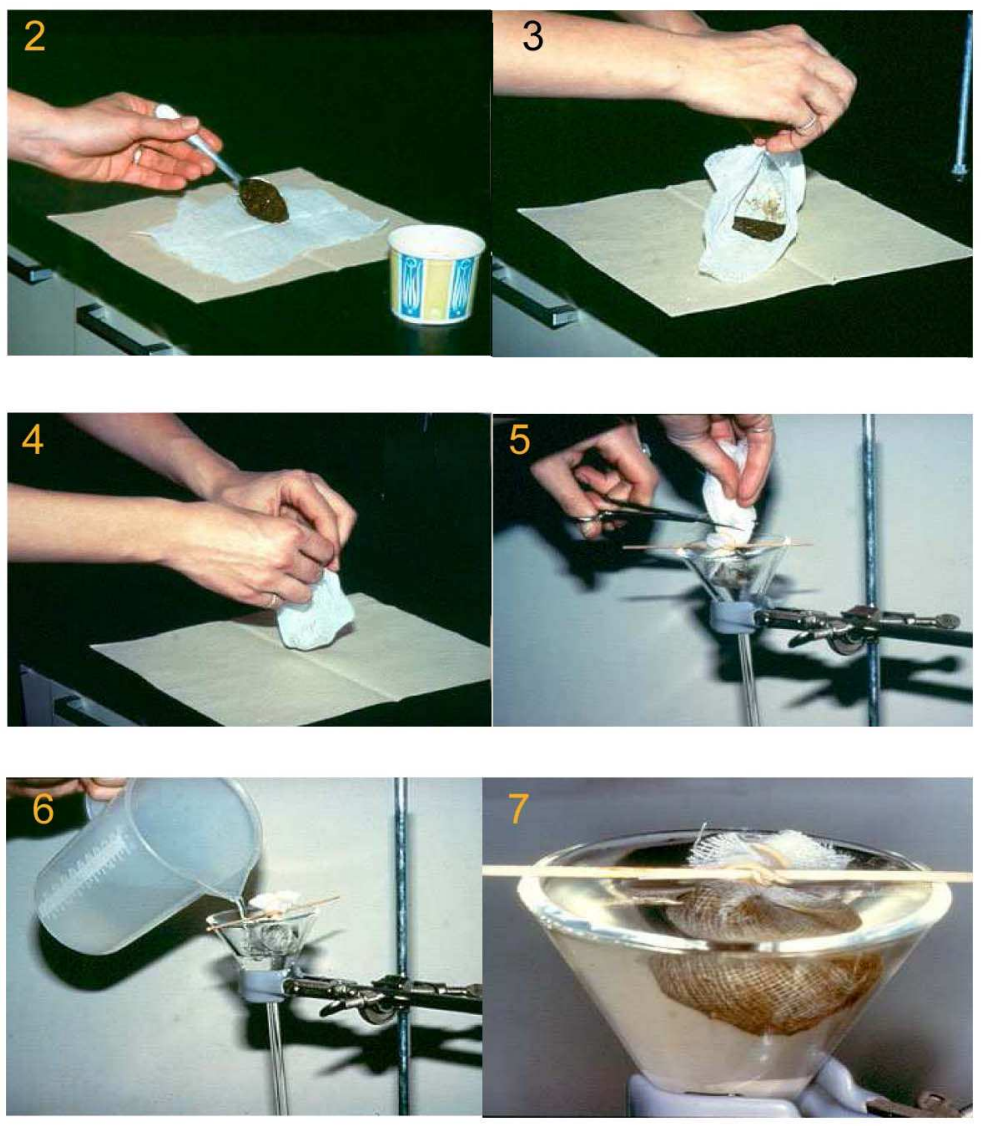

Figure 5.2 The Baermann technique is based on the active migration or movement of larvae. Baermann apparatus (1). Faeces are plased on 8 layer of gauze (2), to enveloped $(3,4)$, then placed in the Baermann apparatus (5) and finally water at $42-44^{\mathrm{a}} \mathrm{C}$ is poured. Faeces are moisted by the water, larvae moved into and we can collect them. 


\subsection{Decontamination of larvae and female adult of $S$. venezuelensis}

Third stage of larvae and female adult of S. venezuelensis decontaminate according to Martins et al. (2000). Larvae and parthenogenetic females of S. venezuelensis obtained from stool culture and necropsy didn't have sufficient features to be cultivated because microbial flora of the environment in which they were obtained, could contaminate the culture media. For all this, because to remove these contaminating organisms larvae and females of S. venezuelensis processed with sodium hypochlorite, antibiotics and antifungal in sterile distilled water.

\section{Materials:}

- Third stage larvae of S. venezuelensis

- Female adult of S. venezuelensis

- PBS sterile

- Sodium hypochlorite $0.25 \%$ (212297, Panreac).

- Sterile distilled water

- Sodium benzylpenicillin $180 \mu \mathrm{g} / \mathrm{ml}$

- Ceftazidime $1.0 \mathrm{mg} / \mathrm{ml}$

\section{Procedures:}

- Wash larvae and adults with sterile distilled water

- Treated with sodium hypochlorite $0.25 \%$ for $10 \mathrm{~min}$

- Wash with sterile distilled water

- Exposed larvae and adults to Sodium benzylpenicillin $180 \mu \mathrm{g} / \mathrm{ml}$ and Ceftazidime 1.0 $\mathrm{mg} / \mathrm{ml}$ for 30-60 $\mathrm{min}$

- Wash with sterile distilled water

- Store at -80

\subsection{Necropsy of mice infected with Strongyloides venezuelensis.}

Necropsy was performed to obtain larvae from lungs or adults from the intestine (Vlaminck, 2010)

\section{Materials}

- Scissors, tweezers

- Saline solution: $8.5 \mathrm{~g} \mathrm{NaCl}$ in a 11 of destilled water.

- Sedimentation cup

\section{Technique:}

- Sacrifice mice with cervical dislocation

- Remove skin from the abdominal region and open the intestinal cavity.

- Remove the upper $2 / 3$ of the small intestine, cut open it longitudinally, and incubate in PBS at $37^{\circ} \mathrm{C}$ for $2 \mathrm{~h}$. 
- Remove the lungs, fragmente in PBS, and incubate for $2 \mathrm{~h}$ at $37^{\circ} \mathrm{C}$.

- Quantificate under stereo microscopy worms that emerge from each organ.

\subsection{Obtanining different antigens from third stage of larvae (L3) and female parthenogenetic from $S$. venezuelensis.}

Preparation of PBS-soluble extract antigen (L3-PBS) and excretory secretory of L3 from S. venezuelensis were done as described Conway et al. (1994). We obtained a total of eight proteins and metabolic products extracts from L3 and parthenogenetic females of S. venezuelensis.

\subsubsection{Soluble antigen preparation from $S$. venezuelensis L3 (L3-PBS).}

The soluble antigen in phosphate buffer solution (PBS) of L3 larvae of S. venezuelensis was obtained after various processes including: freezing / thawing, homogenization and application of ultrasonic. This procedure was performed in a solution containing protease inhibitors (Conway et al., 1994).

\section{Material:}

- PBS sterile

- Third stage larvae of S. venezuelensis

- Protease inhibitors: (5mM ethylendiaminetetraacetic acid (EDTA), 2mM phenylmethylsulphonyl fluoride (PMSF)), $1 \mu \mathrm{M}$ pepstatin, $4 \mu \mathrm{M}$ aproptinin and $10 \mu \mathrm{M}$ chymostatin)

- $\mathrm{NaOH} 0.15 \mathrm{M}$

- Syringe filter (Millipore) with $0.2 \mu \mathrm{m}$ pore size

- Dulbecco-modified Eagle's Medium (DMEM)

- Ethylenediaminetetraacetic acid (EDTA) in distilled water 1M (E-9884, Sigma).

- Phenilmethysulfonylfluoride (PMSF) 0.33 M in ethanol (P-7626, Sigma).

- Chemostatina in water (C-7268, Sigma).

- Aprotinin in $0.9 \% \mathrm{NaCl}$ saline (A-6012, Sigma).

- 1M pepstatin A in ethanol. (P4265. Sigma).

- Phosphate buffer solution (PBS) $0.14 \mathrm{M} \mathrm{NaCl}, 2.7 \mathrm{nM} \mathrm{KCl}, \mathrm{KH} 2 \mathrm{PO} 41.5 \mathrm{~nm}$, $\mathrm{Na} 2 \mathrm{HPO} 46.5 \mathrm{nM}$.

- Sodium hydroxide 0.01 M (621845, Panreac).

- Hydrochloric acid 1 M (181021, Panreac).

- Semi-permeable membranes of cellophane.

- Kit BCA protein determination: Micro BCA Protein Assay Kit (23235 Pierce).

- Glass Homogenizer.

- Sonicator.

- Centrifuge.

- Chamber cold at $4{ }^{\circ} \mathrm{C}$.

- Shaker with thermostat. 


\section{Procedure:}

- Wash larvae with sterile distilled water

- Decontamination of larvae (Martins method)

- Resuspended L3 at a concentration of approximately $2 \times 10^{5} / \mathrm{ml}$ in PBS with 5mM EDTA, 2mM PMSF and Aproptinin $100 \mathrm{IU} / \mathrm{ml}$, Pepstatin A $1 \mu \mathrm{M}$ and Chemostin $1 \mathrm{mM}$.

- Homogenize the suspension in ice-water bath 30-60 minutes.

- Subsequently sonicate the suspension 8 times for 20 seconds at $70 \mathrm{kHz}$.

- Incubate $1 \mathrm{hr}$ at $4^{\circ} \mathrm{C}$

- Centrifuged at $13,000 \mathrm{~g}$ for 30 minutes at $4{ }^{\circ} \mathrm{C}$.

- Collect the supernatant and store at $-80^{\circ} \mathrm{C}$.

- Determine the protein concentration in the supernatant by Micro BCA TM Assay.

- Check the bands in a polyacrylamide gel with sodium dodecyl sulfate (SDS-PAGE) to $12.5 \%$ stained with Coomassie blue.

\subsubsection{Alkaline extraction of adult female antigen of $S$. venezuelensis (F-ALK)}

This extract is obtained by exposing adult female worm of $S$. venezuelensis in an isotonic solution alkalinized with sodium hydroxide according to Machado et al. (2003) and Faccioli et al. (2003).

\section{Material:}

- PBS sterile.

- Female adult worm of $S$. venezuelensis.

- Protease inhibitors: (5mM ethylendiaminetetraacetic acid (EDTA), 2mM phenylmethylsulphonyl fluoride (PMSF)), $1 \mu \mathrm{M}$ Pepstatin, $4 \mu \mathrm{M}$ Aproptinin and $10 \mu \mathrm{M}$ chymostatin).

- $\mathrm{NaOH} 0.15 \mathrm{M}$.

- Syringe filter (Millipore) with $0.2 \mu \mathrm{m}$ pore size.

- Dulbecco's modified Eagle's medium (DMEM, D-0819 Sigma).

- Ethylenediaminetetraacetic acid (EDTA) in distilled water 1M (E-9884, Sigma).

- Phenilmethysulfonylfluoride (PMSF) 0.33 M in ethanol (P-7626, Sigma).

- Chymostatin in water (C-7268, Sigma).

- Aprotinin in $0.9 \% \mathrm{NaCl}$ saline (A-6012, Sigma).

- Pepstatin A in ethanol 1 M (P4265, Sigma).

- Phosphate buffer solution (PBS) $0.14 \mathrm{M} \mathrm{NaCl}, 2.7 \mathrm{nM} \mathrm{KCl}, \mathrm{KH}_{2} \mathrm{PO}_{4} 1.5 \mathrm{nM}, \mathrm{Na}_{2} \mathrm{HPO}_{4}$ $6.5 \mathrm{nM}$.

- Sodium hydroxide 0.01 M (621845, Panreac).

- Hydrochloric acid 1 M (181021, Panreac).

- Semi-permeable membranes of cellophane.

- Kit BCA protein determination: Micro BCA Protein Assay Kit (23235 Pierce).

- Glass Homogenizer

- Sonicator

- Centrifuge

- Chamber cold at $4{ }^{\circ} \mathrm{C}$

- Shaker with thermostat 


\section{Procedure:}

- Wash adult female worm with sterile distilled water and decontaminate them subsequently.

- Suspended 1.000 adult worms in $20 \mathrm{ml}$ of PBS

- Add EDTA 5mM, PMSF $2 \mathrm{mM}$ and Aprotinin 100UI/ml, Pepstatin A $1 \mu \mathrm{m}$ and Chymostatin $1 \mathrm{mM}$.

- Add $1 \mathrm{ml}$ of $\mathrm{NaOH} 0.15 \mathrm{M} / 20 \mathrm{ml}$ of suspension of parasite.

- Agitation the suspension slowly at $4^{\circ} \mathrm{C} 6$ hours

- Add 0.3M of HCL (PH 7)

- Sonicate the suspension 8 times for 20 seconds at $70 \mathrm{kHz}$

- Centrifuge at $13,000 \mathrm{~g}$ for $30 \mathrm{~min}$ at $4^{\circ} \mathrm{C}$

- Store supernatant at -80

- Determination of protein concentration by Micro BCA TM Assay and Check the bands in a polyacrylamide gel with sodium dodecyl sulfate (SDS-PAGE) to $12.5 \%$ stained with Coomassie blue.

\subsubsection{Preparation of the excretory/secretory of L3 (L3-ES) antigen form}

\section{S. venezuelensis}

Excretory secretory antigens of third stage larvae of S. venezuelensis are prepared according to Northern and Grove (1990) (L3-ES).L3 S. venezuelensis were kept in distilled water and incubated at $28{ }^{\circ} \mathrm{C}$ with good condition to have sufficient lighting. Due to the low feeding activity of the L3, it is necessary to be cultivated for 5 to 10 days to collect the products of excretion/secretion of the parasite according to Brindley et al. (1988).

\section{Materials:}

- Larvae 3 S. venezuelensis decontaminated.

- Culture flasks $100 \mathrm{ml}$.

- Incubator

\section{Procedure:}

- Resuspended $1500 \mathrm{~L} 3 / \mathrm{ml}$ in $20 \mathrm{ml}$ of PBS with penicillin $100 \mathrm{IU} / \mathrm{ml}$, streptomycin $0.1 \mathrm{mg} / \mathrm{ml}$, fluconazol $0.8 \mathrm{mg} / \mathrm{ml}, 5 \mathrm{mM}$ EDTA, $2 \mathrm{mM}$ PMSF and Aprotinin $100 \mathrm{IU} / \mathrm{ml}$, Pepstatin A $1 \mu \mathrm{M}$ and chymostatin $1 \mathrm{mM}$.

- Place in the incubator at $28^{\circ} \mathrm{C}$ and humidity of $80 \%$.

- Check daily that the larvae are moving. Count was conducted over one hundred mobile L3. If bacterial contamination is detected larvae must be discarding.

- Maintain the cultures until the mobile L3 are 30\%.

- Centrifuge the culture at $1000 \mathrm{~g}, 5$ minutes, and the supernatant collected and lyophilized.

- Weigh the lyophilized and then rehydrate it to obtain a concentration around $1 \mu \mathrm{g} / \mu \mathrm{l}$.

- Determine the protein concentration and check on a SDS-PAGE gel $12.5 \%$ stained with Coomassie blue. Store at $-80^{\circ} \mathrm{C}$. 


\subsubsection{Female excretory/secretory antigens preparation of $S$. venezuelensis.}

Parthenogenetic female of S. venezuelensis once decontaminated, can be maintained in the laboratory for about a week with cell culture media, adding glucose and carbon dioxide atmosphere according to Maruyama and Nawa (1997).

\section{Materials}

- Female parthenogenetic S. venezuelensis decontaminated.

- Dulbecco's modified Eagle's medium (DMEM, D-0819 Sigma).

- Glucose 50\% in PBS.

- Culture flasks $100 \mathrm{ml}$.

- Incubator with $5 \% \mathrm{CO}_{2}$ at $37^{\circ} \mathrm{C}$.

\section{Procedure:}

- Resuspended 30 females/ml in $20 \mathrm{ml}$ PBS with $1 \%$ glucose, penicillin $100 \mathrm{IU} / \mathrm{ml}$, streptomycin $0.1 \mathrm{mg} / \mathrm{ml}$, fluconazol $0.8 \mathrm{mg} / \mathrm{ml}, 5 \mathrm{mM}$ EDTA, $2 \mathrm{mM}$ PMSF and Aprotinin $100 \mathrm{IU} / \mathrm{ml}$, Pepstatin A $1 \mu \mathrm{M}$ and chymostatin $1 \mathrm{mM}$ in cell culture flasks at $37^{\circ} \mathrm{C}$ with $5 \% \mathrm{CO}_{2}$ and $80 \%$ humidity.

- Add sugar daily to maintain a minimum of $1 \%$, check the mobility of 100 females and control contamination with bacteria and other micro organism by Gram's method in the culture medium.

- Remove the culture medium every 3 days until mobility reach below 70\%.

- Centrifuge the culture at $1.000 \mathrm{~g}$ for 5 minutes, recovering the supernatant and freeze it at $-80^{\circ} \mathrm{C}$ and lyophilized.

- Rehydrate the lyophilized protein to obtain an approximate concentration of $1 \mathrm{mg} / \mathrm{ml}$ of antigen.

- Remove the supernatant and store at $-20^{\circ} \mathrm{C}$.

- Determination of protein concentration by Micro BCATM Assay and check the bands in SDS-PAGE gel $12.5 \%$ stained with Coomassie blue.

\subsection{Mc Master egg counting for quantitation of nematode eggs}

Fecal worm egg examination methods are based on the principle of differential density. In other words, parasites eggs sink in water, but they will float in various chemical solutions that are more dense than water because the eggs are lighter than the fluid used as a flotation solution.

\section{Materials:}

- Compound microscope.

- Scale.

- Saturate sodium chloride solution mix water with salt and add more salt then heat the mixture in pan with stirring until boiling. Then let it to cool at room temperature. The solution will look cloudy and some material will precipitate and now it OK. Pour clear part of solution into a dispensing container of dome kind and store at room temperature. Do not refrigerate as additional solute will precipitate. 
- $50 \mathrm{ml}$ centrifuge tube with screw cap.

- Pipet (1 ml syringe or eye dropper works well)

- McMaster egg counting slide.

- Paper towels.

- A fresh fecal sample should be collected and kept refrigerated until tested.

Procedures:

- Weight out $2 \mathrm{~g}$ of feces into a $50 \mathrm{ml}$ centrifuge tube and fill to $30 \mathrm{ml}$ with salt solution.

- Pour off approximately $25 \mathrm{ml}$ of the salt solution into another small container keeping feces in the tube.

- Let soak for a few minutes and mix (soft feces) or break up (fecal pellets) with tongue blade.

- Add back about $1 / 2$ of the salt solution and mix well, breaking up any remaining feces and homogenize feces as best as possible.

- Add back the remaining salt solution and screw the cap back onto the tube.

- Shake tube vigorously for about 1 minute to disrupt any remaining feces as much as possible.

- Set tube aside for a few minutes to let bubbles dissipate.

- Wet McMaster chamber with water and dry top and bottom on paper towels.

- Rock tube several times to thoroughly mix solution without causing large air bubbles to form.

- Pipet immediately (using $1 \mathrm{ml}$ syringe or eye dropper) a sample of the suspension and fill both sides of counting chamber. Work quickly. If it takes more than a few seconds to load the first chamber, then mix fecal solution again and refill pipet before loading the second chamber.

- Let stand for 1-2 minutes to allow eggs to float to top.

- Count all eggs inside of grid areas (greater than $1 / 2$ of egg inside grid) using low power (10x) objective. Focus on the top layer, which contains the very small air bubbles (small black circles, if numerous large air bubbles are visible, remove the fluid and refill)

- Count only trichostrongyle/strongyle eggs (oval shaped, $\sim 80-90 \mu \mathrm{m}$ ). Do not count strongyloides (oval, 50 microns long), tapeworm eggs (triangular/D-shaped) or coccidia (various sizes). Notations are made as to the presence of other species, but only the trichostrongyle/strongyle eggs are counted.

- Once filled, the chambers can sit for no longer than 60 minutes before counting without causing problems. Longer than this and drying/crystal formation begin.

- Total egg count (both chambers) $\times 50=E P G$ (eggs per gram).

\subsection{Enzyme-linked immunosorbent assay (ELISA)}

ELISA is a biochemical technique used mainly in immunology to detect the presence of an antibody or an antigen in a sample. The ELISA has been used as a diagnostic tool in medicine and veterinary as well as a quality control check in various industries. Detection of an experimental Schistosoma mansoni infection in CD1 mice serum the IgG total, IgG1 and IgG2a has done by ELISA technique 


\section{Materials:}

- Microtiter plates of 96-Well.

- Eppendorf tubes.

- Twelve-channel pipettor.

- Adjustable pipettor of $1 \mathrm{ml}$.

- Humid chamber.

- Wash battle or ELISA plate washer.

- Polystyrene microtiter plates (Costar, Cambridge, MA, USA)

- Peroxidase rabbit anti-mouse immunoglobulin G (Sigma).

- Peroxidase monoclonal anti-mouse immunoglobulin G1 and G2a (Nordic immunology)

- Plate reader.

- TMB.

- Carbonate buffer.

- Wash buffer.

- Blocking buffer.

\section{Procedures:}

- Coate plates with $100 \mu \mathrm{l}$ of either S. mansoni AWA per well at a previously determined protein concentration of $5 \mu \mathrm{g} / \mathrm{ml}$ diluted in carbonate buffer $\mathrm{pH} 9.6$.

- Place serum at a dilution of 1:100 was added to the wells.

- Incubate for 1 hour at $37^{\circ} \mathrm{C}$.

- Wash three times with $200 \mu$ l of PBS-Tween 20 per well.

- Add horseradish peroxidase rabbit anti-mouse IgG, IgG1 or IgG2a at a dilution of $1: 1.000$.

- Wash three times with $200 \mu$ l of PBS-Tween 20 per well.

- Incubate for 1 hour at $37^{\circ} \mathrm{C}$, with substrate solution ortho-phenylene diamine plus $\mathrm{H}_{2} \mathrm{O}_{2}$

- Stop the reaction at 10 minutes with $3 \mathrm{~N}$ of $\mathrm{H}_{2} \mathrm{SO}_{4}$.

- Read absorbances at $492 \mathrm{~nm}$

\subsection{References}

Andrade MA, Siles-Lucas M, Lopez-Aban J, Nogal-Ruiz JJ, Perez-Arellano JL, MartinezFernandez AR, et al., 2007. Trichinella: differing effects of antigens from encapsulated and non-encapsulated species on in vitro nitric oxide production. Vet Parasitol 143:8690.

Brindley PJ, Gam AA, Pearce EJ, Poindexter RW, Neva FA, 1988. Antigens from the surface and excretions/secretions of the filariform larva of Strongyloides stercoralis. Mol Biochem Parasitol 28: 171-80

Cheever AW, Lenzi JA, Lenzi HL, Andrade ZA, 2002. Experimental models of Schistosoma mansoni infection. Men Inst Oswaldo Cruz 97: 917-940 
Conway DJ, Lindo JF, Robinson RD, Bundy DA, Bianco AE, 1994. Strongyloides stercoralis: characterization of immunodiagnostic larval antigens. Exp Parasitol; 79: 99105

Doenhoff M, Bickle Q, Long E, Bain J \& McGregor A, 1978. Factors affecting the acquisition of resistance against Schistosoma mansoni in the mouse. I. Demonstration of resistance to reinfection using a model system that involves perfusion of mice within three weeks of challenge. Journal of Helminthology 52, 173-186

Dunne DW, Webster M, Smith P, Langley JG, Richardson BA, Fulford AJC, Butterworht AE, Sturrock RF, Kariuki HC, Ouma JH, 1997. The isolation of 22 kDa band after SDSPAGE of Schistosoma mansoni adult worms and its use to demonstrate that IgE responses against the antigen(s) it contains are associated with human resistance to reinfection. Parasite Immunol 19: 79-89

Espinoza E, Muro A, Martin MM, Casanueva P, Perez-Arellano JL, 2002. Toxocara canis antigens stimulate the production of nitric oxide and prostaglandin E2 by rat alveolar macrophages. Parasite Immunol 24:311-9

Freire N, Machado Silva JR, Rodrigues-Silva R, Rey L, 2002. Cercarial chaetotaxy and sex differentiation of Schistosoma mansoni deriving from humans and Nectomys squamipes (Muridae: Sigmondontinae) in Brazil. Mem Inst Oswaldo Cruz 97:127-132

Kiemer AK, Vollmar AM, 1997. Effects of different natriuretic peptides on nitric oxide synthesis in macrophages. Endocrinology 138:4282-90

Machado ER, Ueta MT, Gonçalves-Pires MR, Alves de Oliveira JB, Faccioli LH, CostaCruz JM, 2003. Strongyloides venezuelensis alkaline extract for the diagnosis of human strongyloidiasis by enzyme-linked immunosorbent assay. Mem Inst Oswaldo Cruz 98: $849-51$

Martins WA, Melo AL, Nicoli JR, Cara DC, Carvalho MA, Lana MA, Vieira EC, Farias LM, 2000. A method decontaminating Strongyloides venezuelensis larvae for the study of strongyloidiasis in germ-free and conventional mice. J Med Microbiol 49: 387-90

Northern C, Grove DI, 1990. Strongyloides stercoralis: antigenic analysis of infective larvae and adult worms. Int J Parasitol; 20: 381-7

Nurkiewicz TR, Porter DW, Barger M, Castranova V, and Boegehold MA, 2004. Particulate Matter Exposure Impairs Systemic Microvascular Endothelium-Dependent Dilation. Environ Health Perspect 112: 1299-1306. 
Porter DW, Hubbs AF, Mercer R, Robinson VA, Ramsey D, McLarurin J, Khan A, Battelli L, Brumbaugh K, Teass A., et al. 2004. Progression of lung inflammation and damage in rats after cessation of silica inhalation. Toxicol Sci 79, 370-380.

Smithers SR, Terry RJ, 1965. The infection of laboratory hosts with cercariae of Schistosoma mansoni and the recovery of the adult worms. Parasitology 55:695-700

Vlaminck J, López Abán J, Ruano AL, del Olmo E, Muro A, 2010. Vaccination against Strongyloides venezuelensis with homologue antigens using new immunomodulators. J Parasitol (in press). 